UNIVERSIDADE DE SÃO PAULO

FACULDADE DE FILOSOFIA, LETRAS E CIÊNCIAS HUMANAS DEPARTAMENTO DE CIÊNCIA POLÍTICA

PROGRAMA DE PÓS-GRADUAÇÃO EM CIÊNCIA POLÍTICA

TERRA FRIEDRICH BUDINI

Encontros com o Mercosul: a atuação de organizações da sociedade civil brasileira na integração regional 


$$
\text { UNIVERSIDADE DE SÃO PAULO }
$$

FACULDADE DE FILOSOFIA, LETRAS E CIÊNCIAS HUMANAS

DEPARTAMENTO DE CIÊNCIA POLÍTICA

PROGRAMA DE PÓS-GRADUAÇÃO EM CIÊNCIA POLÍTICA

TERRA FRIEDRICH BUDINI

\title{
Encontros com o Mercosul: a atuação de organizações da sociedade civil brasileira na integração regional
}

\author{
Versão corrigida da tese apresentada ao \\ Programa de Pós-graduação em Ciência \\ Política do Departamento de Ciência Política \\ da Faculdade de Filosofia, Letras e Ciências \\ Humanas da Universidade de São Paulo, para \\ obtenção do título de Doutor em Ciência \\ Política \\ Orientadora: Profa. Dra. Rossana Rocha Reis
}


Banca Examinadora 


\section{Agradecimentos}

Agradeço em primeiro lugar à Professora Rossana Rocha Reis pela orientação, diálogo, paciência e pela liberdade proporcionada durante este trabalho.

Meus agradecimentos também aos Professores, funcionários e colegas do Departamento de Ciência Política da Universidade de São Paulo, com os quais tive o privilégio de apreender, conviver e tecer novas amizades durante estes quatro anos.

Agradeço ainda aos queridos amigos pelo apoio fraterno de sempre e, finalmente, meu mais profundo agradecimento aos meus pais, por compreender minhas ausências e pelo incansável incentivo. 


\section{Resumo}

O presente trabalho estuda a atuação de organizações da sociedade civil brasileiras no Mercosul por meio de uma dupla estratégia: o uso de repertórios tradicionais de protesto/mobilização social e participação em canais institucionais de diálogo. A revisão da literatura mostra que estas duas dimensões da ação têm sido tratadas de forma fragmentada em grande parte das contribuições teóricas sobre o tema. A partir do estudo da atuação de de organizações da sociedade civil no tema da integração regional, os objetivos deste trabalho são compreender como mobilizam simultaneamente estas duas estratégias e, desta forma, contribuir com o debate na área sobre o transnacionalismo e a influência de atores nãoestatais no campo das Relações Internacionais.

Palavras-chave: sociedade civil; transnacionalismo; participação social; Mercosul; integração regional 


\section{Abstract}

This thesis studies the activities of Brazilian civil society organizations in Mercosur through a dual strategy: the use of traditional repertoires of protest/social mobilization and participation in institutional channels for dialogue. The literature review shows that these two dimensions of action have been treated in a fragmented way in much of the theoretical work on the issue. Based on the activities of social actors in the regional integration process, the goals of this research are to understand how these actors simultaneously mobilize those strategies, and thus to contribute to the debate on transnationalism and the influence of non-state actors in the International Relations field.

Key words: civil society; transnationalism; social participation; Mercosur; regional integration 


\section{Índice}

$\begin{array}{lr}\text { SIGLAS } & 10\end{array}$

INTRODUÇÃO 12

CAPÍTULO I 17

$\begin{array}{ll}\text { Organizações da sociedade civil e instituições internacionais } & 17\end{array}$

Organizações da sociedade civil e o Estado $\quad 39$

Objeto de pesquisa - os encontros entre organizações da sociedade civil e a integração regional no Mercosul $\quad 43$

Hipóteses de trabalho e considerações metodológicas $\quad 47$

CAPÍTULO II $\quad 51$

Acordos de integração regional - do Tratado de Assunção ao fim das

negociações da ALCA 51

Do Tratado de Assunção ao lançamento oficial das negociações da ALCA: mobilização e participação do movimento sindical 58

$\begin{array}{ll}\text { O período de transição e a atuação nos subgrupos de trabalho } & 58\end{array}$

O início da união aduaneira e a criação do Fórum Consultivo Econômico e Social $\quad 65$

Mercosul, ALCA e as mobilizações transnacionais contra o livre comércio $\quad \mathbf{7 4}$

CAPÍTULO III $\quad 83$

O cenário da integração regional a partir de 2005

A criação de novos mecanismos participativos no Mercosul 92

$\begin{array}{lr}\text { Percepções e estratégias das organizações da sociedade civil } & 102\end{array}$

$\begin{array}{ll}\text { A organização autônoma na Cúpula dos Povos do Sul } & 103\end{array}$

$\begin{array}{ll}\text { Participação nos canais institucionais do Mercosul } & 105\end{array}$

$\begin{array}{ll}\text { Desencontros com o Mercosul } & 114\end{array}$

$\begin{array}{ll}\text { Fragilidades das instâncias participativas } & 114\end{array}$

$\begin{array}{ll}\text { Dilemas da autonomia } & 117\end{array}$

$\begin{array}{ll}\text { Um projeto político para o Mercosul } & 119\end{array}$

CAPÍTULO IV 123

O reencontro com as hipóteses de trabalho 123

$\begin{array}{ll}\text { Participação regional e estrutura institucional do Mercosul } & 130\end{array}$

$\begin{array}{ll}\text { Participação institucionalizada e política externa } & 132\end{array}$

$\begin{array}{ll}\text { Mercosul e o regionalismo sul-americano } & 135\end{array}$

$\begin{array}{lr}\text { CONSIDERAÇÕES FINAIS } & 138\end{array}$

$\begin{array}{ll}\text { ANEXOS } & 141\end{array}$

$\begin{array}{ll}\text { REFERÊNCIAS BIBLIOGRÁFICAS } & 146\end{array}$ 


\section{Siglas}

ABIA - Associação Brasileira Interdisciplinar de AIDS

AFL-CIO - American Federation of Labor and Congress of Industrial

Organizations

ALBA - Alternativa Bolivariana para los Pueblos de Nuestra América

ALCA - Área de Livre Comércio das Américas

ASC - Aliança Social Continental

CAN - Comunidade Andina de Nações

CCM - Comissão de Comércio do Mercosul

CCSCS - Coordenadora de Centrais Sindicais do Cone Sul

CEPAL - Comissão Econômica para a América Latina e o Caribe

CGT - Central Geral dos Trabalhadores

CMC - Conselho Mercado Comum

CNA - Confederação Nacional da Agricultura

CNBB - Conferência Nacional dos Bispos do Brasil

$\mathrm{CNI}$ - Confederação Nacional da Indústria

Contag - Confederação dos Trabalhadores em Agricultura

CTA - Central de Trabajadores Argentinos

CUSFTA - Canada-United States Free Trade Agreement

CUT - Central Única dos Trabalhadores

FASE - Federação de Órgãos para Assitência Social e Educacional

FCES - Fórum Consultivo Econômico e Social

Fetraf - Federação dos Trabalhadores em Agricultura Familiar

FoMerco - Fórum Universitário Mercosul

FS - Força Sindical

FSM - Fórum Social Mundial

GATT - General Agreement on Trade and Tariffs

GMC - Grupo Mercado Comum

IBASE - Instituto Brasileiro de Análises Sociais e Econômicas

IDDH - Instituto de Defesa dos Direitos Humanos

IIRSA - Iniciativa de Infraestrutura Regional Sul-Americana 
INESC - Instituto de Estudos Socioeconômicos

MDIC - Ministério do Desenvolvimento Indústria e Comércio Exterior

Mercosul - Mercado Comum do Sul

MRE - Ministério das Relações Exteriores

MST - Movimento dos Trabalhadores Rurais Sem-Terra

MTE - Ministério do Trabalho e Emprego

NAFTA - North American Free Trade Agreement

OIT - Organização Internacional do Trabalho

OMC - Organização Mundial do Comércio

ORIT - Organização Regional Interamericana de Trabalhadores

PACS - Instituto Políticas Alternativas para o Cone Sul

PMSP - Programa Mercosul Social e Participativo

PPT - Presidência Pro Tempore

PT - Partido dos Trabalhadores

REAF - Reunião Especializada de Agricultura Familiar

REBRIP - Rede Brasileira para a Integração dos Povos

REM - Reunião Especializada da Mulher

RMALC - Red Mexicana de Acción contra el Libre Comercio

SGT - Subgrupo de Trabalho

TEC - Tarifa Externa Comum

TLC - Tratado de Livre Comércio

Unasul - União Sul-Americana de Nações 


\section{Introdução}

Este trabalho aborda formas pelas quais diversos atores não-estatais, como sindicatos, movimentos sociais e ONGs, têm se relacionado com o processo de integração regional no Mercosul ao longo de sua existência. O foco na dimensão transnacional deste processo de integração reflete um interesse mais geral nas possibilidades de influência de atores nãoestatais em um campo de estudo que orbita fortemente em torno do Estado-nação e de regimes e organizações formadas por Estados. Desde os anos noventa, uma ampla literatura tem se desenvolvido nas relações internacionais sobre as possibilidades abertas por estes "novos atores", refletindo as várias vertentes teóricas que coexistem na disciplina. Contudo, uma parte significativa desta bibliografia tem tratado o tema a partir de um viés homogeneizante e pouco atento aos variados processos que conectam os planos doméstico e internacional nas ações destas organizações.

Uma série de trabalhos se dedicaram ao tema a partir de perspectivas teóricas e o fizeram tanto numa abordagem de caráter mais normativo em torno das ideias de democracia cosmopolita e do potencial de "democratização" dos mecanismos internacionais de governança -, quanto a partir de vertentes críticas, atentas às várias formas de poder que se manifestam também entre os atores não-estatais e em suas conexões com Estados e organizações internacionais. A explosão de movimentos sociais críticos voltados para temas internacionais na virada do milênio, como o movimento antiglobalização, deu base para discussões atentas aos conflitos que permeiam também a dimensão transnacional e à conexão destes protestos internacionais com o plano nacional, a partir dos efeitos assimétricos dos processos de globalização. 
Além de transitar entre espaços institucionais e extrainstitucionais, ONGs e movimentos sociais também agem simultaneamente nas esferas nacionais e internacionais, desafiando os níveis de análise e a especialização dos estudiosos de RI no plano internacional e das "outras ciências sociais" no plano doméstico. É neste terreno que situam-se os esforços da literatura sobre o novo transnacionalismo que, no encontro entre contribuições das relações internacionais e da sociologia, busca entender a ação coletiva transnacional em sua relação simultânea com os ambientes nacional e internacional.

Com forte influência da abordagem do processo político de Charles Tilly, o transnacionalismo traz para a análise da ação coletiva transnacional as ideias de estruturas de oportunidades políticas, estruturas de mobilização, repertórios de confronto político e a dimensão simbólica com o processo de framing. De forma geral, nas RI os trabalhos analisam normas internacionais (regimes e Ols) como estruturas de oportunidades políticas que interagem com o cenário doméstico, incentivando ou constrangendo a ação coletiva transnacional. Neste sentido, iluminam a conexão entre o conflito político, a ação coletiva de movimentos sociais e o ambiente internacional, seja por meio da internalização de conflitos que têm origem externa (como mobilizações contra instituições econômicas internacionais), seja pela externalização de conflitos domésticos (com a formação de redes transnacionais de ativismo na área de direitos humanos ou meio ambiente, por exemplo).

Por caminhos diversos, uma série de autores reconhecem a coexistência de estratégias de protestos e confronto com a participação em canais oficiais de diálogo (Tarrow, 2005; Sikkink, 2005; Borras, 2008; Smith e Korzeniewicz, 2006; Chase-Dunn e Gills; 2005), mas, pela própria influência da abordagem do processo político - desenvolvida a partir de uma perspectiva macro-histórica de emergência de movimentos sociais em contraposição ao processo de construção do Estado na Europa, via a 
concentração de poderes antes fragmentados - a tendência tem sido iluminar os casos associados a repertórios de confronto mobilizados por setores excluídos das esferas institucionais, em detrimento de repertórios "participativos" dentro do Estado ou de instituições internacionais.

No plano dos estudos nacionais, a atenção à dupla dimensão da ação de movimentos sociais - mobilização social e luta institucional - é mais bem desenvolvida (Dagnino, 2002; Abers e Von Büllow, 2011; Carlos, 2011; Abers, Serafim e Tatagiba, 2014). No entanto, este diálogo é reconhecidamente difícil, já que a literatura sobre instituições participativas se desenvolve no âmbito da ciência política, particularmente no interior da teoria democrática, dissociada da esfera internacional que, no limite, não seria passível de democratização, por não contar com um poder central acima dos Estados. Contudo, ainda que não falemos por ora em democratização, uma série de organizações da sociedade civil contestam na prática a ação internacional de Estados e Ols, não apenas pela pressão sobre seus governos, mas também por meio de articulações transnacionais, que muitas vezes usam táticas de confronto $\mathrm{e}$ simultaneamente participam de canais de diálogo abertos por Estados e/ou instituições internacionais. Este tem sido, por exemplo, o caso do Mercosul, no qual os governos vêm criando mecanismos de participação de organizações da sociedade civil tanto no âmbito regional, quanto na esfera nacional (no caso brasileiro, inspirado no modelo de conselhos existentes em outras áreas de políticas públicas). Desde o início, o Mercosul tem passado por uma série de crises e tentativas de relançamento em diferentes contextos políticos, desde os processos de reforma estrutural e abertura econômica na década de noventa, passando pela ascensão e queda do projeto da ALCA, pela reorientação política dos anos 2000 e pela coexistência com outros projetos regionais, como a Unasul. Estas mudanças têm se refletido nas estratégias de mobilização e participação de organizações da sociedade civil dentro do bloco. 
A partir de uma pesquisa anterior acerca do debate nas RI sobre a emergência da ideia de "sociedade civil global" e de minha experiência profissional na área internacional de um partido político (e com isso a interlocução com articulações internacionais de movimentos sociais, sindicatos e ONGs), a motivação inicial desta pesquisa era compreender um cenário mais matizado e contraditório na "vida real" e, a partir de um estudo de caso, contribuir para esta discussão. O primeiro movimento foi abandonar qualquer premissa de homogeneidade e tentar compreender os diferentes caminhos das várias organizações na integração regional. Neste sentido, conforme será abordado adiante, o uso do termos "organizações da sociedade civil" é simplesmente uma maneira de fazer referência a um conjunto heterogêneo de sindicatos, movimentos sociais e ONGs. Em segundo lugar, foi necessário construir o campo de debate deste trabalho, em torno da literatura do transnacionalismo e de contribuições da ciência política sobre a permeabilidade da interação entre organizações da sociedade civil e Estado, o que será apresentado no primeiro capítulo. Como será visto, particularmente no caso internacional, há uma tendência a lançar luz sobre a ação coletiva transnacional de caráter episódico em torno de coalizões temáticas, em cenários institucionalmente marcados pelo fechamento às demandas dos movimentos sociais. Em diálogo com esta bibliografia, as hipóteses desta tese são que, mesmo em cenários de estruturas de oportunidades políticas percebidas como relativamente permeáveis às demandas das organizações da sociedade civil, a existência de mecanismos de participação podem sustentar a ação coletiva transnacional, constituindo novos atores e temas; e que a recente percepção de declínio da atuação das organizações da sociedade civil no Mercosul não é diretamente fruto da abertura simultânea dos planos nacional e regional, mas reflexo das próprias dificuldades de avanço no do bloco e a coexistência com outras iniciativas regionais. 
As experiências prévias de mobilização e participação na esfera regional são fundamentais para compreender a percepção das organizações da sociedade civil sobre o cenário regional depois do fim das negociações hemisféricas. Dessa forma, o segundo capítulo reconstrói esta dinâmica de mobilização e participação dos atores sociais no Mercosul nos anos noventa - quando a integração era percebida fundamentalmente como um instrumento adicional das políticas de reforma do Estado e abertura econômica por parte das centrais sindicais - e durante as negociações da ALCA, quando a mobilização passou a incluir umas série de movimentos sociais e ONGs numa coalizão hemisférica. A partir disso, o terceiro capítulo mostra como o fim das negociações da ALCA, as tentativas de reorientação do Mercosul e a abertura de novos canais de participação por parte de governos mais sensíveis às reivindicações destas organizações foram percebidas pelas organizações da sociedade civil e modificaram suas estratégias de atuação. Estes dois capítulos são construídos a partir de documentos, entrevistas e trabalhos prévios sobre o tema (Mariano, 2011, sobre a participação sindical no Mercosul; Berrón, 2007, e Von Büllow, 2010, sobre as mobilizações contra a ALCA). Finalmente, o quarto capítulo retoma o diálogo com as perspectivas teóricas, de forma a mostrar que a participação em canais institucionais figura como uma estratégia adicional ao repertório de confronto considerado na literatura, o que pode sustentar a ação transnacional, constituindo novos temas para além das campanhas e dos momentos episódicos de protesto. 


\title{
Capítulo I
}

\section{Organizações da sociedade civil e instituições internacionais}

\begin{abstract}
Uma passeata contra o Mercosul acabou em confronto ontem com a Polícia Militar em Fortaleza (CE). O ato foi dissolvido com bombas de gás lacrimogêneo. A PM calcula que cerca de 3.000 pessoas participavam da passeata. Os organizadores dizem que 5.000 pessoas estavam no ato.(...) Os manifestantes participavam desde as $9 \mathrm{~h}$ de uma concentração, em frente à Universidade Estadual do Ceará, convocada por sete centrais sindicais do Brasil, Paraguai, Argentina e Uruguai, como parte do "Dia Internacional de Luta Pelos Direitos dos Trabalhadores do Mercosul" (Folha de São Paulo, 18 de dezembro de 1996)
\end{abstract}

What we discover in this twilight is how transnational the modern world has always been, even in the high days when the nation-state bounded and bundled most social processes. Rather than a recente offspring of globalizaction, transnationalism appears as a constant of modern life, hidden from a view that was captured by methodological nationalism. (...) The social sciences were captured by the apparent naturalness and givenness of a world divided into societies along the lines of nation-states. (Wimmer e Glick Schiller, 2002:302-304)

Nas últimas décadas, o campo das Relações Internacionais foi agitado por uma série de contestações à sua narrativa de construção como disciplina e ao Estado como seu objeto privilegiado de pesquisa. Como as citações acima sugerem, a movimentação de atores não-estatais no plano internacional passou a ser um foco importante de estudos na área, incorporado por várias perspectivas teóricas. O termo "atores nãoestatais" se refere a um conjunto extremamente amplo, que inclui organizações muito heterogêneas, de empresas multinacionais a grupos terroristas, de minorias étnicas a movimentos sociais. Cada um deste grupos engendra uma série de reflexões a partir de vertentes teóricas diversas. $O$ foco deste trabalho está sobre um subgrupo - ele próprio heterogêneo - integrado por ONGs, movimentos sociais, redes e coalizões transnacionais. 
Variadas correntes teóricas têm buscado incorporar estes "novos atores" em suas reflexões, analisando as possíveis formas de interação e influência sobre o sistema de Estados e Organizações Internacionais (Ols). Dentre estes, destacam-se particularmente os trabalhos sobre a ideia de uma sociedade civil de caráter global/internacional e a agenda de pesquisa em torno do chamado "novo transnacionalismo".

A produção bibliográfica sobre a emergência de uma sociedade civil de caráter global/transnacional foi inicialmente marcada por uma visão bastante normativa ${ }^{1}$, ao situar esta esfera em contraposição ao mercado e aos Estados no sistema internacional (Lipschutz, 1992; Shaw, 1994; Scholte, 2002; Keane, 2003; Kaldor, 2003). Em trabalhos com um enfoque

\footnotetext{
${ }^{1}$ Esta perspectiva se alinha teoricamente a uma vertente bastante disseminada na década de noventa, a partir do trabalho de Cohen e Arato (2000), de situar a sociedade civil como contraponto ao poder politico e à lógica do mercado. Segundo as contribuições da vertente liberal, a emergência de uma sociedade civil em âmbito global poderia potencialmente democratizar o sistema internacional, na medida em que é considerada uma esfera autônoma dos mercados, dos Estados e das organizações internacionais. O foco nas motivações (no caso, inspiradas por valores e princípios) é um dos elementos centrais destas análises no campos das RI. Fundada numa dimensão normativa, seu referencial empírico está na intensificação de processos já em curso: a revolução nas tecnologias de comunicação, informação e transporte - que possibilitaram uma nova organização espacial da produção - também permitiria uma nova organização das relações sociais em âmbito planetário. Estas novas articulações políticas e sociais seriam um contraponto, ou ainda, seriam forças de pressão democrática ao poder dos Estados nacionais e aos mecanismos formais de governança global. Neste contexto, ganha força a ideia de "sociedade civil global", como a variante societal do processo de globalização econômica (Germain e Kenny, 2005: 2). As concepções de orientação liberal cosmopolita sugerem que uma variada gama de atores integrariam este processo: ONGs, grupos de pressão e redes de ativismo, movimentos sociais, movimentos religiosos, entre outras organizações não-estatais. Em comum a estes atores muito diferenciados residiria o fato de não falarem em nome de Estados e governos, não operarem por meios violentos e não serem orientados pelo lucro. De acordo com Keane (2003:8), seria mais adequado usar o conceito como um tipo-ideal como uma construção mental intencionalmente produzida que, embora não seja achada na sua forma "pura" no mundo social, é útil para nomear e esclarecer a variedade de elementos da complexa realidade social. Nesse sentido, a sociedade civil global se refere a: (...) um sistema dinâmico de instituições socioeconômicas interconectadas que se estende pelo planeta e que tem efeitos complexos que são sentidos nos quatro cantos. (...) É um projeto inacabado que consiste em redes elásticas mais ou menos densas, pirâmides e grupos com centro e ramificações de instituições socioeconômicas e atores que se organizam através das fronteiras, com objetivo deliberado de redesenhar o mundo de novas formas. Estes atores e instituições não-governamentais tendem a pluralizar o poder e a problematizar a violência; consequentemente, seus efeitos pacíficos ou "civis" são sentidos por toda parte...(Keane, 2003:8).
} 
mais empírico, a ideia serviu para apontar uma participação crescente de ONGs em organizações internacionais, como as conferências mundiais das Nações Unidas na década de noventa (Friedman et al., 2001), instituições econômicas multilaterais (O'Brien et al., 2000), ou ainda na criação de novas normas internacionais, como o tratado para o banimento de minas terrestres (Price, 1997), que no limite trariam consigo possibilidades de "democratização ${ }^{2}$ " dos mecanismos de governança internacional.

A popularidade do tema e o viés normativo liberal estimularam também uma extensa bibliografia a partir de várias vertentes críticas, das quais se destaca a perspectiva neogramsciana, que compreende esta ideia de uma sociedade civil transnacional como arenas de disputas entre forças sociais hegemônicas e contra-hegemônicas (Cox, 1999; Colas, 2002; Chase-Dunn e Gills; 2005). Neste cenário, acredita-se que a ideia de "sociedade civil global" pode ser mais bem entendida a partir da distinção de duas grandes dimensões de atuação política não-estatal, ou duas esferas distintas de pressão - "de baixo" e "de cima" - , que podem se complementar ou se contrapor. Levanta-se aqui, seguindo a linha neogramsciana que, entre as próprias organizações sócio-políticas que atuam além das fronteiras, seria possível identificar duas dimensões ou duas esferas distintas de pressão: forças sociais contestadoras/contra-

\footnotetext{
2 Dentro da perspectiva de "democratização" do sistema internacional, estes enfoques consideram que o projeto de ativismo global seria a força "de baixo" (bottom-up, no sentido de pressões vindas da sociedade) que, ao lado do projeto da democracia cosmopolita (de caráter mais institucional, ou top-down, visando à reforma das instituições internacionais em coordenação com os Estados, em um sistema de governança em múltiplas camadas) levariam a ordem internacional rumo a um arcabouço jurídico cosmopolita (Held e McGrew, 2002; Kaldor, 2003). Kaldor afirma: (...) of particular importance, in my view, is a growing body of cosmopolitan law, by which I mean the combination of humanitarian law (laws of war) and human rights law (...)This broadening and strengthening of cosmopolitan law, both immediately after the Second World War and in the 1990s, was largely a consequence of pressure from global civil society. (Kaldor, 2003: 590). O ativismo da sociedade civil global ofereceria possibilidades significativas de reduzir a maioria dos déficits democráticos que cresceram nas últimas décadas na governança das relações globais. Para Scholte, esta democratização se daria por meio da amplificação das vozes dos diversos grupos afetados; do papel educativo de atividades públicas; da pluralidade de posições; do aumento da transparência, por meio de pressão; do aumento da prestação de contas, por meio de acompanhamento; e, como resultado dos cinco elementos acima, do aumento da legitimidade (2002:293-295).
} 
hegemônicas e forças dominantes, interessadas na manutenção da ordem hegemônica. Mesmo dentro do mesmo conjunto de forças sociais favoráveis a transformações democráticas, identificam-se posições e interesses distintos, que podem ou não convergir. Percebe-se que estas duas dimensões se encaixariam na observação feita por Robert Cox (1999) sobre o desenvolvimento do conceito de sociedade civil em âmbito doméstico. Ao empreender uma retomada histórica do termo (do pensamento iluminista a Gramsci), Cox afirma que a revisão conceitual revela dois significados justapostos: um processo "de cima para baixo", no qual as forças dominantes constroem uma hegemonia intelectual e cultural; e um processo "de baixo para cima", no sentido de construção contra-hegemônica (Cox, 1999). Deste modo, este espaço político além das fronteiras - chamado por alguns de "sociedade civil global" - deve ser entendido como arenas povoadas por interesses e estratégias diversas. Mesmo dentro de cada arena, coexistiriam forças hegemônicas e contrahegemônicas com interesses e táticas diferenciadas. Cabe acrescentar que esta divisão não seria estreita, ao contrário: as duas dimensões seriam altamente permeáveis $e$, frequentemente, boa parte das organizações atuariam em ambos os sentidos. Mesmo dentro do mesmo conjunto de forças sociais favoráveis a transformações democráticas, identificam-se posições e interesses distintos, que podem ou não convergir. Com efeito, Chase-Dunn e Gills (2005) identificam uma aparente tensão entre, por um lado, os movimentos sociais que lutam contra a globalização (ou por outra globalização) e, por outro, os grupos que apoiam reformas nas atuais instituições para uma governança mais democrática. Apesar da aparente contradição, as estratégias podem ser complementares.

\section{A literatura sobre o novo transnacionalismo}

Um segundo grupo de análises sobre atores não-estatais na política internacional busca entender de forma mais detalhada como organizações 
da sociedade civil (movimentos sociais, ONGs, sindicatos, universidades, entre outras) constituem redes e coalizões transnacionais, por meio das quais se relacionam com e, eventualmente, influenciam Estados e instituições internacionais. Neste sentido, a literatura sobre o transnacionalismo, que se desenvolve na confluência entre a sociologia com atenção à dimensão transnacional da ação coletiva - e as relações internacionais, parece ser um campo mais promissor. Após breve ensaio na década de 1970, a agenda de pesquisa sobre o transnacionalismo renasceu nos anos 1990, com atenção especial ao papel de atores não estatais no contexto dos chamados processos de globalização. Embora a coletânea de Keohane e Nye (1971) tenha sido pioneira na atenção dada a atores não estatais na política mundial, a agenda de pesquisa daquele período pouco avançou na compreensão do papel destes atores, na medida em que estabeleceu uma dicotomia entre as abordagens estadocêntricas e aquelas centradas na sociedade (Risse, 1995). Esta dicotomia foi abandonada nos anos 1990, quando a maioria dos estudos passou a tentar compreender as relações entre os próprios atores não estatais e os governos, no contexto dinâmico de interconexões entre os âmbitos doméstico e internacional.

Uma das principais influências neste debate foi a chamada abordagem do processo político, vinda do estudo dos movimentos sociais que, adaptada às relações internacionais, centra seu foco em como os movimentos percebem as instituições domésticas e internacionais como estruturas de oportunidades políticas e como a interação entre estes planos favorecem ou constrangem as chances de ativismo transnacional (Tarrow, 2005; Sikkink, 2005). Segundo Sikkink, os debates sobre o papel de normas e ideias nas relações internacionais se beneficiam com a inclusão da discussão sobre frames e crenças coletivas da literatura de movimentos sociais, ao passo que o conceito sociológico de estruturas de oportunidades políticas podem ser complementados pela literatura de RI 
que explora a interação dinâmica entre a política doméstica e o sistema internacional (2005:151). Nas palavras da autora:

(...) social movements operate in both a domestic and an international environment: they speak of "multilayered" opportunity structure including a "supranational" layer", or a "multilevel polity," or highlight how international pressures influence domestic opportunity structures (Sikkink, 2005:151)

Segundo Tarrow, estruturas de oportunidades políticas seriam consistent - but not necessarily formal, permanent or national - dimensions of the political environment that either encourage or discourage people from using collective action (Tarrow, 1998: 18). Empiricamente, no âmbito doméstico, as estruturas de oportunidades políticas são analisadas a partir de cinco elementos: a multiplicidade de centros de poder dentro de um regime; a abertura a novos atores políticos; a estabilidade ou instabilidade dos alinhamentos políticos em dado momento; a disponibilidade de aliados influentes; e o grau de repressão ou incentivo às demandas coletivas (Tarrow, 2005: 23). Ou seja, a abertura de oportunidades políticas aos movimentos sociais dar-se-ia por aumento da permeabilidade das instituições políticas e administrativas às reivindicações da sociedade civil, provocadas por crises na coalizão política no poder; por mudanças na interação política entre o Estado e a sociedade, especialmente a redução da repressão a protestos; e pela presença de aliados potenciais (Alonso, 2009:55).

Além das estruturas de oportunidades políticas, outros dois conceitos importantes desenvolvidos no bojo da teoria do processo político são os frames de ação coletiva e os repertórios de confronto político. Frames referem-se a interpretações da realidade, são formas de dar sentido às lutas, por meio da articulação de normas, discursos, símbolos. São quadros interpretativos que simplificam e condensam o "mundo exterior"; com a produção de frames, os movimentos sociais reduziriam a complexidade social, sinalizando injustiças e apresentando-as como 
problemas que requerem mobilização (Snow e Benford apud Alonso, 2009). Repertórios de confronto são um conjunto de rotinas e práticas mobilizadas pelos movimentos em situações concretas e, segundo os autores da teoria do processo político, também refletem uma dimensão cultural e histórica. As variadas formas de ação coletiva disponíveis abaixo-assinados, greves, ocupações, marchas, cúpulas paralelas refletiriam aspectos culturais de um dado momento histórico (McAdam, Tarrow, Tilly, 2009:16; Alonso, 2009)

No plano internacional, o conceito de estruturas de oportunidades políticas tem sido utilizado para analisar como as instituições internacionais tem se tornado foco de mobilizações e reinvindicações. De acordo com Tarrow (2005), as instituições internacionais surgem como o centro de uma sociedade internacional crescentemente complexa, em torno do qual ONGs, movimentos sociais, grupos religiosos, sindicatos e grupos empresariais se agrupam. Estas instituições intervêm em políticas domésticas através de suas regras e tornam-se locais nos quais atores não estatais e Estados podem fazer reivindicações e construir coalizões. Assim como na política doméstica, na qual os Estados são alvo de resistência e pontos centrais do conflito social e da construção de coalizões, os regimes, práticas e instituições internacionais seriam "recifes de corais" num amplo mar de internacionalismo complexo. (2005: 26,27). Desse modo, as organizações e regimes internacionais construídos por Estados para lidarem com os efeitos da interdependência, que Tarrow denomina como internacionalismo complexo ${ }^{3}$, tornam-se potenciais estruturas de oportunidades ou ameaças políticas que serão alvo de formas transnacionais de ativismo.

\footnotetext{
${ }^{3}$ O conceito de "internacionalismo complexo" se assemelha ao que frequentemente chamamos nas RI de governança global (Roseanau e Czempiel, 2000) ou governança complexa (Hurrell, 2007). Nas palavras de Tarrow o internacionalismo complexo seria a dense, triangular structure of relations among states, nonstate actors, and international institutions, and the opportunities this produces for actors to engage in collective action at diferente levels of this system (2005).
} 
Globalization, like early liberalism, is a source of interest, ideology, and grievances. It produces the flows and trans- actions of an interwoven international capitalist economy. Internationalism is the institutional and informal framework within which transnational activism - some of it aimed at globalization but much of it independent of that process - takes shape. In the triangular relations among states, nonstate actors, and international organizations, regimes, and institutions, we find both resistance to globalization and activism of claimants whose claims have little or nothing to do with globalization. Internationalism provides a framework within which transnational activists respond to threats and seize opportunities that empower their activism (Tarrow: 2005: 19)

Embora o autor afirme que as instituições internacionais possam representar novas estruturas de ameaças ou oportunidades políticas, uma parte significativa desta literatura tem foco privilegiado nos processos de resistência, associados a repertórios de confronto como protestos, marchas, em geral fortemente reprimidas por forças policiais, associada aos movimentos antiglobalização, como o emblemático caso dos protestos em Seattle contra a OMC em 1999. Este foco tem como base o papel de instituições internacionais, principalmente econômicas, como o FMI e o Banco Mundial, na divulgação e aplicação de medidas econômicas ortodoxas que levaram à desigualdades crescentes. Campanhas e movimentos transnacionais surgem desta dinâmica, com organização facilitada por novas tecnologias e dão início a repertórios novos, como cúpulas paralelas e boicotes (2005).

Neste novo cenário, Tarrow e Della Porta (2005) propõem uma sistematização dos vários mecanismos presentes nas reações dos movimento sociais que conectam os planos doméstico e internacional por meio de mobilizações. Estas variadas mobilizações poderiam ser agrupadas em quatro formas:

1) Difusão e mudança de escala

Processos de difusão são os mais familiares segundo os autores; se referem à adoção ou adaptação de repertórios, frames ou alvos de ação coletiva ocorrida num determinado local para outros países 
ou regiões. Há inúmeros exemplos domésticos, que podem envolver simultaneamente a mudança de escala de protestos, como a difusão de formas de ação direta não violenta, como o sit-in, no movimento pelos direitos civis nos EUA. A difusão pode ocorrer por conexão deliberada entre ativistas ou de forma indireta. Recentemente, por exemplo, a difusão da ocupação de praças públicas como repertório de ação tem sido recorrente (o movimento na Praça Tahir no Egito, o movimento dos indignados espanhóis na Plaza del Sol, o Occuppy Wall Street, o Ocupa Parque Augusta, entre vários outros)

2) Internalização

A internalização se refere ao desenvolvimento de conflitos de origem externa no território doméstico. Esta origem externa geralmente pode ser verificada no próprio processo de framing, quando por exemplo, protestos contra a austeridade e o desemprego em determinado país se direcionam não apenas ao governo nacional em questão, mas também a instituições internacionais como o FMI ou a União Europeia.

3) Externalização

Diz respeito à transferência de conflitos domésticos para o âmbito internacional. A forma mais conhecida e estudada de externalização se dá com o modelo bumerangue, quando movimentos e ONGs domésticas buscam alianças com ONGs internacionais e organizações da sociedade civil de outros países, de modo a envolver outros Estados e Ols nas reivindicações em questão.

4) ação coletiva transnacional

Os autores definem como campanhas internacionais coordenadas por redes de ativistas contra atores internacionais, outros Estados ou instituições internacionais (Tarrow e Della Porta, 2005:7). Por ora, podemos citar como exemplo a Campanha Continental contra a ALCA, que envolveu centenas de organizações da sociedade civil do continente no início dos anos 2000 e teve como um dos pontos 
altos a organização de plebiscitos populares sobre o acordo hemisférico.

Estes processos de mobilização que conectam os planos doméstico e internacional mostram que as organizações e regimes internacionais podem ser tanto alvo de protesto contra efeitos nocivos da globalização, como potenciais aliados em reivindicações frente ao Estado, por exemplo, com a mobilização de normas internacionais relacionadas aos direitos humanos ou ao meio ambiente por parte de ONGs e movimentos sociais. Em uma série de trabalhos, Sikkink avança nesta compreensão:

\begin{abstract}
Most authors writing about transnational opportunity structures see international institutions as targets or constraints, not as opportunities or arenas for social movement activity (...) From a theoretical point of view, and thinking about the whole universe of possible transnational contention, however, transnational opportunity structures, just like domestic opportunity structures, need to be seen as presenting both threats and opportunities (...) I believe that social movement theorists will find it useful to take international institutions more seriously as actual arenas for social movement activity, not just as targets. Social movements may sometimes be capable of transforming opportunity structures at the international level and of using international institutions to change domestic opportunity structures (Sikkink, 2005:151,152)
\end{abstract}

É sobretudo neste sentido que Sikkink e Keck (1998), Sikkink (2002; 2005) Risse (1995), Sikkink e Risse (1999) e outros autores vão olhar inicialmente para as instituições e regimes internacionais: como possíveis estruturas de oportunidades que podem ser mobilizadas para alterar contextos domésticos repressores. Segundo Risse, quanto mais as relações interestatais sejam reguladas por instituições internacionais cooperativas numa determinada área, mais as atividades transnacionais devem florescer e os governos nacionais serão menos aptos a constrangê-las, pois regimes e organizações internacionais tendem a aumentar a disponibilidade de canais que os atores transnacionais podem usar para alvejar Estados nacionais (Risse,1995:30). 
Com foco nas redes transnacionais de ativismo, Keck e Sikkink mostraram como estas redes agem simultaneamente de forma estratégica e normativa, apresentando suas pautas de modo a torná-las compreensíveis para sua audiência, a atrair atenção, encorajar a ação e alterar ambientes institucionais. (Keck e Sikkink, 1998:2,3). As autoras vão além de Risse ao identificarem o papel de regimes e normas não como uma estrutura estática, mas sim dinâmica de interação entre Ols, regimes, Estados e atores não estatais, numa constante constituição mútua de identidade, normas e interesses (1998: 34,35). Em texto posterior, as normas figuram claramente como oportunidades políticas no âmbito internacional, que podem ser percebidas, criadas ou alteradas por redes, coalizões e movimentos sociais transnacionais (Sikkink, Khagram e Riker, 2002).

Estes desenvolvimentos iniciais foram construídos em torno de contextos nos quais organizações da sociedade civil conseguiram alterar um cenário doméstico pouco aberto às demandas sociais, por meio da construção de redes transnacionais que mobilizaram normas internacionais (como o regime internacional dos Direitos Humanos) para conseguirem apoio externo e pressionar o Estado originalmente repressor, o que constitui a descrição clássica do padrão bumerangue. Nestes eventos, ao contrário dos casos de mobilização contra instituições econômicas internacionais, a principal relação de conflito se dá com o próprio Estado e o internacional fornece a abertura para a emergência de redes transnacionais por meio de normas e regimes.

De forma a incluir estes diferentes cenários de ativismo, em capítulo publicado em 2005, Sikkink retoma o tema da interação entre estruturas de oportunidades políticas domésticas e internacionais para além da combinação entre estrutura doméstica restrita e internacional favorável do padrão bumerangue, de modo a sistematizar todos os cenários possíveis, o que amplia as possibilidades de se pensar a emergência de atores e relações transnacionais em contextos diversos. 
Para explorar os padrões de interação, a autora foca em um aspecto da estrutura de oportunidade política: o nível de acesso a instituições, ou seja, o quanto instituições são abertas ou fechadas às pressões e à participação de movimentos sociais. Sikkink ressalta que o grau de abertura ou fechamento das instituições internacionais é relativo, na medida em que atores o comparam às instituições domésticas (2005:158). Feitas estas considerações, a autora identifica quatro combinações entre estruturas domésticas e internacionais, que podem sugerir probabilidades de ativismo transnacional, bem como o tipo e o foco de tais ações. Quando ambas as estruturas de oportunidade políticas são percebidas como fechadas e restritas, as chance de ativismo não seriam impossíveis, mas bastante diminuídas. No caso de acesso restrito a instituições domésticas e abertura internacional, teríamos o já mencionado padrão bumerangue e o modelo espiral, no qual poderíamos incluir diversas campanhas transnacionais no tema de direitos humanos. Na configuração oposta, ou seja, quando atores percebem estruturas domésticas mais acessíveis e fechamento de instituições internacionais, teríamos o que Sikkink define como transnacionalismo defensivo, no qual a ação coletiva transnacional visa minimizar possíveis perdas, mais que assegurar ganhos (um exemplo seria a coalizão transnacional formada contra o livre comércio nas Américas). Finalmente, quando ativistas enxergam a abertura de ambas as estruturas de oportunidade, tenderiam a privilegiar o doméstico, mantendo o ativismo internacional como estratégia complementar, num modelo de coalizão insider-outsider que, segundo a autora, seria o cenário menos explorado na literatura e menos previsível. Portanto, com exceção deste último cenário colocado por Sikkink, todos os outras apresentam instituições com acesso restrito ou pouco permeável aos atores da sociedade civil pelo menos em um dos planos de atuação, seja o doméstico ou o internacional. 
Estes variados cenários dão origem a novos formatos de organização e de ação coletiva em âmbito transnacional. Para além das campanhas (Tarrow e Della Porta, 2005:7), Sikkink, Khagram e Riker identificam outras formas de ação: redes transnacionais de advocacy, coalizões transnacionais e movimentos sociais transnacionais (2002: 6). As redes demandam menos esforços conjuntos, podem ser formais ou informais e caracterizam-se pelo intercâmbio e uso de informação. As coalizões transnacionais por sua vez demandam mais coordenação, pois caracterizam-se pelo compartilhamento de estratégias e táticas para buscar influência pública (as campanhas transnacionais são neste sentido o principal instrumento das coalizões). Finalmente, os movimentos sociais transnacionais envolvem além da coordenação de estratégias, o compartilhamento de identidades e solidariedades que cruzam fronteiras, capazes de gerar mobilização social coordenada e sustentada em mais de um país.

Como mencionado, o conceito de estruturas de oportunidades políticas empregado na sociologia é claro e operacionalizado por meio das cinco dimensões já citadas: a multiplicidade de centros de poder dentro de um regime; a abertura a novos atores políticos; a estabilidade ou instabilidade dos alinhamentos políticos em dado momento; a disponibilidade de aliados influentes; e o grau de repressão ou incentivo às demandas coletivas (Tarrow, 2005). Contudo, quando considerado na intersecção dos planos doméstico e internacional e somadas as percepções potencialmente distintas de várias organizações da sociedade civil que formam redes e coalizações transnacionais, a definição torna-se mais complexa. Além disso, dada a ausência de um centro de poder acima dos Estados as dimensões colocadas por Tarrow não são facilmente transpostas. Como mencionado, Sikkink operacionaliza este conceito por meio do nível de acesso a instituições, o que significa o quanto instituições são abertas ou fechadas às pressões e à participação de movimentos sociais (2005: 155). Como vários autores argumentam, as estruturas de oportunidades políticas não são dados objetivos da realidade, mas 
precisam ser percebidas e interpretadas pelos movimentos como tal. Isso nos leva a considerar, portanto, uma dimensão associada a fatores ideacionais e identitários na ação dos movimentos, que tem sido pouco tratada na área. Por estudar majoritariamente as redes que emergem em torno dos direitos humanos, esta não é uma dimensão muito explorada por Sikkink que, em grande medida, assume este valor compartilhado como fonte dos interesses das várias organizações.

As relações transnacionais entre organizações, coalizões e ativistas contra o livre comércio se inserem no que Sikkink denominou transnacionalismo defensivo, ou seja, atores se mobilizam no plano internacional para evitar possíveis perdas advindas de negociações consideradas por estes atores como desfavoráveis a seus interesses, portanto, se mobilizam contra normas que, se aprovadas, restringiriam suas estruturas de oportunidades, mas também pressionam pela adoção de novas práticas, como a abertura de consultas e participação de setores da sociedade nas negociações. Este tipo de tema aponta como não é tão simples separar atores entre aqueles guiados por propósitos econômicos ou princípios e valores, já que interesses e valores se constituem mutuamente.

Para avaliar o impacto do NAFTA no ativismo transnacional, Kay (2005; 2011) toma como unidade de análise a emergência das relações transnacionais entre sindicatos, definido como interações sustentadas, baseadas na equidade, em objetivos de longo prazo e interesse mútuo (2005:716). Para a autora, a explicação para a construção de relações duradouras e solidárias entre os sindicatos estudados (FAT, UE e CUSWA ${ }^{4}$ ) reside na emergência de novas estruturas de oportunidades

\footnotetext{
${ }^{4}$ Os casos estudados pela autora são a Frente Auténtica del Trabajo no México (FAT central independente mexicana, ao contrário da CTM, ligada ao PRI, que foi a favor do NAFTA desde o princípio); a United Electrical, Radio and Machine Workers of America (UE independente da AFL-CIO, com foco no sindicalismo democrático); e o Canadian Steelworkers of America (CUSWA - parte da United Steelworkers of America, mas com postura independente).
} 
políticas com a criação do NAFTA, particularmente com o acordo lateral sobre questões trabalhistas (NAALC). A consolidação de relações transnacionais dar-se-iam num processo de cinco etapas: contato; interação e convergência de interesses; crescimento da confiança; ação (atividades conjuntas); e identificação (reconhecimento de interesses mútuos) (2005:725).

Segundo Kay, o NAFTA catalisou o transnacionalismo sindical de duas formas: na primeira etapa entre 1989 e 1993, estimulou a mobilização política dos sindicatos para impedir a aprovação do acordo. Num segundo momento, a partir de 1994, teve um efeito institucional porque criou novas instituições através das quais sindicalistas puderam nutrir relações transnacionais. O NAALC estabeleceu novas regras, procedimentos e instâncias, como o NAO (National Administrative Office), para julgar violações trabalhistas. Mas as ações deveriam ser dirigidas ao NAO de outro país, não onde ocorreu a violação. Desse modo, estimulou os sindicatos a procurarem aliados em outros países do NAFTA (2005:718). $A$ autora enfatiza que ambos os momentos tiveram um efeito constitutivo: a criação de novos interesses na fase de mobilização política e a legitimação dos atores durante o período de institucionalização (2005:724).

Frente ao caso do NAFTA, a autora propõe novas dimensões para se pensar as estruturas de oportunidades políticas em âmbito transnacional. Diferentemente do nível doméstico, a autora sugere que no plano transnacional, as estruturas de oportunidades políticas pressupõem: a constituição de atores e interesses transnacionais; a definição e o reconhecimento de direitos transnacionais; e o julgamento de direitos no nível transnacional (Kay, 2005:721-723). A abordagem de Kay enfatiza a dimensão estrutural fornecida pelo NAFTA para a explicação de relações transnacionais. Contudo, considerando que a ideia de estruturas de 
oportunidades políticas tem sido interpretada não como um dado objetivo da realidade, mas como uma dimensão que deve ser percebida pelos atores para estimular a transnacionalização da ação coletiva, não fica muito claro como os próprios atores que se engajam na ação transnacional são eles próprios parte das estruturas de oportunidades políticas no âmbito transnacional ou como o reconhecimento e o julgamento de direitos, que poderiam ser considerados resultados da ação, são também considerados como dimensão desta mesma estrutura de oportunidade política.

No plano da agência, Kay aponta como diversos sindicatos responderam de forma diferenciada a esta nova arena internacional, sendo que os sindicatos de orientação ideológica mais progressista estabeleceram mais relações transnacionais que os sindicatos de orientação política mais conservadora. Além disso, destaca-se no trabalho da autora a ênfase em outro modo de interação com os Estados e a arena internacional, neste caso provida pelo NAFTA que, embora não estivesse isenta de conflitos, se manifestou não apenas pelos tradicionais repertórios de confronto, mas por canais institucionais que, mesmo que tímidos, mostraram-se um instrumento relevante para a atuação transnacional dos sindicatos:

Governance institutions that have concrete mechanisms to engage and enable nonstate actors to participate, the NAFTA story shows, are much more efficacious for transnational movement building (...) If the development of national social movements requires nation-states, the case of NAFTA implies that statelike entities in the international arena can play a pivotal role in the development of transnational social movements. Thus, the creation of new global governance institutions that provide mechanisms for social movement engagement and participation should help stimulate growth of transnational social movements. (Kay, 2011)

No caso da ALCA ao contrário, estudos mostram como, no limite, a ausência de canais institucionais de participação estimularam a construção de uma coalizão (Von Büllow, 2010) ou um movimento social transnacional (Berron, 2007). A mobilização continental contra o livre 
comércio tem sido um tema importante para a análise do ativismo transnacional: explicar o porquê e como organizações variadas, do norte e do sul, se envolveram numa coalizão multisetorial, com abrangência hemisférica traz novos desafios aos debates sobre o transnacionalismo.

Berrón (2007) identifica nestas mobilizações a formação de um movimento social transnacional, cuja expressão mais organizada seria a Aliança Social Continental. Ao contrário de redes e coalizões, a caracterização como movimento social toma como base a existência de uma identidade compartilhada, que por sua vez permite a definição de estratégias conjuntas. O elemento explicativo reside centralmente na formação da identidade:

É aqui então que faz-se necessário falar de "movimento social transnacional" como um espaço que compartilha um núcleo identitário comum, que justamente o identifica como tal, mesmo na diversidade de suas expressões organizativas, ao mesmo tempo que lhe outorga os elementos que permitem a sua constituição em agente, a elaboração de estratégias e a possibilidade política de partir para a ação. (Berrón, 2007: 113)

O autor classifica as identidades em três níveis sobrepostos: identidades primárias simples, organizadas nos níveis domésticos; identidades secundárias ou complexas domésticas, como as coalizões nacionais contra o livre comércio; e identidades complexas transnacionais, como o movimento continental e as suas expressões organizadas (2007:139). Mapeando a composição das coalizões locais contra o livre comércio Berrón descreve uma série de identidades primárias, como sindical, camponesa, feminista, ambientalista, indígena, estudantil, entre outras. Ao longo da análise de documentos de organizações representantes destas variadas identidades, em diversos países do continente, o autor demonstra como as negociações de acordos de livre comércio, em particular a ALCA, são percebidos e construídos como o inimigo, o outro em oposição a um nós baseado numa identidade ainda primária. Em seguida, parte para a análise de algumas coalizões domésticas, como a 
Rede Mexicana de Ação contra o Livre Comércio (RMALC) e a Rede Colombiana de Ação (RECALCA), mostrando como as identidades primárias se aglutinam em identidades secundárias domésticas, por meio da construção de um inimigo comum (2007:172-182). Por fim, a análise segue para a construção de identidades complexas transnacionais, aglutinando as diversas identidades primárias e secundárias domésticas numa nova construção discursiva de caráter continental, que passa a incorporar os diversos elementos das identidades primárias (2007:182193)

Von Büllow (2010) estuda o mesmo caso, mas sob perspectiva distinta. A autora propõe explicar as trajetórias para a transnacionalidade tomadas por organizações da sociedade civil por meio da inserção destes atores em redes sociais e contextos políticos específicos nos quais a ação se desenvolve (Von Büllow, 2007:6). A tipologia construída para descrever os diversos caminhos para a transnacionalidade fundamenta-se em duas dimensões: a escala da ação (doméstica ou internacional) e variação no tempo (pontual ou sustentada). Esta tipologia é aplicada a dois problemas enfrentados pelas organizações da sociedade civil frente à ação coletiva transnacional: problemas de coordenação e construção de coalizões (organizacionais) e a busca de políticas, ideias e interpretações/frames comuns (ideacionais). No caso das trajetórias organizacionais, por exemplo, teríamos 4 tipos: capítulos nacionais de campanhas transnacionais (como a Campanha Nacional contra a ALCA); campanhas transnacionais propriamente ditas (Campanha Continental contra a ALCA); capítulos nacionais de alianças e federações transnacionais (Rebrip no caso brasileiro); alianças e federações transnacionais (Aliança Social Continental).

Em termos transnacionais, as redes mapeadas mostram alta concentração de laços fortes entre um pequeno número de organizações: centrais sindicais, organizações rurais e um pequeno número de ONGs 
ocupam as posições centrais da rede (2010:79). No caso das centrais sindicais, por exemplo, esta centralidade seria em parte explicada pelo contexto político (fim da Guerra Fria e a progressiva dissolução da desconfiança entre centrais sindicais causada pela rivalidade Leste-Oeste) e relacional das organizações (experiências prévias de redes no Mercosul e Nafta) (2010:86). Mas nem todas as organizações sindicais ocupam posições tão destacadas na rede. A centralidade de organizações como CUT, FAT e AFL-CIO seria o resultado da decisão de procurar laços com outras organizações, que pressupõe uma ampliação de seus temas para além da agenda sindical específica.

Com a tipologia organizacional e ideacional percebemos que a interpretação das estruturas de oportunidades políticas e a resposta a elas por parte das organizações da sociedade civil variam. A escolha entre estes caminhos é informada pela história de cada organização, mas também é o resultado da inserção política e relacional dos atores:

The main argument is that actors have built organizational arrangements that are influenced by previous social networks and coalitions, but that these have been rearranged through the creation of new ties and efforts to balance power relations, the diffusion of successful experiences and their adaptation in new environments, and the creation of brokerage roles that link the national and transnational scales. (Von Büllow, 2010: 117)

O mapeamento das posições ocupadas pelas organizações da sociedade civil nas redes nacionais e hemisférica dá base muito consistente às diferentes trajetórias para a transnacionalidade. As motivações para estas escolhas são fundamentadas no contexto histórico e relacional de cada organização.

Os casos do NAFTA e da ALCA considerados acima iluminam aspectos diferentes sobre a construção de relações transnacionais entre atores da sociedade civil. No caso do projeto hemisférico, foi justamente a oposição ao projeto por parte de organizações variadas que motivou a formação de coalizões e de um movimento social transnacional. A oposição e a 
resistência à ALCA deram fundamento a um repertório de confronto político que incluiu marchas, cúpulas paralelas, plebiscitos populares, entre outros. No NAFTA, apesar de protestos iniciais, depois da entrada em vigor do Acordo, alguns sindicatos adotaram a estratégia de usar um canal institucional criado para tratar de temas trabalhistas, o que também estimulou a constituição de interesses e estratégias compartilhadas.

Outros estudos de casos mostram também um cenário mais matizado, no qual várias estratégias de ação mesclam-se numa combinação de resistência e participação. Este é por exemplo o caso da Campanha Global pela Reforma Agrária, da Vía Campesina, que simultaneamente adotou uma estratégia de confronto político com Ols como o Banco Mundial e o FMI, e colaboração com a FAO na elaboração de projetos, documentos e seminários (Borras, 2008). A combinação de estratégias de resistência e participação também ocorreu durante as Conferências Mundiais da ONU, quando uma série de ONGs e movimentos sociais inauguraram a realização de cúpulas paralelas às oficiais, ao mesmo tempo em que algumas destas organizações eram credenciadas para participar de atividades com os governos (Friedman et al, 2001). Smith e Korzeniewicz diferenciam entre estratégias insider e outsider:

Adoptando una estrategia "insider", algunas redes y coaliciones de la sociedad civil privilegiaron el desarrollo de una política de cooperación y colaboración con los gobiernos, la Organización de los Estados Americanos (OEA), instituciones financieras internacionales como el Banco Mundial y el Banco Interamericano de Desarrollo y otros organismos multilaterales, y buscaron articular repertorios de acción colectiva centra dos en las agendas oficiales y la reforma gradual. Otras redes y coaliciones transnacionales adoptaron una estrategia "outsider", privilegiando los vínculos con movimientos sociales de base $y$ organizaciones sindicales, desarrollando identidades opositoras $y$ estrategias de confrontación frente a la globalización y los planes de integración económica regional, buscando así repertorios de acción colectiva centrados en la movilización y en la contestación al orden social vigente (Smith e Korzeniewicz, 2006:43) 
A perspectiva neogramsciana sobre a atuação de organizações da sociedade civil em arenas transnacionais dão pistas sobre estas duas dimensões da ação transnacional - formas de resistência/repertórios de protesto e participação em canais institucionalizados de organizações internacionais. Também a literatura sobre o novo transnacionalismo fornece mecanismos para a compreensão de interações entre organizações da sociedade civil e as instituições internacionais de governança e de integração regional. No entanto, a influência da abordagem do processo político da teoria dos movimentos sociais tende a privilegiar a ação coletiva de dimensão extrainstitucional, em geral causada pela ausência ou pouca permeabilidade dos canais de diálogo doméstico ou internacional, tornando invisíveis outras formas de interação. A princípio, a própria particularidade das relações internacionais geraria este viés, na medida em que instâncias de consulta a organizações da sociedade civil são tratadas via de regra nos debates sobre democratização do Estado, democratização que não poderia acontecer num sistema formado por unidades soberanas e sem um poder supranacional. Contudo, apesar de graus variados de eficiência, a existência de mecanismos participativos ligados à instituições internacionais sugere a necessidade de analisar como as organizações da sociedade civil fazem uso estratégico destes espaços institucionalizados de participação em complementação e/ou substituição a um repertório mais contencioso.

A intenção deste trabalho é contribuir com este debate a partir da atuação transnacional de organizações da sociedade civil brasileiras no Mercosul, com atenção especial à como a interação entre os planos doméstico e regional é percebida por estas organizações e motivam a combinação de estratégias de ação contenciosa e participativa.

Antes de prosseguir, cabe contudo esclarecer um ponto frequentemente implícito na literatura. No âmbito da sociologia, as teorias de movimentos 
sociais travaram um longo debate sobre a definição de seu objeto de estudo (Della Porta e Diani, 2006; Alonso, 2009), de modo que os trabalhos neste campo são rigorosos ao qualificar grupos como "movimentos sociais". A intersecção com as Relações Internacionais no plano teórico e uma série de protestos internacionais ligados ao altermundialismo no plano empírico, que reuniram uma gama muito heterogênea de atores em redes e coalizões transnacionais - movimentos sociais propriamente ditos, ONGs locais e internacionais, sindicatos, movimentos religiosos, organizações de defesa do consumidor, entre outros -, diluíram um pouco estas fronteiras ao adaptar contribuições da teoria dos movimentos sociais para a dimensão transnacional. Neste sentido, a transposição de conceitos da abordagem do processo político para a agenda de pesquisa do transnacionalismo significa em grande medida lidar com outros atores além dos movimentos sociais stricto sensu. Ao explicar a emergência de uma coalização transnacional contra o livre comércio nas Américas, Von Bullow (2010), por exemplo, usa o termo "organizações da sociedade civil" para designar de forma não específica os vários atores identificados na rede (sindicatos, ONGs e movimentos sociais). Este trabalho seguirá esta mesma denominação. Tomamos a sociedade civil como um espaço político diverso, que engloba uma série de associações e entidades, tais como ONGs, instituições acadêmicas, sindicatos, entidades religiosas, movimentos sociais diversos, entre vários outros (Scholte, 2002; Von Büllow, 2010) ${ }^{6}$. Ao utilizar o termo "organizações da sociedade civil" não se tem em mente

\footnotetext{
${ }^{5}$ Após o embate e as sínteses entre as teorias do processo político e dos novos movimentos sociais, aceitamos aqui a definição de Diani (apud Della Porta e Diani, 2006) de movimentos sociais como um processo social distinto, que consiste em mecanismos pelos quais os atores engajados na ação coletiva estão envolvidos em relações conflituosas (culturais e/ou políticas) com oponentes claros, estão ligados por densas redes informais; e compartilham uma identidade coletiva.

${ }^{6}$ Segundo Scholte, a sociedade civil se refere a um political space where voluntary associations deliberately seek to shape the rules that govern one or the other aspect of social life (...) Civil society can encompass many sorts of actors: academic institutes, business forums, clan and kinship circles, consumer advocates, development cooperation initiatives, environmental movements, ethnic lobbies, foundations, human rights promoters, labour unions, local community groups, relief organisations, peace activists, professional bodies, religious institutions, women's networks, youth campaigns and more. (Scholte, 2002: 284)
} 
nenhuma pretensão de homogeneidade entre estes atores, apenas uma referência não específica a grupos diversos. O "conteúdo" da sociedade civil no Mercosul será especificado a partir da pesquisa empírica. Por ora, é possível afirmar que em grande parte dos anos noventa são os movimentos sindicais que atuam de forma mais organizada; no período recente, estas "organizações da sociedade civil" incluem também ONGs, movimentos agrários, movimentos de mulheres, cooperativas e outros que serão identificados ao longo da pesquisa. Desta forma, não se usa a expressão como um conceito, mas como referência mais geral a uma série de organizações diversas que se engajam na ação regional ao longo do tempo.

\section{Organizações da sociedade civil e o Estado}

Há uma longo acúmulo na literatura brasileira em torno dos debates sobre movimentos sociais, sociedade civil e instituições participativas. Nos anos 70 e 80, a discussão envolveu o ressurgimento de uma série de movimentos sociais e populares em oposição ao regime autoritário; os anos noventa, por um lado, trouxe um período de debates mais normativos sobre o conceito de sociedade civil, com forte influência habermasiana e, por outro, uma produção com foco mais empírico, que descrevia as experiências participativas a partir da redemocratização (como os conselhos gestores e o orçamento participativo) (Lavalle, 2003).

No plano teórico, as discussões sobre participação e sociedade civil se fizeram presentes, por exemplo, na crítica às teorias da transição democrática e sua ênfase na esfera institucional que negligenciaria a democracia no âmbito das relações sociais e da cultura política (Avritzer e Costa, 2004) e na contribuição das experiências participativas para o conceito argumentativo de deliberação democrática (Avritzer, 2000). Uma série de trabalhos também lançaram luz sobre as variadas experiências 
participativas e sobre uma tradição de esquerda surgida durante a redemocratização, muito associada às experiências no âmbito de prefeituras administradas pelo Partido dos Trabalhadores (Abers, 1996; 1998; Santos, 2002; Avritzer, 2005).

Na última década, a literatura tem evoluído do debate normativo e do estudo de experiências locais para entender os efeitos mais gerais da proliferação de canais participativos com os mais variados formatos institucionais em todas as esferas de governo do Estado brasileiro (Lavalle, 2011a). Nesta linha, um dos desdobramentos recentes tem se sido a tentativa de recolocar a relação entre Estado e movimentos sociais/organizações da sociedade civil menos na chave essencialista da separação entre estas esferas e na dicotomia conflito/cooptação, e mais na compreensão da interação entre ambas, em como os conflitos se desenvolvem nos mecanismos participativos e em como os movimentos combinam estratégias extrainstitucionais de mobilização e pressão com a participação institucionalizada.

Segundo Dagnino (2002:10), após luta unificada contra o autoritarismo, a redemocratização expôs a heterogeneidade da sociedade civil e o caráter autoritário de mecanismos que ordenam a sociedade brasileira em seu conjunto, o que estimulou preocupações com a construção de uma nova ideia de cidadania e espaços públicos. Teríamos aqui o desenvolvimento de novas relações entre Estado e sociedade civil:

(...) o antagonismo, o confronto e a oposição declarados que caracterizavam essas relações no período da resistência contra a ditadura perdem um espaço relativo substancial para uma postura de negociação que aposta na possibilidade de uma atuação conjunta, expressa paradigmaticamente na bandeira da "participação da sociedade civil" (2002:13).

Apesar destas novas formas de relação e dos mecanismos participativos, o conflito em torno da partilha efetiva do poder seria um elemento central destes espaços. Contudo, este conflito não seria explicado apenas por 
uma oposição natural entre Estado e sociedade civil, mas seria atravessado pela construção histórica dessas relações, no sentido de que elas são objeto da política e, portanto, transformáveis pela ação política (2002:280). Esta clivagem em termos políticos, históricos e culturais é apresentada com a ideia de projeto político, entendido como um conjunto de crenças, interesses, concepções de mundo, representações do que deve ser a vida em sociedade, que orientam a ação política dos diferentes sujeitos. (2002:282). A partir de uma série de estudos empíricos sobre experiências participativas, a autora identifica que uma parcela destes casos (como os OPs em Porto Alegre e Belo Horizonte) seriam explicados pelo compartilhamento de um projeto político participativo e democratizante, que apresentariam um elemento recorrente: a existência de indivíduos em posições-chave no interior do aparato estatal que se comprometem individualmente com os projetos participativos.

Em artigo recente, Abers e Von Büllow, questionam como o estudo dos movimentos sociais, ao delimitar um tipo específico de ação coletiva, tem tornado invisível outras formas de organização e ação social. De forma mais específica, questionam a exclusão a priori de atores posicionados na arena estatal e a insuficiência do instrumental analítico disponível - tanto nas abordagens centradas no processo político, quanto na sociedade civil - para entender a interação entre movimentos sociais e Estado. Segundo as autoras, apesar de distintas, as duas abordagens presumem que os movimentos podem ser definidos como inerentemente distintos do Estado, ou em outras palavras, os ativistas interagem com o Estado, mas não participam diretamente da gestão estatal (2011:64). Contudo, segundo Abers e Von Büllow, na América Latina - e no Brasil, em particular - as redes de movimentos sociais cruzam esta fronteira com frequência. Ao lutar pela transformação de comportamentos sociais e para influenciar políticas públicas, muitas vezes os movimentos demandam a criação de espaços participativos mas, para além destas instâncias, a literatura não considera a presença de ativistas de movimentos sociais dentro do próprio 
Estado como uma forma de interação. Este tipo de interação colocaria em xeque tanto a ideia de autolimitação das abordagens mais normativas centradas na sociedade civil, como também a presunção de que a relação entre Estado e movimentos sociais transformadores é sempre conflituosa. (2011:71)

Abbers, Tatagiba e Serafim (2014) adotam uma linha semelhante ao analisarem a implementação de mecanismos participativos na administração federal a partir dos governos de Luiz Inácio Lula da Silva. Segundo as autoras, a realização de dezenas de conferências e a criação de novos conselhos gestores se devem menos a um compromisso geral do governo com a participação e mais às dinâmicas políticas dentro de cada setor de política pública. Pela primeira vez antigos líderes sindicais e líderes políticos com fortes vínculos com movimentos sociais assumem altos cargos no governo. As autoras desenvolvem o argumento de que, neste contexto de maior proximidade, movimentos sociais e agentes estatais reinterpretariam os padrões tradicionais de interação entre Estado e sociedade: ativistas que assumiram cargos na burocracia federal frequentemente transformaram agências governamentais em espaços de militância nos quais continuaram a defender bandeiras desenvolvidas previamente no âmbito da sociedade civil (Abers et al., 2014:326). Para incluírem este tipo de relação, adaptam o conceito de repertório de confronto de Tilly com a ideia de repertórios de interação:

\footnotetext{
A literatura internacional sobre ação coletiva tem historicamente focado nas relações entre Estado e movimentos sociais sob a perspectiva do conflito e, por esta razão, a categoria de protesto é um componente central do repertório de movimentos sociais como Tilly e Tarrow descrevem (...) Os movimentos sociais brasileiros não apenas negociam frequentemente com o Estado (o que nos permitiria trabalhar como conceito original de repertório de Tilly) mas também investiram pesadamente em ações por dentro das instituições do Estado, tanto através de novas arenas participativas como assumindo estrategicamente posições na burocracia, transformando o próprio Estado em espaço de militância política. (Abers et al., 2014:331)
} 
$\mathrm{Na}$ mesma linha, Carlos (2011) critica o enfoque organizacional que compreende a inserção institucional de movimentos sociais como um processo de burocratização e profissionalização. Para a autora, estas perspectivas desconsideram os incentivos gerados à participação pelo desenho inovativo das instituições participativas. (Carlos, 2011:316). A combinação de estratégias intra e extrainstitucionais no contexto de relações históricas com o partido no governo também se fazem presentes:

\begin{abstract}
Movimentos sociais possuem a habilidade de combinar uma pluralidade de formas de ação que perpassam estratégias contenciosas ou disruptivas, ações formais de encaminha- mento de demandas, e alianças com partidos políticos, políticos e ex-lideranças do movimento. A combinação entre essas formas de ação é contingente e dinamizada pela relação sociedade-Estado de cada contexto histórico (...) As motivações para interações cooperativas na relação sociedade-Estado podem ser encontradas em dois fatores interdependentes: na relação histórica dos movimentos com os partidos políticos no poder e na absorção da proposta de participação pelo governo. (Carlos, 2011: 331 e 339)
\end{abstract}

\title{
Objeto de pesquisa - os encontros entre organizações da sociedade civil e a integração regional no Mercosul
}

Entre o final dos anos oitenta e início dos noventa testemunhamos uma onda de formação de blocos regionais, marcados majoritariamente pela liberalização comercial. Na América Latina este processo coincidiu com o período de reforma do Estado, reforçando o caráter de abertura econômica que orientava os processos de integração na região.

O Tratado de Assunção assinado em 1991 estabeleceu prazos para a constituição de uma mercado comum entre Argentina, Brasil, Paraguai e Uruguai que, em 1994, adquiriu o desenho institucional de uma união aduaneira com o Protocolo de Ouro Preto. Dada sua orientação comercial inicial e a ideia de uma estrutura institucional intergovernamental enxuta, o Tratado de Assunção não previu a participação de empresas, sindicatos ou outros atores da sociedade em canais oficiais de consulta e diálogo. 
Contudo, desde o início, atores não-estatais reivindicaram participar das negociações. Nos primeiros anos as centrais sindicais foram os movimentos mais presentes, mas, ao longo do tempo outras organizações se incorporaram no processo.

Ao longo de quase vinte e cinco anos do Mercosul, as estratégias de atuação das centrais sindicais, de forma particular e, das organizações da sociedade civil de forma mais geral, têm combinado ações de um repertório mais tradicional de confronto político (como sugere o trecho da reportagem que abre este capítulo) com a participação em canais institucionais, tanto no âmbito do Mercosul propriamente dito, quanto no plano nacional em espaços mais recentes de consulta sobre a formulação de políticas para o bloco.

A partir de mudanças nos repertórios de confronto e participação, trabalharemos com três períodos. A primeira fase compreende o período de transição (da assinatura do Tratado de Assunção ao Protocolo de Ouro Preto, em 1994) e segue até 1998 com o lançamento oficial das negociações da Área de Livre Comércio das Américas (ALCA), que alterou significativamente o panorama da atuação das organizações da sociedade civil no plano regional. A segunda fase engloba o período de 1999 a 2005, marcado por sucessivas crises no Mercosul (desvalorização unilateral da moeda brasileira em 1999, moratória argentina em 2001), pela intensificação das negociações da ALCA e pelas mobilizações contra o livre comércio, que ganharam escala continental. A terceira e última fase, a partir de 2006, é marcada pelo fim das negociações hemisféricas, pela tentativa de relançamento do Mercosul a partir de uma reorientação política, pela persistência de crises e pela criação de novos mecanismos de participação.

A primeira fase se caracterizou pelo processo de reforma do Estado e abertura econômica em todos os países do bloco. As centrais sindicais 
foram os atores que participaram de forma mais sustentada e organizada, externalizando reivindicações domésticas, no contexto de implementação de políticas neoliberais. O movimento sindical reivindicava a criação de mecanismos institucionais de consulta às sociedades, bem como a adoção de políticas e instrumentos supranacionais que pudessem potencialmente compensar as perdas no plano doméstico. $A$ atuação se deu majoritariamente por meio da participação no subgrupo encarregado de relações trabalhistas e no Fórum Consultivo Econômico e Social. Fora do âmbito institucional, destacou-se a construção de uma coalizão transnacional no interior da Coordenadora de Centrais Sindicais do Cone Sul, que ensaiou um processo de difusão, com a criação de comissões sindicais setoriais. No final desta fase, já com a perspectiva mais concreta de avanços nas negociações da ALCA, o uso de repertórios contenciosos mais tradicionais, com a realização de alguns protestos e marchas, bem como cúpulas sindicais paralelas, se somaram à participação institucionalizada.

Na segunda fase, a partir de 1999, o Mercosul perdeu ímpeto com uma sucessão de crises e, simultaneamente, com o avanço das negociações comerciais hemisféricas. Para este trabalho, a novidade da ALCA foi a inclusão de um terceiro plano de oportunidades políticas (neste caso ameaças políticas) que se agregou à interação entre os planos doméstico e subregional. Justamente no plano hemisférico, registrou-se a formação de uma ampla e inédita coalizão transnacional composta por movimentos sindicais, ONGs e movimentos sociais, cuja estratégia central era a oposição e o enfrentamento político do projeto de livre comércio, com a realização de marchas, protestos e cúpulas paralelas às oficias (as chamadas cúpulas dos povos se consolidaram como um repertório de ação frequentemente utilizado pelos movimentos).

A terceira e última fase se caracterizou por várias mudanças em comparação ao contexto anterior. No Brasil, na Argentina e no Uruguai, 
partidos (ou um setor do partido, no caso argentino) de esquerda e centroesquerda - que direta ou indiretamente estiveram associados com os movimentos sociais nas mobilizações contra a ALCA - chegaram pela primeira vez aos governos nacionais. Embora haja inúmeras diferenças nas políticas domésticas, há uma convergência inicial significativa em torno da mudança de rumos nos processos de integração regional. No caso do Mercosul, os conflitos comerciais permaneceram, mas foram minimizados pela diversificação da agenda com a inclusão de temas sociais e de direitos humanos e pela criação de novos mecanismos participativos. No plano hemisférico, além da forte mobilização social, a oposição de setores domésticos nos EUA, e a mudança na orientação diplomática no Brasil e na Argentina, associadas à Venezuela, levaram ao adiamento sine die das negociações da ALCA em 2005. Além disso, também neste período, tivemos o lançamento de uma iniciativa de integração regional política da América do Sul, com a criação da Comunidade Sul-Americana de Nações (CASA). O cenário se tornou mais diverso e colocou novos desafios às organizações da sociedade civil frente à abertura de novos canais de diálogo e à participação institucionalizada no Mercosul. No caso brasileiro, a presença de militantes de sindicatos, movimentos sociais e partidos de esquerda no poder Executivo e as tentativas de aprofundamento das dimensões política e social da integração, em sintonia com as antigas reivindicações do movimento sindical, levaram a à criação do Conselho/Programa Mercosul Social e Participativo no âmbito do governo federal e à transformação de um dos principais repertórios de confronto político da fase de mobilização contra a ALCA - as cúpulas paralelas - em atividades institucionalizadas e organizadas pela Presidência Pro Tempore - as cúpulas sociais do Mercosul.

Após o fim das negociações da ALCA, a desmobilização de estratégias extrainstitucionais não foi imediata. As ONGs e os movimentos sociais e sindicais que haviam se articulado na luta continental contra a ALCA 
buscaram manter a mobilização, sobretudo por meio da organização autônoma de Cúpulas paralelas, desta vez a partir de um viés "propositivo", de modo a pressionar os novos governos por mudanças na integração regional. Por outro lado, uma parcela destas organizações também passou a participar dos novos canais de consulta criados pelos governos no âmbito do Mercosul, de maneira que as Cúpulas Sociais e o PMSP passaram a contar com uma diversidade de organizações que antes não atuavam na esfera regional. Este processo mostrou vitalidade até 2010, mas nos últimos anos vem experimentando certo declínio. As cúpulas autônomas foram organizadas até 2010 e, embora as cúpulas sociais e as reuniões do PMSP se mantenham, há uma percepção generalizada de "esvaziamento" destas iniciativas. É difícil mensurar esta percepção de "diminuição de ritmo", porque como estes canais financiam a assistência das organizações da sociedade civil, raramente elas deixam de participar. A afirmação de certo grau de esvaziamento nos últimos anos é feita a partir da percepção dos entrevistados, da sucessiva troca do interlocutor responsável por estes canais no governo brasileiro e pela observação participante em algumas reuniões do PMSP (em 2013 e 2014) e de uma Cúpula Social (em 2012). Embora esta observação participante não possa ser comparada com o período prévio (já que foi realizada entre 2012 e 2014), mostrou discussões superficiais e repetitivas que aparecem na fala dos entrevistados.

\section{Hipóteses de trabalho e considerações metodológicas}

Segundo Sikkink (2005), quando os planos doméstico e internacional são percebidos como favoráveis às demandas das organizações da sociedade civil, o ativismo tenderia a concentra-se no nível doméstico. Por outro lado, Kay (2011) argumenta que a criação de canais participativos em estruturas internacionais de governança poderia fomentar a construção de relações transnacionais entre as organizações da sociedade civil. 
A partir do diálogo com a literatura e do caso do Mercosul, as hipóteses de trabalho desta pesquisa são que:

1) embora a abertura simultânea das estruturas de oportunidades políticas doméstica e regional preconize a diminuição do ativismo transnacional, a existência de mecanismos participativos poderia manter a atuação das organizações da sociedade civil, inclusive com um caráter mais sustentado ao longo do tempo (e não apenas em torno de campanhas transnacionais), gerando assim uma nova prática, adicional aos tradicionais repertórios de confronto.

2) o declínio da atuação das organizações da sociedade civil em torno da integração regional no Mercosul não seria portanto reflexo da abertura das estruturas de oportunidades políticas doméstica e regional, mas sim reflexo das próprias dificuldades do Mercosul como uma instituição regional de governança.

Como vários autores já argumentaram (Keck e Sikkink, 1998; Tarrow, 2005; Sikkink, 2005; Berrón, 2007; Von Büllow, 2010), estruturas de oportunidades políticas não são dados estáticos da realidade, mas precisam ser percebidas, alteradas e/ou criadas pelos atores. Nesse sentido, este trabalho pretende investigar como a mudança de governos na região e, particularmente a abertura de novos canais de diálogo relativos ao Mercosul, são percebidas pelas organizações que se articulavam no período prévio e como esta percepção se reflete no uso de repertórios de confronto e/ou participação neste novo cenário.

Tarrow trabalha com a identificação de processos e seus mecanismos, que ao conectar o local e o internacional constituem uma dimensão transnacional de conflito político (2005:29). Segundo o autor, mecanismos não são variáveis, mas são uma classe delimitada de eventos que alteram as relações entre elementos específicos de forma idêntica ou muito semelhante numa variedade de situações (ibidem). Nesta abordagem, mecanismos são causais e pressupõe uma relação de causalidade. 
Segundo Beach e Pedersen (2012:39,40) discutir mecanismos pressupõe um debate prévio sobre a natureza da causalidade nas ciências sociais, dividida entre duas abordagens: uma lógica frequentista, que entende que não podemos enxergar a causalidade em operação e que, portanto, explicar causalidade é identificar regularidades entre causa e efeito (o que exige um grande número de casos); e uma lógica baseada em mecanismos, que parte da premissa de que é possível identificar o processo causal que liga um efeito a um resultado. É justamente nesta segunda lógica que ganha corpo as abordagens em torno de mecanismos causais em estudos de caso.

Na obra de 1998, na qual identificam o padrão bumerangue como um mecanismo recorrente numa variedade de casos de formação de redes transnacionais, Keck e Sikkink levam uma perspectiva constitutiva aos mecanismos, ao considerarem como as redes transnacionais de advocacy mobilizam normas internacionais e assim podem potencialmente alterar $\mathrm{o}$ comportamento de Estados, não apenas de forma instrumental, mas no limite modificando identidades e constituindo novas práticas. De forma que normas não causam práticas; esta relação é constitutiva: practices do not simply echo norms - they make them real (1998:35). As autoras buscam conciliar a ação estratégica com as interpretações constitutivas ao afirmarem que podemos pensar na atividade estratégica de atores num universo político estruturado intersubjetivamente (1998:5). Em geral, os autores que buscam conciliar estas duas perspectivas o fazem a partir da ideia de que inicialmente a mudança de comportamento se dá de forma instrumental, por cálculo de interesses, mas com o tempo pode ser internalizada e levar à mudança de identidades. (Sikkink e Risse, 1999; Checkel, 2005).

Este trabalho busca compreender como a participação em canais institucionalizados relativos à integração regional podem ser entendidos como uma tática complementar aos tradicionais repertórios de confronto 
estudados pelo transnacionalismo e como este processo pode constituir novos temas na agenda das organizações da sociedade civil. Embora o recorte temporal seja primordialmente o período iniciado com a chegada do Partido dos Trabalhadores ao governo brasileiro - com a reorientação nos processos de integração regional e o adiamento das negociações comerciais hemisféricas -, para entender o uso simultâneo de mobilizações extrainstitucionais e participação em canais oficiais de diálogo, bem como a própria consolidação das demandas por participação como um tema, far-se-á uma retomada da atuação de organizações da sociedade civil em torno da integração desde o início do Mercosul.

Com exceção dos anos noventa, quando a atuação no Mercosul centravase quase que exclusivamente nas representações sindicais e empresariais, o engajamento de organizações da sociedade civil passa a ser mais difuso no período seguinte. Isto porque as coalizões contra as negociações comerciais hemisféricas se formaram com a inclusão de vários movimentos sociais e ONGs ligados a múltiplos temas e com bases mais flexíveis e horizontais, se comparadas a federações sindicais internacionais mais hierárquicas e verticais. Também nos novos canais de diálogo no Mercosul, seja nas Cúpulas Sociais, seja no Programa Mercosul Social e Participativo (PMSP), há certa flutuação das organizações participantes e não há critérios definidos para determinar quem pode participar, não há portanto uma lista consolidada de integrantes. Assim, a seleção das organizações a serem entrevistadas (conforme lista no anexo 3) foi feita com base em trabalhos prévios (que identificaram a centralidade de atores nestas redes flexíveis contra negociações comerciais ${ }^{7}$ ), com base na observação participantes e nas informações providas pelos próprios entrevistados.

\footnotetext{
7 Berrón, 2007; Von Büllow, 2010
} 


\section{Capítulo II}

\section{Acordos de integração regional- do Tratado de Assunção ao fim das negociações da ALCA}

A década de oitenta registrou profundas mudanças na América Latina, combinadas a um cenário de novos constrangimentos internacionais. No plano político, vários países da região passavam por processos de redemocratização após ditaduras civis-militares e, particularmente no Brasil, o período experimentou ampla mobilização popular em torno da campanha das Diretas Já e a instauração da Assembleia Nacional Constituinte.

Depois de relativa abertura internacional às clivagens Norte/Sul, ao tema do desenvolvimento e às demandas dos países do terceiro mundo nas décadas anteriores, a América Latina vivia novas dificuldades com os efeitos da crise do petróleo, restrições de financiamento internacional com crise da dívida ${ }^{8}$ e com as mudanças na política monetária dos EUA durante o governo Reagan ${ }^{9}$. Ainda no plano internacional tinha-se o início da reorganização da economia internacional em torno de princípios neoliberais e novas pressões na América Latina por maior abertura econômica e liberalização comercial.

\footnotetext{
${ }^{8}$ No caso do Brasil, destaca-se a negociação da dívida externa bilateralmente com os credores, estratégia que prevaleceu entre economistas do ministério da Fazenda, do Planejamento e do Banco Central, e o enfraquecimento de uma estratégia mais política, dominante no Itamaraty, que defendia uma posição mais coordenada com o restante da América Latina (Cervo e Bueno, 2008).

${ }^{9}$ A maior parte dos contratos da dívida externa brasileira eram regidos por taxas de juros flutuantes (em 1988, $77,5 \%$ da dívida correspondia a taxas flutuantes), o que permitia a elevação unilateral dos serviços da dívida em função de ajustes na política monetária dos países centrais. Como ilustram Cervo e Bueno: O choque dos juros no início da administração Reagan evidenciou o desvirtuamento de tais contratos, firmados em sua maioria a taxas médias de $8 \%$ ao ano e tendo de ser liquidados a taxas que atingiram a média anual de 21,5\% em 1980 (2008: 437)
} 
No âmbito do GATT, a posição mais ofensiva dos países desenvolvidos com relação à liberalização comercial na Rodada Uruguai e a inserção dos chamados novos temas refletia uma mudança de atitude em reação às concessões de tratamento diferenciado aos países em desenvolvimento negociados na década anterior. Neste contexto os países industrializados cunharam o conceito de newly industrialized countries (NICs) e restringiram o Sistema Geral de Preferências negociado no GATT, o que, para o Brasil, resultou na perda de preferências comerciais na Comunidade Econômica Europeia e nos EUA, em 1981 (Cervo, Bueno, 2008: 443). Por sua vez, a inserção dos novos temas (regras relativas ao comércio de serviços, investimentos, propriedade intelectual) buscavam adaptar normas nacionais e internacionais que afetavam estes setores, de modo a construir um cenário mais favorável ao avanço competitivo dos países centrais (Mello, 1996: 241, 242).

Em paralelo às negociações multilaterais no GATT, registrava-se uma tendência à formação de blocos regionais, dentro do chamado "novo regionalismo" ou "regionalismo aberto" ${ }^{10}$ que, ao contrário da onda integracionista anterior, desta vez exibia um perfil mais liberal, segundo o qual os blocos regionais seriam etapas para atender a necessidade de uma inserção comercial mais ampla e competitiva colocada pelos processos de globalização. Neste sentido, a liberalização não ocorreria apenas entre os membros de um determinado bloco, mas também entre blocos regionais:

\footnotetext{
${ }^{10}$ Vale notar que a definição de "regionalismo aberto" é cunhada, entre outros, pela própria CEPAL, que nas décadas anteriores tinha sido inspiração para a proposta da ALALC e seu mercado ampliado para a substituição de importações. A partir da revisão de suas posições nas décadas anteriores, a CEPAL passa a definir o "regionalismo aberto" como um processo de crescente interdependência no nível regional, promovida por acordos preferenciais de integração e por outras políticas, num contexto de liberalização e desregulação capaz de fortalecer a competitividade dos países da região e, na medida do possível, constituir a formação de blocos para uma economia internacional mais aberta e transparente. (CEPAL, 1994:12,13)
} 
O termo regionalismo aberto se refere ao fato de que os processos regionais de integração econômica passaram a ser vistos como etapas intermediárias para a liberalização multilateral e não como fins em si mesmos. Nesse sentido, os blocos regionais passam a promover a liberalização entre eles, ou seja, não apenas uma liberalização intraregional, mas também inter-regional. (Herz, Hoffmann, 2004:166)

Esta nova orientação dos processos de integração regional possibilitou certa convergência entre as políticas comerciais dos EUA e da América Latina:

\begin{abstract}
Between the mid 1980s and the end of the 1990s, trade policies in the United States and Latin America increasingly converged, and a new wave of agreements was negotiated within an ideological framework given by neoliberal economic policies. Under the US leadership, the "new regionalism" consisted mainly of the negotiation of free trade areas, but with extended agendas that went much beyond trade liberalization. (...) they included specific elements of domestic policy harmonization that are typical of the formation of a custom union or of a common market (...) these agreements have included clauses on investor-state dispute settlement, intellectual property rights, labor rights, and environmental protection. They have remained silent, however, with respect to issues such as freedom of movement of labor and a common external tariff (Von Büllow, 2010: 50, 51)
\end{abstract}

Significativamente, os blocos regionais passaram a integrar a política comercial estadunidense que, até então, se opunha a tais acordos em prol da liberalização multilateral no GATT. Como exemplo, temos o Acordo de Livre Comércio EUA-Canadá, em 1988 (CUSFTA), a incorporação do México com o Acordo de Livre Comércio da América do Norte, negociado em 1989 (NAFTA) e o lançamento da Iniciativa para as Américas, pelo governo Bush em 1990.

Embora esteja inteiramente inserido neste contexto, o projeto de integração no Cone Sul será em parte uma exceção, na medida em que terá originalmente a ambição de formar um mercado comum, o que inclui o estabelecimento de uma tarifa externa frente a terceiros mercados e a livre circulação de pessoas. Segundo Mello (2002), esta opção refletiu desde o início a estratégia da política externa brasileira de fortalecer sua 
posição de barganha perante as negociações hemisféricas, a partir da articulação subregional no Mercosul ${ }^{11}$.

A aproximação entre Brasil e Argentina, que nos anos seguintes levaria à criação do Mercosul, teve origem com o fortalecimento das relações políticas entre os Presidentes José Sarney e Raul Alfonsín, materializada na Declaração de Iguaçu, assinada em novembro de 1985, que enfatizava a consolidação do processo democrático, a união de esforços na defesa conjunta dos interesses de ambos nos foros internacionais e o aproveitamento dos recursos comuns entre eles (Mariano, 2011: 27). Do ponto de vista econômico, a iniciativa ainda não podia ser caracterizada propriamente dentro dos marcos do regionalismo aberto, pois visava a abertura seletiva de mercados, a complementariedade produtiva e o desenvolvimento tecnológico, com o aumento da escala industrial dos dois países (Correa, 1996). A Ata para a Integração Brasil-Argentina, assinada em 1986, estabeleceu mais de duas dezenas de protocolos setoriais por meio do Programa de Integração e Cooperação Econômica (PICE). Em 1988, os dois países assinaram o Tratado de Integração, Cooperação e Desenvolvimento, de "caráter gradual, flexível e equilibrado", com o objetivo de constituir um espaço econômico comum em dez anos e estabelecer a coordenação de políticas macroeconômicas, comercial, aduaneira, industrial e agrícola. Numa segunda etapa adotar-se-iam as demais políticas necessárias para a formação de um mercado comum propriamente dito (Almeida, 2013). O projeto de integração seria um meio para a consolidação da democracia - afastando a tradicional rivalidade fomentada durantes as ditaduras -, para a renegociação da dívida externa em bases mais favoráveis e para a criação de um modelo de desenvolvimento alternativo, intermediário entre a substituição de

\footnotetext{
${ }^{11}$ Ante o anúncio do Plano Bush, em junho de 1990, que propunha pela primeira vez a criação de uma área de livre-comércio hemisférica, a estratégia da diplomacia brasileira consistiu em articular uma resposta conjunta com a Argentina, o Chile e o Uruguai, destacando que a iniciativa norte-americana não poderia contrapor-se aos esquemas de integração em curso no Cone Sul nem cercear as opções de cooperação com outras regiões do mundo. (Mello, 2002:37)
} 
importações praticadas nas décadas anteriores e a liberalização indiscriminada (Vaz, 2002).

Com a eleição dos Presidentes Fernando Collor de Melo e Carlos Saul Menem em 1989, o projeto de integração adquiriu um nova dinâmica. O próprio lugar da integração regional na política externa brasileira foi redimensionado, dada as novas orientações da diplomacia brasileira: atualizar a agenda internacional do país e abandonar posturas defensivas; construir uma agenda positiva com EUA; e descaracterizar o perfil terceiro mundista, com o abandono da clivagem Norte/Sul das décadas anteriores (Hirst e Pinheiro, 1995). Nesse sentido, o processo de integração passava a ser visto como espaço de aprendizado e adaptação para o setor privado, para enfrentar a abertura comercial mais ampla imposta pela globalização dos mercados.

No plano doméstico, os novos governos começavam a implementar a agenda de reforma e abertura da economia e reestruturação do Estado. No âmbito regional, esta reorientação manifestou-se concretamente, por exemplo, na Ata de Buenos Aires, de 6 de julho de 1990 - que antecipou o prazo para a formação de um mercado comum bilateral (até 31 de dezembro de 1994) e substituiu o caráter gradual e flexível, por reduções tarifárias generalizadas, lineares e automáticas e eliminação de barreiras não tarifárias (Almeida, 2013: 121 e 122) - e cujo conteúdo foi reiterado no Tratado de Assunção no ano seguinte.

Segundo Mello, esta redução dos prazos mostrou em certa medida um elemento reativo na formação do Mercosul, como contraponto à formação de outros blocos, principalmente ao NAFTA. Neste sentido, a retomada dos projeto integracionista de Sarney e Alfonsín com um novo formato refletia: 
econômicas domésticas. Ao mesmo tempo, constituíram uma resposta defensiva aos impactos potenciais de outros processos de regionalização e, sobretudo, antecipavam possíveis efeitos que adviriam da formação do Nafta. (Mello, 2002: 37)

É interessante notar que esta reorientação do projeto regionalista não eliminou totalmente os elementos da fase anterior, isso porque, no Brasil, a integração pareceu servir a dois objetivos não necessariamente convergentes: por um lado, ser compatível com os processos de reestruturação do Estado e abertura econômica (e aqui teríamos a centralidade da liberalização comercial), mas também servir como contraponto, ou ainda como fortalecimento da posição da diplomacia brasileira nas negociações hemisféricas frente aos EUA (vide a manutenção da ideia de um mercado comum, com a coordenação de políticas macroeconômicas) ${ }^{12}$. Combinando as medidas da fase SarneyAlfonsín com a nova orientação da fase Collor-Menem, o projeto de integração no Cone Sul passou a exibir uma combinação dissonante entre o objetivo final - a constituição de um mercado comum - e os meios para alcançá-lo - a redução rápida e generalizada de tarifas comerciais. Isto porque a constituição de um mercado comum se configura a partir da adoção de uma tarifa externa comum frente a terceiros países e da livre circulação de fatores produtivos (inclusive de trabalhadores), o que exige certo grau de coordenação de políticas macroeconômicas e de políticas para complementariedade produtiva, de modo a reduzir potenciais impactos negativos da livre circulação. Por sua vez, uma área de livre comércio é menos ambiciosa do ponto de vista da coordenação política e se caracteriza pela eliminação ou redução substantiva de tarifas e de barreiras não tarifárias, mas não afeta a liberdade de relações comerciais e econômicas com terceiros países. Neste sentido, a rápida liberalização comercial, sem a coordenação de políticas econômicas como

\footnotetext{
${ }^{12}$ De fato, o formato e a evolução posterior do processo de integração sub-regional instaurado em 1990 demonstraram que, embora os marcos gerais do projeto inicial de política externa do governo Collor estivessem voltados para a aproximação e a convergência com as posições dos Estados Unidos, a diplomacia brasileira encontrou no Mercosul um espaço para uma atuação internacional independente do eixo central nas relações com Washington. (Mello, 2002:38)
} 
contrapartida, coloca em evidencia esta disjunção entre o objetivo anunciado e instrumentos adotados para alcançá-lo. As ambiguidades deste processo, tratadas na fase inicial do bloco com arranjos temporários e listas de exceção, mostrar-se-ão cada vez mais presentes, com a recorrência de conflitos comerciais.

Embora a década de oitenta tenha testemunhado o florescimento de organizações da sociedade civil brasileira, inicialmente as amplas mobilizações estiveram dissociadas de temas internacionais, como mencionado anteriormente. A principal exceção veio do movimento sindical, com a criação da Coordenadora de Centrais Sindicais do Cone Sul (CCSCS) que, embora não tivesse a integração entre suas razões iniciais, mostrar-se-ia um dos principais atores da sociedade civil ao longo dos anos noventa no plano regional. Formada em $1986^{13}$, no contexto da redemocratização, com apoio da CIOLS/ORIT (Confederação Internacional de Organizações Sindicais Livres/Organização Regional Interamericana de Trabalhadores), os principais objetivos da CCSCS eram apoiar as transições democráticas no Cone Sul, especialmente no Chile e no Paraguai, e desenvolver ações comuns contra o pagamento das dívidas externas de seus países (Mariano, 2011; Von Büllow, 2010). Inicialmente, a CCSCS não voltou suas atenções para o que seria no futuro o Mercosul. Enquanto o Tratado de Integração de 1988 era visto como um conjunto de intenções a serem negociadas e aplicadas no longo prazo, não houve uma mobilização por parte dos grupos sociais nacionais. Somente com a intensificação do processo de integração regional, cujo marco foi a assinatura do Tratado de Assunção, houve uma consolidação da CCSCS (Castro apud Mariano, 2011: 104)

\footnotetext{
${ }^{13}$ Os integrantes iniciais da CCSCS eram: CUT e CGT no Brasil; CGT na Argentina; CUT no Paraguai; e PIT/CNT no Uruguai.

A origem da CCSCS remetia às relações entre sindicalistas brasileiros e uruguaios, quando exilados uruguaios ligados ao PIT-CNT estabeleceram uma "coordenação sindical" em 1982, que funcionava em São Paulo, com apoio de sindicalistas ligados ao movimento que formaria a CUT no ano seguinte (Von Büllow, 2010: 59)
} 
No restante deste capítulo veremos o contexto das negociações diplomáticas e dos aspectos políticos e econômicos dos acordos regionais, da assinatura do Tratado de Assunção ao fim das negociações da ALCA -, bem como a percepção e as respostas das organizações da sociedade civil frente a este cenário.

\section{Do Tratado de Assunção ao lançamento oficial das negociações da} ALCA: mobilização e participação do movimento sindical

Esta primeira fase pode ser subdividia em dois períodos, que compreendem a etapa de transição (da assinatura do Tratado de Assunção, em março de 1991, ao Protocolo de Ouro Preto, em dezembro de 1994) e o início da união aduaneira propriamente dita a partir de $1^{\circ}$. de janeiro de 1995. O período de transição foi caracterizado pela incorporação oficial do Paraguai e do Uruguai nas negociações, pelos impasses com relação à manutenção do cronograma inicial e pela frequência de conflitos comerciais resolvidos por meio de arranjos temporários, que tornar-se-iam uma marca registrada do bloco.

O período de transição e a atuação nos subgrupos de trabalho

Depois da Ata de Buenos Aires, o Paraguai e o Uruguai, que já acompanhavam como observadores, foram oficialmente convidados a participar da formação do Mercosul (Mariano, 2011: 52). O Tratado de Assunção, assinado em março de 1991, estabeleceu um cronograma de ações para o período de transição, que previa inicialmente a desgravação tarifaria, a harmonização de políticas macroeconômicas e a negociação de uma tarifa externa comum (TEC) frente a terceiros mercados.

Durante a maior parte do período de transição, Argentina e Brasil tiveram divergências cambiais importantes. Neste período, a Argentina adotou um plano de estabilização da moeda, que estabeleceu uma taxa de cambio 
fixa com relação ao dólar, em 1991, e a paridade a partir de 1992. O Brasil adotava então uma política de permanente desvalorização cambial, que permitia o crescimento de suas exportações aos demais parceiros do bloco, mas gerava constantes atritos com a Argentina devido aos desequilíbrios na balança comercial que causava ao país vizinho. Já no final de 1992, as negociações enfrentavam dificuldades devido às diferenças entre a politica de estabilização argentina e a alta inflação no Brasil, além de grandes diferenças nos patamares tarifários. As negociações da TEC tiveram início neste ambiente de conflitos, que só seriam parcialmente superados a partir da estabilização da moeda e da inflação no Brasil, com o Plano Real, em 1994.

Apesar das dificuldades e da falta de coordenação de políticas macroeconômicas entre os dois maiores sócios, na II reunião do CMC em Las Leñas, em junho de 1992, os quatro governos decidiram manter o prazo final estipulado pelo Tratado de Assunção para o início da vigência do mercado comum. Contudo, na V reunião do GMC, em Colonia, em janeiro de 1994, os governos revisaram os prazos e definiram objetivos mais modestos: ficou decidido que os esforços em relação ao Mercosul concentrar-se-iam no estabelecimento de uma união aduaneira (Mariano, 2011: 140). A partir da avaliação de que o protocolo de Las Leñas fora muito ambicioso, os governos estabeleceram um novo período de transição para a formação do mercado comum (inicialmente previsto para 2001 e pposteriormente adiado). As medidas para a harmonização das políticas macroeconômicas e a adoção de uma estrutura institucional supranacional foram adiadas. As divergências setoriais e as desvantagens comparativas apontadas pelos sócios menores foram solucionadas com medidas temporárias. No ano anterior as negociações já apontavam para uma mudança importante na pretensão inicial de harmonização das políticas produtivas: os subgrupos de política industrial e de política agrícola foram esvaziados e as representações empresariais e sindicais 
não participaram e não tiveram acesso às negociações para a definição da TEC e das regras de controle de origem (CUT, 1996; 2000).

Com relação às organizações da sociedade civil, a fase de transição se caracterizou pela atuação quase exclusiva do movimento sindical, que embora, ainda não tivesse uma estratégia clara de participação, buscou incidir nos rumos do processo a partir do fortalecimento da Coordenadora de Centrais Sindicais do Cone Sul ${ }^{14}$. Embora os países do Cone Sul contassem com ampla mobilização da sociedade no contexto da redemocratização, poucas organizações da sociedade civil se interessaram inicialmente pelo projeto regionalista. Registros apontam a organização de alguns seminários e debates sobre o tema, como o seminário "Mercosul ou a integração dos povos do Cone Sul? ${ }^{15}$ ",

\footnotetext{
${ }^{14}$ Vale destacar que, nesta fase inicial, as centrais não tinham uma posição unitária sobre o tema: tanto o Plenario Intersindical de Trabajadores - Convención Nacional de Trabajadores (PIT-CNT, Uruguai), quanto a Central Única dos Trabalhadores (CUT, Brasil) contavam com minorias importantes que se opunham ao Mercosul, pois acreditavam que a lógica neoliberal era inerente ao processo. No PIT-CNT, a opção de apoio crítico ganhou a votação por pequena margem frente à alternativa de se opor ao acordo. Um debate similar aconteceu na CUT, embora a oposição fosse um pouco mais fraca, devido à influência que o PIT-CNT tivera na posição da central (Von Büllow, 2010: 61)

${ }^{15}$ A publicação resultante do seminário indica a participação de 30 entidades sindicais, populares, de pesquisa e assessoria, provenientes da Argentina, Brasil, Chile e Uruguai. A declaração final já mostra a presença de elementos que serão comuns no discurso alternativo da integração: $O$ desejo e a necessidade de integração cultural e política dos povos da América Latina, expressos de diversas formas, desde Bolívar, não são, porém, o elemento motivador desta iniciativa [Mercosul]. Os governos e as elites do Cone Sul têm pressa em "chegar ao Primeiro Mundo". Num momento em que o hemisfério norte se reestrutura, mediante organização de macromercados de centenas de milhões de "consumidores", (...) os governos e as elites do Cone Sul se excitam com a ideia de preparar caminho para que a Iniciativa para as Américas, do presidente norte-americano George Bush, se torne realidade. O Mercosul foi criado para servir como passo introdutório àquela meta. Sua criação e implementação são obra dos governos e dos grandes grupos econômicos, sem que tenha havido um debate democrático que envolvesse todos os setores por ele afetados.

(...) Nesse contexto em nossas organizações - centrais sindicais, entidades sindicais e populares, igrejas, organizações não-governamentais, universidades e governos municipais dos países do Cone Sul - constatamos que fazemos parte de um MOVIMENTO PELA INTEGRAÇÃO DOS POVOS DO CONE SUL DA AMÉRICA LATINA (...) O primeiro objetivo do movimento seria trabalhar pela democratização da informação a respeito das negociações do Mercosul, do Acordo Brasil-Argentina, do Acordo Chile-México e todo outro entendimento que vise a integração da sub-região. É preciso estabelecer um amplo debate público a respeito deles em cada país e criar as condições para que as organizações da sociedade civil participem efetivamente nas negociações globais e especificas. (Arruda, Gonçalves, Prado, 1992: 69-72)
} 
promovido pelo Instituto Políticas Alternativas para o Cone Sul $\left(\mathrm{PACS}^{16}\right)$, a Federação de Órgãos para Assistência Social e Educacional (FASE) e a UFRJ, em dezembro de 1991 em Porto Alegre; e um seminário promovido pelo Setor Pastoral Social da Confederação Nacional dos Bispos do Brasil (CNBB), em setembro de 1992 em Curitiba ${ }^{17}$.

As declarações e documentos produzidos nestas atividades mostram em geral um posição crítica à integração regional e articulam elementos que serão centrais ao discurso alternativo de integração que, ao longo da década de 1990, será construído por movimentos sindicais e sociais, ONGs e partidos políticos de esquerda em torno da contraposição entre um projeto neoliberal de integração (proposto por governos e elites econômicas) e um projeto de integração dos povos, que fosse além da dimensão comercial, com a inclusão das dimensões política, social e cultural, com uma perspectiva solidária, que não fosse regida pelos interesses de grandes grupos econômicos e que incluísse mecanismos de consulta às organizações da sociedade civil.

As centrais sindicais, por sua vez, foram as organizações com atuação mais sustentada e constante nas instâncias institucionais da integração, ainda que inicialmente com propostas vagas, unidas em torno de demandas pela valorização da dimensão social no processo regional e pela criação de espaços de participação e consulta à sociedade. Em estudo aprofundado sobre a atuação sindical no Mercosul, Karina Pasquariello Mariano destaca que a negociação transnacional não fazia parte da agenda interna tradicional do movimento sindical, o que exigiu

\footnotetext{
${ }^{16}$ A iniciativa partiu de um grupo de economistas que retornavam do exílio a seus países de origem: Argentina, Brasil, Chile e Uruguai. Foi fundado em 1986 como parte brasileira do PRIES - Programa Regional de Investigações Econômicas e Sociais para o Cone Sul da América Latina -, a partir de divergências políticas no lbase.

${ }^{17}$ Segundo o informe publicado sobre o seminário, participaram membros das pastorais sociais e de outros organismos da Igreja, centros de pesquisa, professores universitários e representantes da Argentina, Paraguai e Uruguai. Refletindo sobre o Mercosul, constataram unanimemente a necessidade urgente de toda a sociedade civil participar dessa reflexão, para que este projeto seja melhor conhecido, em vista de ser colocado a serviço da verdadeira integração dos povos latino-americanos. (Almeida, 1998: 167)
} 
das centrais uma adaptação à lógica da cooperação e da integração regional. Essa adequação sindical ao processo de integração não foi automática e dependeu da capacidade de cada central se ajustar às realidades e necessidades embutidas nessa nova esfera de participação. Dentro deste processo, a CUT Brasil e a CGT argentina foram os atores mais relevantes. Embora os movimentos sindicais ainda não contassem com uma pauta de reivindicações bem definida, a percepção foi de que seria mais prejudicial não participar e, desse modo, buscaram garantir espaço nas negociações, mesmo antes de definir seus objetivos com precisão (Mariano, 2011:13,14).

Ainda de acordo com a autora:

\begin{abstract}
A iniciativa de integração econômica dos governos dos quatro países desencadeou uma reação no sindicalismo da região, que se viu atropelado por um processo do qual não fazia parte e que até então não Ihe despertava interesse. (...) Em vista disso, as centrais sindicais reivindicaram um espaço de intervenção nas negociações do Mercosul, baseando seu pedido na necessidade de participação dos atores sociais, enfatizando que o processo, da forma como estava sendo desenvolvido, era antidemocrático e excluía a sociedade. (Mariano, 2011: 15)
\end{abstract}

Em 1991, a CCSCS fez seu primeiro pronunciamento público sobre o recém criado Mercosul com a seguinte avaliação: "o compromisso sindical com a integração existe desde que este processo traga avanços nas dimensões social, política e cultural dos quatro países e que a transformação da estrutura produtiva não se dê em prejuízo dos trabalhadores e do conjunto dos setores populares" (CUT, 2000: 53). A posição evidencia uma crítica à forma de condução do processo, mas com apoio ao potencial da integração para o desenvolvimento regional ${ }^{18}$.

\footnotetext{
${ }^{18}$ Segundo Mariano, nesta fase de transição a CCSCS propunha uma projeto alternativo de integração suficientemente amplo para permitir que os diferentes interesses das centrais pertencentes se sentissem contemplados, o ponto de acordo era que a integração regional tal como estava sendo realizada pelos governos favorecia os interesses econômicos em detrimento das questões sociais, mas que, potencialmente, a integração regional poderia ser elemento positivo na promoção do desenvolvimento (Mariano, 2011:106)
} 
Os sindicatos foram os primeiros movimentos a acompanharem de forma sistemática as negociações no âmbito do Subgrupo de Trabalho sobre relações trabalhistas e seguridade social $\left(\mathrm{SGT}-11^{19}\right)$. O SGT-11, que não existia originalmente no Tratado de Assunção, teve sua criação aprovada na reunião do CMC realizada em Brasília, em 1991, por recomendação dos ministros do trabalho e contou com pressão e apoio das centrais sindicais. O subgrupo deveria realizar um estudo técnico comparado e elaborar propostas de harmonização das legislações e superação das assimetrias das legislações, visando a igualdade de condições a todos os cidadãos do Mercosul (sugestões que não seriam contempladas no Protocolo de Ouro Preto, como veremos adiante). Até 1994, os sindicatos acompanharam as negociações do subgrupo como observadores e, após este período sua participação passou a ser institucionalizada, embora sem poder de decisão.

Com a manutenção do cronograma original na reunião de Las Leñas, que implicou uma agenda ampla e com prazos curtos nas instâncias técnicas como os subgrupos de trabalho - as centrais sindicais se viram enredadas em debates de aspectos técnicos em detrimento das questões sociais e políticas, aumentando ao mesmo tempo o peso dos órgãos governamentais e fazendo com que a participação sindical fosse pautada pelos temas dos governos. (Mariano, 2011: 60)

Em 1994, a CCSCS apresentou uma proposta inicial para a adoção de uma Carta Social do Mercosul, baseada em convenções da OIT e em alguns aspectos da Carta Social Europeia, que como veremos só seria parcialmente adotada em 1998. Esta demanda se fundamentava na compreensão de que o Mercosul realmente viria a constituir-se como um

\footnotetext{
${ }^{19}$ Os subgrupos de trabalho são instâncias subordinadas ao Grupo Mercado Comum, encarregadas de analisar e propor decisões sobre todas as questões relacionadas com a integração, com exceção dos temas aduaneiros que correspondem à Comissão de Comércio do Mercosul. Atualmente há 17 SGTs na estrutura do bloco.

Em 1996, o SGT-11 é rebatizado como Subgrupo de Emprego, Relações Trabalhistas e Seguridade Social (SGT10).
} 
mercado comum, com livre circulação de bens, serviços, capitais e força de trabalho, o que colocava a demanda por garantia de alguns direitos trabalhistas e sociais básicos. Por ocasião da Cúpula de Ouro Preto, em 1994, a CCSCS enviou uma carta pública aos presidentes, na qual refletia sobre os impactos sociais do crescimento da interdependência; alertava para o crescimento do desemprego; criticava a falta de atenção ao aprofundamento de desequilíbrios entre os membros - sem a adoção de política compensatórias; reivindicava a adoção de uma carta de direitos fundamentais, de normas básicas de saúde e segurança no trabalho, a regulamentação de mecanismos para a negociações coletivas regionais; e a criação de um fórum econômico e social, que permitisse uma participação ampliada da sociedade (CUT, 2000).

A reivindicação de direitos em âmbito supranacional revela a expectativa de que o Mercosul viria a constituir-se como um mercado comum, com possíveis instituições supranacionais:

The fact that Mercosur was proposed as a future commom Market, and not merely as the creation of a free trade area, gave labor organizations a horizon of many years of negotiation on delicate issues such as labor mobility, a process they felt could not be excluded from. (Von Büllow, 2010: 60)

Contudo, a redefinição dos objetivos na reunião do GMC em Colonia e a ênfase comercial dada ao Mercosul, em detrimento da coordenação de políticas macroeconômicas, foi progressivamente minando o projeto de complementariedade produtiva. A diminuição da velocidade da integração acabou ocasionando um parcial esvaziamento do SGT-11. A reivindicação de uma Carta Social do Mercosul teve pouca ressonância: nesta altura, o horizonte do mercado comum ficava mais distante frente aos arranjos temporários e listas de exceção para acomodar as discordâncias com relação à própria união aduaneira. 
O início da união aduaneira e a criação do Fórum Consultivo Econômico e Social

Apesar das dificuldades de coordenação política do período de transição, a assinatura do Protocolo de Ouro Preto, em dezembro de 1994 deu forma institucional à união aduaneira imperfeita que entrou em vigor em $1^{\circ}$. de janeiro de 1995 . O desenho institucional adotado refletiu uma perspectiva integralmente intergovernamental, concentrada nos executivos nacionais, em particular em alguns setores do governo, sobretudo nas chancelarias, que são responsáveis pela coordenação das reuniões dos órgãos com poder decisório ${ }^{20}$. Conforme indica Caetano, Vázquez e Ventura (2008), em artigo sobre reforma institucional no Mercosul, esta concentração de poder abarca inclusive trâmites administrativos ordinários, de modo que, entre os organismos intergovernamentais existentes, o Mercosul é um dos processos negociadores que apresenta o menor grau de densidade institucional. Também é expressiva a concentração de poder no Estado que exerce a Presidência Pro Tempore (PPT), influenciando fortemente a pauta de negociação e a ordem do dia das reuniões e estabelecendo uma relação direta entre a qualidade de uma PPT e a dinâmica institucional do bloco (Caetano, Vázquez e Ventura, 2008). Paralelamente a esta concentração, adotou-se uma estratégia de proliferação dos espaços de negociação sem poder de decisão (reuniões de ministros, reuniões especializadas, subgrupos, comitês, grupos ad hoc), vinculados ao CMC e GMC

\footnotetext{
${ }^{20}$ Artigos 7, 11 e 17 do Protocolo de Ouro Preto. O Protocolo de Outro Preto definiu três instituições com poder decisório: o Conselho Mercado Comum (CMC), o Grupo Mercado Comum (GMC) e a Comissão de Comércio do Mercosul (CCM). O CMC é a instância superior do Mercosul, responsável pela condução política do processo de integração e a tomada de decisões para assegurar o cumprimento dos objetivos estabelecidos pelo Tratado de Assunção e para lograr a constituição final do mercado comum (Protocolo de Ouro Preto, 1994). É integrado pelos ministros das relações exteriores e da economia e deve se reunir no mínimo uma vez por semestre, com a presença dos Presidentes dos Estados parte. O CMC toma decisões por consenso e se pronuncia por meio de decisões, de caráter obrigatório. $\mathrm{O}$ Grupo Mercado Comum é o órgão executivo do bloco, se pronuncia por meio de resoluções e é integrado por quatro membros titulares e quatro membros alternos por país, dentre os quais devem constar necessariamente representantes do MRE, do Ministério da Economia e dos Bancos Centrais. A Comissão de Comércio é o órgão encarregado de assistir o Grupo Mercado Comum com relação à aplicação dos instrumentos de política comercial comum no comércio intra-Mercosul e com terceiros países. A CCM se pronuncia mediante diretrizes ou propostas.
} 
(Caetano, Vázquez, Ventura, 2008). Além das instâncias decisórias, o Protocolo de Ouro Preto estabeleceu também um órgão técnico, a Secretaria Administrativa (renomeada Secretaria do Mercosul), e dois órgãos consultivos: a Comissão Parlamentar Conjunta (sucedida pelo Parlamento Mercosul) e o Fórum Consultivo Econômico e Social, como espaço de consulta aos setores sindicais, empresariais e ao chamado terceiro setor, que no caso do Mercosul seria majoritariamente representado por cooperativas organizadas e por órgãos de defesa do consumidor.

$\mathrm{Na}$ fase posterior à assinatura do Protocolo de Ouro Preto, o Mercosul ficou praticamente estagnado e já dava mostras das crises institucionais que seriam mais fortes e frequentes a partir de 1999. Apesar de imperfeita, a entrada em vigor da união aduaneira gerou um crescimento expressivo da interdependência, sem instituições fortes para gerenciá-la: un mercado ampliado a ritmos acelerados, sin instituciones ni políticas efectivas para la integración, no podia sino desembocar en una creciente conflictividad y en la perforación de las medidas y acuerdos alcanzados (Caetano, 2011: 36)

Segundo Mello (2002:40), as dificuldades crescentes e os atritos constantes foram causados por alguns fatores, dentre os quais a própria complexidade da agenda após a fase de eliminação automática de tarifas; as assimetrias na orientação de política econômica por parte dos principais membros - o que levou a uma menor disposição para assumirem compromissos que restringissem a autonomia - e o contexto de fragilidade macroeconômica e vulnerabilidade externa agravadas pela instabilidade nos mercados financeiros em 1997 e 1998 (com as crises asiática e russa). Estas debilidades se manifestaram na morosidade da implementação das decisões tomadas em Ouro Preto e na própria agenda do bloco, cujas reuniões se viram diminuídas no período. 
As tentativas do movimento sindical, por meio da CCSCS, de incidir sobre os rumos da integração na fase de transição tiveram pouca influência em Ouro Preto. As duas sugestões concretas formuladas no âmbito do SGT11 -a ratificação de trinta e cinco convenções da OIT e a adoção de um acordo multilateral de previdência - não foram contempladas. A única inovação do Protocolo com relação às organizações da sociedade civil foi a criação do FCES, sobre o qual o Protocolo foi extremamente vago, concebendo-o como o órgão de representação dos setores econômicos e sociais $^{21}$. O regimento interno determinou que o FCES fosse composto por nove delegados por país (e seus suplentes), mas concedeu autonomia para as seções nacionais decidissem sua composição, observando que as organizações fossem as mais representativas e que houvesse paridade entre organizações de trabalhadores e empresários ${ }^{22}$.

Após Ouro Preto, o ritmo de participação foi reduzido, devido a um momento de balanço dos resultados (não) alcançados na fase de transição, à própria diminuição do ritmo das reuniões por parte dos governos (não foi convocada nenhuma reunião do SGT-11 em 1995, por exemplo) e, no caso brasileiro, na intensificação do programa de ajustes econômicos por parte do governo, que afetava fortemente a agenda sindical. Avaliando sua participação, a CUT diagnosticou o erro de seguir a agenda governamental de negociação na fase de transição e a falta de mobilização e articulação com outros setores da sociedade civil, que potencialmente teriam sido aliados em algumas reivindicações, como a carta social (Mariano, 2011: 113, 148).

\footnotetext{
${ }^{21}$ artigo 28 de Protocolo de Ouro Preto. Concretamente, o FCES ainda não faz menção propriamente à sociedade civil, de modo que, na prática, os "setores econômicos e sociais" são basicamente os sindicatos e os empresários (semelhante ao Comitê Econômico e Social da União Europeia).

${ }^{22}$ No Brasil, integram a seção nacional: Central Autônoma de Trabalhadores, Central Única dos Trabalhadores, Confederação Geral dos Trabalhadores, Força Sindical, Confederação Nacional da Agricultura, Confederação Nacional do Comércio, Confederação Nacional da Indústria, Confederação Nacional do Transporte, Federação Nacional das Empresas de Seguros Privados e de Capitalização, Instituto Brasileiro de Defesa do Consumidor e Sociedade Brasileira para o Progresso da Ciência
} 
Considerando este balanço crítico e a perspectiva de uma nova instância consultiva com o FCES, a CCSCS passou a adotar uma abordagem mais pragmática que, a partir de $1996^{23}$, será centrada na implementação efetiva do Fórum Consultivo Econômico e Social (que ainda precisava ser regulamentado e aprovar seu regimento), na reivindicação de um protocolo para a harmonização de direitos sociais e trabalhistas e de um observatório sobre o mercado de trabalho nos quatro países ${ }^{24}$ (CUT, 2000). No plano organizativo, começaram a funcionar as comissões sindicais setoriais ${ }^{25}$, que reuniam no âmbito da Coordenadora setores específicos, com o objetivo de debater os impactos do bloco recém formado, acompanhar os SGTs e formular reivindicações.

As negociações específicas de um instrumento de garantia de direitos sociais e trabalhistas começaram efetivamente em 1997, marcadas por forte divergência quanto à sua força jurídica. Os setores sindicais defendiam a adoção de um protocolo, que teria portanto um caráter obrigatório e força de lei. Os empresários por sua vez se opunham a uma série de reivindicações, como a obrigatoriedade de formalização de contratos de trabalho e a delimitação da jornada de trabalho e recusavam qualquer regulamentação de negociações coletivas supranacionais. $O$ impasse foi solucionado com uma proposta brasileira que determinava a adoção de uma Declaração (portanto sem força legal), mas contemplava a criação de uma comissão sócio-laboral tripartite que, ao termino de dois anos, poderia reformular a declaração (CUT, 2000). Embora a Declaração

\footnotetext{
${ }^{23}$ Em 1996, o SGT-11 é rebatizado como Subgrupo de Emprego, Relações Trabalhistas e Seguridade Social (SGT10)

${ }^{24}$ Segundo Mariano (2011: 155), já com uma postura pragmática em torno de demandas mais pontuais, no início de 1996, as centrais manifestaram sua insatisfação com a falta de resultados ameaçando abandonar as reuniões. Embora, os governos não tivessem sido particularmente abertos às reivindicações sindicais até então, a participação era um instrumento de legitimação, inclusive perante as negociações com outros blocos, de modo que a ameaça surtiu alguns (poucos) efeitos no período subsequente.

${ }^{25}$ Funcionavam as seguintes comissões sindicais setoriais no âmbito da CCSCS: metalúrgicos, bancários, transportes, construção civil, têxteis e confecções, laticínios, papel e celulose e gráficos
} 
Sócio-Laboral do Mercosul ${ }^{26}$, aprovada em 1998, tenha sido uma das poucas demandas sindicais atendidas ${ }^{27}$ (junto com a criação do Observatório Mercado de Trabalho), a vitória foi parcial, na medida em que não foi possível garantir o caráter vinculante do novo instrumento (e não houve até o momento sua reformulação, como prevista originalmente).

Além da atuação na esfera institucional, o movimento sindical também promoveu mobilizações sociais importantes, como a organização de comemorações do $1^{\circ}$. de maio nas fronteiras (dois na fronteira BrasilUruguai, entre Santana do Livramento e Rivera, o primeiro deles em 1995). Neste momento, as negociações da ALCA já ofereciam também um elemento para a mobilização de repertórios mais contenciosos (que será mais evidente na fase seguinte), com a organização de cúpulas sindicais paralelas às reuniões oficiais de presidentes e a organização de manifestações e marchas por ocasião das Cúpulas de Presidentes do Mercosul.

Nossa ideia era que a participação institucional em si não resolveria, teria que ter um processo de visibilidade e de mobilização. Optamos por, em alguns momentos-chave, tentar um processo de pressão popular, em alguns casos, aliado à luta contra a ALCA.

(...) a gente chamava para cúpula sindical paralela, muito parecida à cúpula dos povos, cúpula social. A gente juntava todos os esforços nas diversa áreas de atuação da Coordenadora e chamava um grande encontro paralelo à cúpula oficial. Neste grande encontro discutíamos fortemente (...) e quando possível fazíamos marchas. Geralmente as

\footnotetext{
${ }^{26}$ A Declaração reconhece uma série de direitos individuais (igualdade, não discriminação, liberdade de associação, liberdade sindical) e coletivos (direito à greve, negociações coletivas). A Declaração recomenda ainda a criação da Comissão Sócio-Laboral como organização tripartite, com caráter promocional e não punitivo.

27 Revisando a ação sindical, suas demandas e participação nas esferas institucionais, Mariano sintetiza algumas conquistas do período: além da Declaração Sócio-Laboral, a participação sindical passa a ser formalmente reconhecida no âmbito do SGT-10 (sem poder de decisão, mas não mais como observador) e houve a diminuição no número de comissões deste subgrupo (de oito para três), que facilitou o acompanhamento das discussões. Em 1997, o Mercosul aprovou o acordo multilateral de previdência social e a partir da entrada em vigor em 2005 passou a reconhecer direitos de aposentadoria idênticos aos trabalhadores que prestem ou tenham prestado serviços em qualquer país do bloco. No início de 1999, a Volkswagen assinou o primeiro acordo coletivo regional, materializando uma reivindicação antiga do movimento sindical em torno de negociações coletivas supranacionais (2011: 157160, CUT, 2000)
} 
marchas iam até a primeira barreira policial. Em Fortaleza a repressão foi muito forte, não chegamos nem perto do evento, soltaram bomba dos helicópteros ${ }^{28}$.

Aliado à participação nas instâncias institucionais, o uso de repertórios de protesto no Mercosul, como o ato em Fortaleza, repertir-se-ia nas seguintes cúpulas de Presidentes realizadas no Brasil (Rio em 1998, Florianópolis em 2000) e também em outros países.

Embora até os anos 2000, as organizações ligadas aos empresários e aos trabalhadores permanecessem como os atores com participação mais frequente e institucionalizada, outros setores da sociedade civil estiveram presentes na fase iniciada com a assinatura do Protocolo de Outro Preto, embora de forma menos sustentada. Há registros sobre a participação de movimentos de mulheres em torno da criação da Reunião Especializada da Mulher, de ambientalistas no Subgrupo 6 e de agricultores familiares no SGT8.

O movimento de mulheres não se incorporou de modo ativo no Mercosul desde o início. Em parte isto se deveu aos esforços então direcionados às discussões preparatórias à Conferência Mundial sobre a Mulher, que ocorreu em 1995, em Beijing: la preocupación por el Mercosur quedó fuera de estos ámbitos, reconociéndose la falta de fuerza para desarrollar acciones paralelamente en esa esfera institucional, con toda su complejidad de actores e instancias. (Valdés, 2003: 259). Segundo Valdés, o Fórum de ONGs da América Latina e Caribe, que se reuniu em Mar del Plata em 1994, numa reunião preparatória para Beijing, não considerou ou propôs que o movimento de mulheres assumisse qualquer papel no processo regional. A autora relata ainda a organização de dois seminários internacionais "Mulher e Mercosul" em São Paulo, em 1995 e 1997, que reuniram funcionários governamentais, parlamentares, pesquisadoras, sindicalistas e ativistas do movimento de mulheres. $O$

\footnotetext{
${ }^{28}$ Entrevista com Rafael Freire Neto, atualmente integrante do Secretariado Executivo da Confederação Sindical das Américas e ex-Secretário de Relações Internacionais da CUT
} 
primeiro deles, em $1995^{29}$, estabeleceu uma rede de troca de informações, mas não explicitou uma proposta de incidência sobre o tema ou de presença de mulheres nas instancias oficiais do Mercosul.

O segundo seminário ${ }^{30}$, em 1997, teve como um dos resultados a proposta de criação da Reunião Especializada da Mulher no Mercosul (REM), aprovada no ano seguinte (Valdés, 2003: 263). Mas o tema foi promovido menos por movimentos sociais de mulheres ${ }^{31}$ e mais pelo Foro de Mulheres do Mercosul, uma ONG integrada por representantes de partidos políticos, empresarias e funcionarias de governo, que por meio de sua ação nas burocracias governamentais conseguiu ser reconhecida como órgão assessor da REM, em 1998. Uma vez em funcionamento, o espaço ganhou certa visibilidade e despertou a atenção de movimentos feministas que buscaram sua incorporação ${ }^{32}$. (Valdés, 2003: 265). A autora destaca também o papel das mulheres sindicalistas, que começaram a articular sua participação, a partir de uma perspectiva de gênero, no âmbito da CCSCS em 1997.

Os movimentos ambientalistas tiveram pouquíssima participação institucionalizada e quase nenhuma influência neste período. Segundo Hochstetler (2003:212), as próprias instituições do Mercosul dificultavam a presença da temática ambiental, já que o principal canal representativo, o FCES privilegiava a participação de sindicatos e empresas, contribuindo para a desigualdade de oportunidades. Ambientalistas chegaram a participar do SGT6, que se reuniu pela primeira vez em outubro de 1995,

\footnotetext{
${ }^{29}$ organizado pela FLACSO, com apoio da UNIFEM, Parlatino, BID, Fundação Memorial América Latina, British Council, Fundação Fullbright, UNIDO e OIT

${ }^{30}$ organizado por Unifem, Conselho Nacional para os Direitos da Mulher do Brasil, Parlatino, cooperação espanhola, OIT, FES, Comissão de Comunidades Europeias

31 Ainda segundo Valdés (2003:264): Ocupados en otras cosas, los movimientos y organizaciones feministas comprometidos y activos en el proceso Beijing y en el seguimiento de las cumbres y conferencias mundiales de la década de los noventa, han estado ausentes de esta instancia, es decir, no han sido convocados ni han intentado estar presentes - al menos en una primera etapa - en la REM.

${ }_{32}$ Atualmente os seguinte movimentos são órgãos assessores da REM: Foro de Mulheres do Mercosul, Articulação Feminista Marcosul, CLADEM, Comissão de Mulheres da CCSCS, Rede Internacional de Gênero e Comércio (IGTN)
} 
mas também neste caso a abertura à participação do "setor privado" privilegiava o organizações industriais, em detrimento dos movimentos ambientalistas. Além do viés pró-empresarial no STG-6, a falta de informações e recursos dificultava uma presença mais constante. Algumas ONGs internacionais (como a WWF e a Fundação Rockfeller) e o BID apoiavam financeiramente a participação de ambientalistas no Mercosul, mas em linhas gerais, poucas organizações participavam do SGT-6 e somente o faziam quando havia algum tema de interesse na agenda (Hochstetler, 2003:219).

Organizações ligadas à agricultura familiar, por sua vez, tentaram se articular no período do Protocolo de Ouro Preto. Algumas entidades de pequenos produtores rurais da Argentina e do Uruguai participavam das reuniões do SGT-8 (sobre agricultura), mas sem sucesso em incluir a pauta da agricultura familiar e a necessidade de políticas específicas para este setor. A falta de influência fez com que estas entidades buscassem se articular com organizações similares dos outros países do bloco e, em 1994, organizações dos quatro países (mais Chile e Bolívia) criaram a Confederação de Organizações de Produtores Familiares do Mercosul (COPROFAM) - que naquele momento buscava influenciar os debates no SGT8, mas que praticamente não teria influência até 2003 , com a criação de uma instância específica sobre agricultura familiar. A Coprofam conseguiu participar de alguns seminários (Seminários Agroindustriais) e de algumas reuniões quadripartites (com representantes das organizações e dos quatro Estados), mas sem que os debates ali travados chegassem à pauta do SGT-8 (Carvalho, 2011:57). Fora das instâncias institucionais, o Instituto de Estudos Socioeconômicos (Inesc) organizou dois seminários, em 1993 e em 1995, com parlamentares, negociadores e organizações da sociedade civil para discutir os eventuais impactos negativos do Mercosul para a agricultura familiar (Riella, 2002).

A consolidação da CCSCS e sua atuação em torno do Mercosul iluminam alguns elementos importantes para a análise da interação entre o plano 
doméstico e regional como estruturas de oportunidades políticas para a ação coletiva transnacional. Como dito anteriormente, a CCSCS fora constituída em 1986 em torno dos processos de redemocratização do Cone Sul, mas foi a ação das centrais em torno do Mercosul que possibilitou sua consolidação como uma coalizão transnacional, cuja estratégia compartilhada foi a adoção de uma postura de apoio crítico ao projeto integracionista, centrada menos em propostas concretas e mais no rechaço à centralidade da perspectiva liberal-comercial e à falta de mecanismos de consulta à sociedade. $O$ apoio crítico não foi comum ${ }^{33}$ entre os sindicatos que se mobilizaram em torno de outros blocos regionais (as pressões por competitividade e o temor da perda de postos de trabalho fazem com que a colaboração não seja um resultado óbvio). A construção do discurso da CCSCS aponta para a integração produtiva, com coordenação de políticas macroeconômicas e setoriais, e para a adoção de mecanismos supranacionais de proteção social e trabalhista, como elementos positivos para a superação da dependência econômica internacional. Ao estudar os antecedentes da coalizão hemisférica que formar-se-ia no final da década, Von Büllow comenta esta peculiaridade do Mercosul:

In the Mercosur case, labor organizations argued the the integration process coul be an effective means of guaranteeing less dependence for the region in the international system. This is precisely the reverse of the framing used by the CLC and by Mexican FAT, which portrayed the integration in North América trough Nafta as a threat to their countries' national sovereignty and domestic growth. (Von Büllow, 2010: 60)

Nos trabalhos revisados e nas entrevistas feitas, vemos que as instâncias do bloco eram percebidas pelo movimento sindical como uma arena adicional às disputas domésticas no contexto de reforma do Estado e abertura econômica ${ }^{34}$. Neste sentido, por um lado, a CCSCS buscava agir de forma a incidir sobre os rumos da integração, tentando evitar que a

\footnotetext{
33 Entrevista com Rafael Freire Neto, atualmente integrante do Secretariado Executivo da Confederação Sindical das Américas e ex-Secretário de Relações Internacionais da CUT ${ }^{34}$ Entrevista com Rafael Freire e com Maria Silvia Portela de Castro, ex-assessora da SRICUT
} 
dimensão regional pudesse criar novos constrangimentos à atuação dos movimentos sindicais em seus contextos domésticos, mas simultaneamente, buscava inserir normas de proteção social e trabalhista (como uma Carta Social ou a ratificação de convenções da OIT), que eventualmente pudessem ser mobilizadas em favor de suas disputas no plano nacional. Além disso, a atuação sindical combinava elementos característicos de do repertório de confronto político - como atos públicos e marchas durante as Cúpulas de Presidentes - com a participação em instâncias institucionais, seguindo a agenda governamental, sobretudo, no SGT-11 e no FCES.

\section{Mercosul, ALCA e as mobilizações transnacionais contra o livre comércio}

Desde o início dos anos noventa, as pré-negociações para a criação de uma área de livre comércio hemisférica já colocavam uma dimensão adicional aos planos doméstico e o subregional. Como Mello (2000) argumenta, o próprio compromisso brasileiro com o Mercosul foi fortalecido a partir do objetivo estadunidense de avançar a liberalização comercial no continente. Em 1998, com o lançamento oficial das negociações da ALCA durante a III Cúpula das Américas, em Santiago, com conclusão prevista para 2005, a estrutura de oportunidades e ameaças políticas se tornou mais evidente para os diversos setores da sociedade brasileira.

A agenda de negociações incluía, entre outros temas, a remoção de restrições ao comércio de bens, acesso a mercados, agricultura, a harmonização de regras para serviços, investimentos, compras governamentais e propriedade intelectual, política de concorrência, subsídios, anti-dumping e direitos compensatórios. De 1994 a 1998, a estratégia da diplomacia brasileira foi protelar a ALCA o máximo possível, enfatizando a necessidade de resolver os contenciosos comerciais 
existentes, antes de avançar nas negociações. Contudo, a partir da Cúpula de Santiago, temendo o isolamento da região, o governo brasileiro passou a considerar o acordo como uma opção concreta (Vigevani et al., 2003)

Os desafios para a manutenção da coesão no Mercosul naquele momento se apresentaram, portanto, à sombra das negociações hemisféricas. Como já mencionado, desde sua origem, o Mercosul foi permeado de medidas defensivas por parte de seus sócios e flexibilizações frequentes. Apesar das pressões da ALCA, a partir de 1999, o bloco entrou em um período crítico marcado por sucessivas crises domésticas que afetaram fortemente a integração, como a desvalorização unilateral da moeda brasileira naquele mesmo ano. O Brasil assinou, unilateralmente, um acordo de preferências tarifárias com a Comunidade Andina de Nações, rompendo com a coesão no plano externo que se mantinha até então. Em 2000, tentou-se pela primeira vez, sem resultados, uma relançamento do Mercosul, com um programa para fortalecimento da união aduaneira. No ano seguinte, a crise argentina - cujo ápice foi a moratória em dezembro de 2001, que levou ao fim da convertibilidade peso-dolar e à troca de cinco Presidentes da República em dez dias - aumentou o panorama de incertezas. Em 2002, foram adotadas novas medidas para a retomada da parceira bilateral privilegiada entre Brasil e Argentina, com a assinatura do Protocolo de Olivos, que adicionou um mecanismo de solução de controvérsias à estrutura institucional do bloco, mas que não tem se mostrado capaz de resolver os conflitos entre os sócios. Segundo Mariano e Ramanzini (2012), a sucessão de conflitos configura uma crise institucional crônica e resulta do intergovernamentalismo extremo e da baixa densidade institucional do bloco, com instituições que não são capazes de canalizar os conflitos resultantes do aumento da interdependência. 
Neste período, ainda à sombra da ALCA e das debilidades do Mercosul, registra-se também um movimento de aproximação do Brasil com a América do Sul, com a Conferência de Brasília, que reuniu chefes de Estado e governos da América do Sul no ano 2000, sucedida por um segundo encontro no Equador em 2002. Embora esta reunião tenha dado origem a alguns projetos que serão retomados no futuro, como a Iniciativa para a Integração da Infraestrutura Regional Sul-Americana (IIRSA), neste momento a aproximação com a América do Sul não chegou a ser uma estratégia política (Vigevani et al., 2007: 3000). Ainda em 1999, Mercosul e União Europeia assinaram um acordo-quadro para as negociações de um acordo comercial, que só seriam lançadas oficialmente em 2004.

As negociações comerciais hemisféricas alteraram significativamente o panorama da mobilização social em torno do regionalismo e até hoje quase dez anos depois - funcionam como contraponto na articulação de um discurso pós-liberal por parte de setores da sociedade civil no Brasil e na região. As negociações da ALCA se mostravam pouco ou nada permeáveis às demandas dos movimentos sociais. Embora limitado, o governo brasileiro abriu um canal de diálogo com alguns setores sociais, inclusive sindicatos e ONGs, por meio da Seção Nacional de Coordenação dos Assuntos relativos à ALCA - Senalca). Contudo, a oposição frontal ao acordo fez com que a maior parte das organizações da sociedade civil decidisse não participar, como forma de não legitimar o processo. As ameaças eram percebidas no plano das negociações intergovernamentais, configurando um cenário propício para articulações transnacionais defensivas.

Entre os movimentos sociais, sindicais e ONGs, a oposição ao projeto da ALCA possibilitou possivelmente a maior mobilização continental já registrada. Segundo Von Büllow $(2010: 117,118)$, os esforços para a construção de uma coalizão transnacional contra o livre comércio trouxeram uma constelação de novas e velhas trajetórias para a 
transnacionalidade, tanto na dimensão ideacional, quanto organizativa. Coalizões transnacionais entre sindicatos já eram um forma de organização conhecida, como demonstra o caso do Mercosul e do Nafta, mas as coalizões multi-setoriais, reunindo sindicatos, ONGs e movimentos sociais em torno de uma luta comum contra o livre-comércio que articulava pautas variadas dessas várias organizações foi uma novidade que se difundiu a partir da experiência canadense contra o NAFTA. Segundo a autora, coalizões e redes sociais anteriores (no Nafta e no Mercosul) influenciaram a percepção das estruturas de ameaças e oportunidades políticas colocadas agora no plano hemisférico e foram por sua vez reorganizadas com a criação de novos laços e esforços para equilibrar relações de poder entre as diversas organizações. O objetivo da coalizão continental não era substituir organizações pré-existentes, mas criar um espaço de intersecção para coordenar a ação coletiva hemisférica.

No âmbito continental, a ação mais sustentada e coordenada se deu por meio da criação da Aliança Social Continental. Embora as articulações tenham começado na cúpula paralela à reunião ministerial da ALCA em Belo Horizonte, em 1997 - por iniciativa de organizações da sociedade civil do Brasil, Canadá, Chile, México e EUA, com apoio da ORIT - a consolidação da ASC ocorreu a partir 1999, culminando com o lançamento da Campanha Continental contra a ALCA no Fórum Social Mundial de 2002, em Porto Alegre. A ASC não uniu todo o conjunto de organizações que lutavam contra o livre comércio, mas agrupou uma boa parte dos atores mais relevantes. Dentre as organizações da sociedade civil brasileira mais atuantes na coalizão transnacional, Von Büllow aponta a centralidade da CUT, do MST e das ONGs Ibase e FASE (2010)

Segundo a autora, resultados prévios frustrantes no Nafta e no Mercosul teriam funcionado como um processo de aprendizado, particularmente no tocante à relação entre sindicatos e outras organizações da sociedade 
civil potencialmente aliadas. A experiência na CCSCS e no Mercosul ampliou e fortaleceu laços transnacionais da CUT. Um processo semelhante ocorreu no Nafta, alterando as estratégias da AFL-CIO, nos EUA, e do FAT, no México. A centralidade na rede continental ocupada por organizações sindicais seriam o resultado da decisão de buscar laços com outras organizações da sociedade civil, como sugere a iniciativa da CUT de contatar a FASE, antes da reunião ministerial da ALCA em Belo Horizonte, que formaria o embrião da Rede Brasileira para a Integração dos Povos (Rebrip) e funcionaria como o capítulo brasileiro da Aliança Social Continental. Vale ressaltar que embora as negociações da ALCA tenham capturado grande parte das atenções neste período, as considerações sobre o plano subregional com o Mercosul também estavam presentes. A primeira atividade que sinalizou publicamente a formação de uma coalizão multi-setorial brasileira (semelhantes às experiências dos ativistas canadenses e mexicanos) aconteceu de forma paralela à Cúpula de Presidentes do Mercosul, em dezembro de $1998^{35}$. A conferência internacional "Democracia, participação e a dimensão social nos acordos de integração - pela construção de uma Rede Brasileira para a Integração dos Povos" contou com ativistas de redes semelhantes de outros países e foi organizada pela CUT, FASE, Ibase e Conselho Regional de Economia do $\mathrm{RJ}^{36}$.

Mas, como lembra Von Büllow, nem todos os atores mobilizados contra o livre comércio estavam na Rebrip e na ASC. Apesar da Campanha contra a ALCA ter se originado no interior da Aliança, ela tornou-se maior e ganhou vida própria. Isso porque a Campanha permitiu que um número de organizações que não queriam ou não podiam integrar a ASC pudessem

\footnotetext{
35 Entrevista com Graciela Rodríguez (Rebrip/Instituto Equit).

${ }^{36}$ A conferência contou com ativistas da Rede Mexicana de Ação Frente ao Livre Comércio, da Rede do Quebec sobre Integração Contiental, da Rede Chile de Ação pela Integração dos Povos, da Aliança por um Comércio Responsável/EUA, do Alternatives/Canadá, além de um representante da ORIT e de Bernand Cassen, diretor geral do Le Monde Diplomatique, com papel bastante atuante no movimento altermundialista. Além das entidades organizadoras mencionadas, entre as várias organizações promotoras da atividade constam: $A B I, A b o n g$, Dieese, Contag, MST, FBOMS, UNE, Andes, PACS, ALOP.
} 
atuar de forma mais pontual da rede transnacional ${ }^{37}$. No Brasil, o capítulo nacional da campanha acolheu organizações ligadas à igreja, partidos políticos, parlamentares e indivíduos sem filiação. Mais uma vez, a existência de redes anteriores teve um papel importante: a maior decisão da Campanha foi a realização de um plebiscito popular continental sobre a $\mathrm{ALCA}^{38}$, que surgiu a partir da ideia de ativistas brasileiros que tinham organizado pouco tempo antes um plebiscito popular sobre o pagamento da dívida externa com a Campanha Jubileu Sul (Von Büllow, 2010)

Além das articulações prévias em torno do Nafta, do Mercosul e da Campanha Jubileu Sul, o movimento antiglobalização que emergiu no final da década de noventa também influenciou a mobilização continental. Segundo Berrón (2007), entre 1994 e 1997, uma série da fatores influenciaram o processo de mobilização posterior, como a insurgência zapatista em 1994 e as mobilizações contra o Acordo Multilateral de Investimentos, que foram combustíveis para a consolidação de um movimento antiglobalização no final dos anos noventa e cuja primeira grande reação coordenada aconteceu nos protestos contra a globalização e contra a OMC em Seattle, em 1999. Isso nos permitiria situar o movimento transnacional contra o livre comércio nas Américas dentro da emergência de um novo ciclo de protestos ${ }^{39}$. Para o autor, o poder de Seattle foi criar um novo tipo de ação que seria um paradigma do movimento antiglobalização e que teria um efeito importante sobre a resistência contra a ALCA que vinha se articulando desde 1997: después de Seattle, era imposible mantener aquel camino de "baja intensidad", incluso porque hacerlo hubiera significado quedar lejos de amplios

\footnotetext{
${ }^{37} \mathrm{Nem}$ todas as centrais sindicais integrantes da CCSCS participaram da Aliança Social Continental, seja por não rejeitarem totalmente a ALCA (como a Força Sindical no Brasil e a CGT argentina), seja por divergências dentro do movimento sindical com relação à ORIT .

38 A maior consulta popular ocorreu no Brasil, onde cerca de 10 milhões de pessoas votaram no plebiscito popular sobre a ALCA em setembro de 2002 (Von Büllow, 2010)

39 Segundo Della Porta, the emergence of a new cycle testifies to a rupture in the prevailing forms of collective action and organizational strategy as well as collective identities. In this sense, the perception of a sudden break reflects the challenges that cycles of protest pose to existing repertoires of collective action. During protest cycles, new organizational structures emerge with new styles of activism (Della Porta, 2007:2)
} 
sectores que parecian dispuestos a movilizarse y que lo harian de todas maneras. Nesta trajetória, a irrupção do Fórum Social Mundial estimulou a troca de experiências de luta e ajudou a facilitar o vínculo entre os atores contra o livre comércio no continente. Estas tendências convergiram em Québec, em abril de 2001, para a celebração da II Cúpula dos Povos, paralela à IV Cúpula das Américas. Segundo Berrón:

Québec fue el Seattle de los movimientos americanos, porque Seattle
fue protagonizado fundamentalmente por organizaciones del Norte,
mientras que Québec, estando incluso en el norte, fue una expresión de
la resistencia continental. Allí se juntaron el aluvión de jóvenes
desencadenado en Seattle con los grupos autonomistas de Québec y la
articulación continental en construcción. Québec dio visibilidad a todo
eso y contribuyó de forma contundente a la movilización que luego se
produciría, a la identificación del descontento con aquello que nadie
todavía conocía muy bien -el ALCA-y, finalmente, con la decisión final
de esta Alianza Social Continental de decirle "no al ALCA" y, en el
entusiasmo de la Segunda Cumbre de los Pueblos y de la presión para
una radicalización del mensaje por parte de muchos grupos y
movimientos del continente, lanzar una Campaña Continental Contra el
ALCA (Berron, 2007)

É difícil analisar separadamente as várias dimensões do ativismo transnacional que floresceram entre o final do anos noventa e meados de 2000. Nos planos subregional e hemisférico, as Cúpulas de Presidentes do Mercosul e as Cúpulas das Américas tornaram-se momentos fundamentais de articulação de redes, intercâmbio de informações e organização de cúpulas paralelas, que simbolizavam a falta de canais de participação das organizações da sociedade civil. Com exceção do movimento sindical no Mercosul, movimentos sociais e ONGs (que desempenhavam papel importante na produção de conhecimento especializado sobre as negociações e assessoria aos movimentos) não tinham espaços de diálogo nestas esferas. Inicialmente, a principal reivindicação do setor sindical nas negociações da ALCA era a existência de um canal para consulta formal aos sindicatos e outros atores da sociedade civil. Como afirma Berrón (2007), a explosão do movimento antiglobalização pressiona e radicaliza o movimento continental, fazendo com que a reivindicação de participação torne-se progressivamente 
rejeição ao projeto da ALCA. Temos portanto um cenário típico do transnacionalismo defensivo proposto por Sikkink (2005). Embora o movimento sindical por meio da CCSCS continue participando dos canais institucionais no Mercosul, neste período este processo é ofuscado pelas mobilizações sociais que articulam a luta contra a ALCA no plano continental.

Em 2003, com a reorientação política no Brasil e na Argentina e o início dos governos de Luis Inácio Lula da Silva e Nestor Kirchner, o cenário começava a dar sinais de mudança. Embora o governo brasileiro não tenha se retirado das negociações da ALCA, o Brasil passou a barganhar de forma mais dura, o que levou ao aumento de conflitos nas negociações ${ }^{40}$. Além da resistência organizada em amplos setores sociais em todo o continente e da mudança política no Brasil e na Argentina (que se somava à posição crítica da Venezuela desde 1998), as dificuldades de avanço nas negociações incluíam os impactos negativos do Nafta, a apreensão de alguns setores ligados às indústrias nacionais e resistências no interior dos EUA. Desse modo, na reunião ministerial de Miami, realizada em novembro de 2003, os países co-presidentes da ALCA (Brasil e EUA) reduziram as ambições iniciais e apresentaram um novo formato para as negociações, com a adoção de níveis variados de comprometimento ${ }^{41}$ para contemplar os graus diversos de assimetrias, o que ficou conhecido como ALCA light. Por fim, na $\vee$ Cúpula das Américas em Mar del Plata, as dificuldades já comentadas e a convergência política

40 Enquanto os Estados Unidos desejavam liberalizar temas como serviços, compras governamentais, investimentos e propriedade intelectual, a posição brasileira centrava-se no comércio agrícola e no acesso a mercados, evidenciando assim a incompatibilidade de interesses (Vigevani et al, 2007)

$41 \mathrm{Um}$ piso mínimo comum aos 34 países, com a inclusão de todos os temas da ALCA (acesso a mercados, agricultura, serviços, investimentos, compras governamentais, propriedade intellectual, etc.) e um segundo piso, no qual os países podem assumir níveis distintos de compromissos adicionais no âmbito da ALCA, por meio de acordos bilaterais ou plurilaterais 
entre Argentina, Brasil e Venezuela levaram ao adiamento sine die das negociações ${ }^{42}$.

42 Dos 34 países na mesa de negociação, a proposta foi rejeitada pelos quatro membros do Mercosul mais a Venezuela. 


\section{Capítulo III}

\section{O cenário da integração regional a partir de 2005}

Os anos 2000 registraram mudanças significativas na América do Sul e em sua inserção internacional, particularmente nas relações com os EUA e a China. Nos planos domésticos, forças políticas de vários espectros de esquerda chegaram aos governos nacionais no Brasil, Argentina, Uruguai, Bolívia, Equador, Paraguai, se somando a Chile e Venezuela. Apesar de diferenças significativas entre os vários processos, estas vitórias eleitorais levaram, em maior ou menor medida em cada país, a uma reorientação política, com graus variados de rejeição a políticas liberais da década anterior e à adoção de políticas públicas orientadas para a redução da pobreza e a inclusão social. No plano internacional, a década foi marcada pela consolidação da ascensão da China na Ásia e sua expansão crescente na África e na América Latina, por uma reorientação no foco da política externa estadunidense (que se volta para Ásia e Oriente Médio) e, em decorrência destes fatores, por uma ampliação da margem de manobra para a reorientação da política externa dos novos governos nos vários países sul-americanos. Contudo, estas reorientações não assumiram um sentido homogêneo com relação à integração regional, ao contrário, os diferentes modelos políticos e econômicos refletiram-se em um panorama diversificado de iniciativas de integração regional (Lima, 2013; Vigevani e Ramanzini, 2014). Neste sentido, destacam-se a reorientação do Mercosul para uma dimensão mais política e social; a criação da ALBA por iniciativa venezuelana; a persistência da orientação liberal nos tratados de livre comércio (TLCs) de Chile, Colômbia e Peru com os EUA e a Aliança do Pacífico ${ }^{43}$; e a sobreposição destas várias

\footnotetext{
${ }^{43}$ Após o adiamento das negociações hemisféricas, a estratégia dos EUA para a América Latina tem sido a negociação bilateral de Tratados de Livre Comércio com governos politicamente alinhados e/ou com pouca capacidade de barganha frente às investidas da agenda de "liberalização competitiva": com o Chile em 2004, com a América Central (o
} 
iniciativas com a entrada da Venezuela no Mercosul (e a adesão em curso da Bolívia) e, sobretudo, com a criação da União Sul-Americana de Nações (UNASUL), que tem se firmado como um modelo mais flexível e capaz de acomodar a heterogeneidade regional (Lima, 2013) sem, contudo, almejar a integração econômica e qualquer proposta de mercado comum (Vigevani e Ramanzini, 2014).

Apesar da persistência da visão comercial-liberal em alguns arranjos, a reorientação do Mercosul, a ALBA e a Unasul, ainda que com objetivos muito distintos, seriam expressões de uma revisão crítica das políticas econômicas liberais, o que tem sido denominado "regionalismo pós-liberal" (Lima, 2013, Vigevani e Ramanzini, 2014). Esta nova orientação no regionalismo seria caracterizada pela primazia da agenda política (incluindo aqui segurança e defesa), pelo papel do Estado na coordenação econômica (dimensões da integração produtiva e de infraestrutura) e preocupação com questões sociais, tanto no tratamento das assimetrias estruturais entre os países quanto na inclusão de setores marginalizados e na erradicação da pobreza na região (Lima, 2013; Vigevani e Ramanzini, 2014). A própria novidade da Unasul seria não

CAFTA-DR inclui: Costa Rica, El Salvador, Guatemala, Honduras, Nicarágua e República Dominicana) em 2006, Peru em 2009, Colômbia e Panamá, ambos em 2012. O Chile se destaca como um caso de implementação precoce de ajuste e liberalização econômica na região, ainda sob a ditadura de Pinochet, de modo que desde os anos noventa o país tem sido economicamente alinhado às posições estadunidenses. Além disso, $42 \%$ de suas exportações estão associadas a variedades de cobre (bruto, refinado e minério) e os maiores destinos das exportações são China (23\%) e EUA (12\%). Neste cenário, mesmo que politicamente tenha se aproximado da América do Sul pela Unasul, o Chile também vem perseguindo uma estratégia de acordos de livre comércio, que além do TLC com os EUA, se manifesta em diversos acordos com países asiáticos, dentre os quais a China, além da promoção da Aliança do Pacífico e da participação nas negociações da Parceria Transpacífica. O Peru exibe um perfil semelhante, alinhado econômica e politicamente aos EUA, com pauta de exportação dominada por recursos minerais (juntos ouro e minério cobre respondem por quase $40 \%$ do total de exportações) e, assim como o Chile, tem buscado inserção econômica internacional via uma série de TLCs, da Aliança do Pacífico e da Parceria Trans-Pacífica. No caso do CAFTA, embora os países não sejam homogêneos em seu alinhamento político aos EUA (pois inclui países governados por partidos de esquerda, como a Nicarágua e El Salvador), do ponto de vista econômico é um acordo com países de estruturas produtivas pouco diversificadas e bastante dependentes do mercado dos EUA. No caso da Colômbia, para além de convergências econômicas, é o alinhamento político-militar com os EUA que chama a atenção (com implicações comerciais para a indústria bélica), já que o país tem sido a principal porta de entrada dos EUA na região, via a injeção de bilhões de dólares pelo Plano Colômbia. 
pretender ser uma alternativa aos acordos comerciais, mas ir além destes com iniciativas de cooperação em outras áreas ${ }^{44}$, nas quais destacam-se a defesa $^{45}$ e de infraestrutura regional ${ }^{46}$.

Com o rápido desenvolvimento das agendas de infraestrutura e defesa, parte significativa das atenções se voltam para a Unasul, se comparadas a iniciativas "mais modestas" no Mercosul. Apesar dos impasses comerciais - que seguiram recorrentes -, das dificuldades em alavancar um projeto de integração produtiva e da fragilidade institucional, alguns temas avançaram, como o tratamento da assimetrias, a legislação

\begin{abstract}
${ }^{44}$ Com efeito, a estrutura institucional da Unasul privilegia este enfoque temático, com a organização de doze conselhos setoriais. A Unasul é formada pelo Conselho de Chefes de Estado e Governo, Conselho de Ministros das Relações Exteriores, Conselho de Delegados, 12 Conselhos Setoriais (Energia; Defesa; Saúde; Desenvolvimento social; Economia e Finanças; Eleitoral; Educação; Cultura; Ciência, tecnologia e inovação; Segurança cidadã, justiça e de combate ao crime organizado transnacional; Infraestrutura e planejamento) e uma Secretaria Geral.
\end{abstract}

45 Criado por iniciativa brasileira, o Conselho de Defesa Sul-Americano (CDS) é uma iniciativa pioneira, na medida em que reúne todos os países da América do Sul, num arranjo inteiramente independente do guarda-chuva estadunidense na região. O CDS resulta de uma combinação de fatores: a militarização da agenda de segurança dos EUA para a região (materializada em iniciativas como o Plano Colômbia e o reativação da IV Frota); o crescimento de tensões na região andina; como a experimentada por Equador e Colômbia no episódio de invasão do território equatoriano por parte do exército colombiano contra uma base das FARC; e a reorientação da política externa brasileira em busca de maior liderança regional (Battaglino, 2009:80). Aos fatores mencionados podemos adicionar ainda a expansão da indústria de defesa brasileira e seus interesses na região. Até o momento o CDS tem sido considerado uma experiência exitosa na medida em que a Unasul tem sido capaz de equacionar crises regionais (como a mencionada anteriormente entre Colômbia e Equador ou a ameaça separatista na Bolívia em 2008) e de desenvolver um pensamento regional nos temas de defesa (o que se materializou na recente inauguração da Escola SulAmericana de Defesa).

${ }^{46}$ A atenção ao tema da infraestrutura data do ano 2000, com a criação da IIRSA (Iniciativa de Integração da Infraestrutura Sul-Americana) na I Reunião de Presidentes da América do Sul. Na proposta inicial, o papel dos governos concentrava-se na dimensão técnica de estudos de viabilidade de projetos, com financiamento de bancos multilaterais como o BID, a CAF e o Fonplata. Em 2009, a área foi impulsionada politicamente com a criação do Cosiplan, com a função de conciliar os projetos de construção de rodovias, hidrovias, portos, gasodutos e infraestrutura para comunicações com uma perspectiva mais integrada de desenvolvimento local. Desse modo, o Cosiplan incorporou a IIRSA como fórum técnico, mas com o objetivo de incluir uma dimensão política de desenvolvimento integrado. O plano de ação estratégico para o decênio 2012-2022 conta com uma carteira de projetos com 531 iniciativas em torno de dez eixos, que buscam aumentar a conectividade física da América do Sul. A partir de 2005, o Brasil passou a ter um papel importante na execução de projetos do Cosiplan, via BNDES. Contudo, devido a limitações legais, que só permitem financiamentos do banco dentro das fronteiras brasileiras, o financiamento é feito a empresas brasileiras para a exportação de serviços de engenharia. Este passou a ser o principal meio de participação do Brasil nos projetos de infraestrutura sul-americanos, junto com o aumento das cotas brasileiras na CAF (Honorio, 2013) 
migratória e a adesão de novos membros. A seguir, descreve-se de forma resumida os principais temas no bloco na última década para, na sequencia, analisar a percepção e a atuação de organizações da sociedade civil no contexto de mudanças políticas no plano regional.

\section{Avanços e impasses no Mercosul}

A partir de 2003, a convergência política entre os Presidentes Lula e Kirchner renovou as esperanças entre os setores pró-integração no Mercosul, principalmente entre os defensores de um modelo que valorizasse as dimensões política e social. De fato, no âmbito dos discursos políticos dos Presidentes, o Mercosul ganhou espaço prioritário, com a defesa de políticas de complementariedade produtiva, de redução das assimetrias regionais e de políticas sociais. Boa parte desta nova agenda está presente no documento Objetivos 2004-2006, apresentado pelo Brasil na Cúpula de junho de 2003 e aprovado como plano de trabalho do bloco (CMC/26/03). Dentre as propostas do documento, cabe destacar: a criação de um parlamento regional e de um instituto social para coordenar políticas entre os Estados parte; o aprofundamento de acordos na área de imigração; o aperfeiçoamento das instituições; o tratamento da questão das assimetrias; e maior atenção aos temas da integração educacional, da cooperação em ciência e tecnologia e da integração física (CMC/26/03). Desde 2003, refletindo esta tentativa de diversificar a agenda da integração, novos órgãos foram criados, como a Comissão de Representantes Permanentes, o Parlamento Mercosul, o Fórum Consultivo de Municípios, Estados Federados, Províncias e Departamentos (que sucedeu a Reunião Especializada de Municípios e Intendências), o Instituto Social do Mercosul, o Instituto de Políticas Publicas de Direitos Humanos e as Reuniões Especializadas de Agricultura Familiar (REAF) e de Meio Ambiente.

Como será discutido adiante, o bloco tem se caracterizado por uma proliferação de órgãos sem poder decisório e, muitas vezes, sem recursos 
financeiros e humanos para seu funcionamento adequado. $\mathrm{O}$ objetivo aqui não será fazer um mapeamento exaustivo de todas as iniciativas e seus variados graus de êxito, mas resumir aquelas que têm sido destacadas pela literatura e por atores políticos e sociais. Neste sentido, abordaremos: o tratamento das assimetrias com a criação do FOCEM; a tentativa de impulsionar a integração produtiva; a questão migratória com o Acordo de Residência; a ampliação do bloco com a adesão da Venezuela; e a ampliação de mecanismos de diálogo e consulta à sociedade civil (este último será tratado separadamente adiante).

No campo econômico, a influência da visão pós-liberal se manifestou por dois conjuntos de ações relativas à integração produtiva e à redução das assimetrias entre os membros. Em linhas gerais, a perspectiva é de que a liberalização comercial sozinha não estimula a diversificação produtiva, nem tampouco a distribuição territorialmente equilibrada dos processos produtivos. Neste sentido, o fomento a políticas de integração produtiva teriam como objetivo não apenas promover a eficiência nas cadeias de valor regional, mas também favorecer objetivos de desenvolvimento social e territorial, como a participação de pequenas e médias empresas, sobretudo nos países de menor desenvolvimento relativo (CEPAL, 2014), associado a instrumentos para a redução das assimetrias.

Algumas inciativas recolocaram o tema da integração produtiva no Mercosul $^{47}$, com destaque para a criação do Programa de Integração Produtiva (CMC/52/07) e do Grupo de Integração Produtiva para coordenar e executar o programa ${ }^{48}$ (Alvarez et al., 2010). Para situar este

\footnotetext{
47 Vale lembrar que este tema está presente na agenda regional desde a aproximação bilateral entre Brasil e Argentina no final dos anos oitenta, conforme abordado no início do capítulo anterior.

$48 \mathrm{Um}$ documento da Agência Brasileira de Desenvolvimento Industrial (ABDI) relata os caminhos institucionais percorridos no bloco: Em julho de 2006 os presidentes dos países instruíram os Ministros das áreas vinculadas com a produção a definir as pautas que conformariam o "Plano de Desenvolvimento e Integração Produtiva Regional". Em cumprimento a este mandato, o Subgrupo de Trabalho (SGT) No 7 - Indústria levou para a consideração do Grupo Mercado Comum uma Proposta de Pautas para a Integração Produtiva do Mercosul. Em decisão de dezembro de 2007, o Conselho Mercado Comum
} 
tema, vale destacar que, na maioria dos países da América Latina, os produtos primários dominam a pauta de exportação extrarregional, ao passo que a própria região é o destino principal das exportações de bens de média e alta tecnologia ${ }^{49}$. No caso da Argentina, dados de 2010 apontam que cerca de $75 \%$ das exportações extrarregionais são de produtos primários, enquanto dentro do bloco $53 \%$ das exportações são de bens de tecnologia média. O cenário é semelhante para o Brasil: $72 \%$ das exportações extrarregionais são de bens primários, ao passo que quase $65 \%$ das exportações para o Mercosul são compostas de bens de média e alta tecnologia (CEPAL, 2011). Ainda segundo dados de 2010, o comércio de peças e partes, indicador usualmente considerado para avaliar a existência de cadeias regionais de valor, foi $15,2 \%$ do comércio total no Mercosul. Este valor é superior ao observado na América Latina como um todo, mas cerca de metade do percentual registrado na Ásia (CEPAL, 2014). Grande parte do comércio de bens de média e alta tecnologia, bem como do comércio de peças e componentes são puxados pelo comércio do setor automotivo, principalmente entre Brasil e Argentina.

Estes dados apontam um espaço considerável para a expansão de políticas de integração produtiva no bloco. Contudo, esta dimensão tem avançado de forma extremamente tímida, devido à falta de coordenação de políticas industriais e primazia adquirida pela exportações

(CMC) criou um Grupo Ad Hoc, vinculado ao Grupo Mercado Comum (GMC), responsável pela elaboração de um Programa de Integração Produtiva do Mercosul (Decisão CMC No 52/07)9. No âmbito das reuniões desse Grupo Ad Hoc, os Estados Partes negociaram os termos do referido Programa, cuja criação foi ratificada pelo CMC em julho de 2008. Para gerir a sua implementação foi criado o Grupo de Integração Produtiva do Mercosul (GIP), que opera no âmbito do GMC, cuja função é coordenar e executar o Programa, bem como todas as pro- postas e ações ligadas a essa temática (Decisão CMC No 12/08). (Alvarez et al., 2010)

49 Segundo dados da CEPAL, a participação do mercado intrarregional no total das exportações da América Latina (excluído o México) foi de $27 \%$ em 2013. Se excluídas as exportações de matérias-primas do cálculo (setor com elevada participação nas pautas de exportação e destinado majoritariamente a mercados extrarregionais), este valor chega a $57 \%$. Contudo, a maior parte deste comércio corresponde a bens finais, pois o intercâmbio de partes e componentes (indicador usado para estimar o grau de integração produtiva) chega a apenas $10 \%$ do comércio regional, revelando baixo grau de integração produtiva e avanços limitados na construção de cadeias de valor regionais (CEPAL, 2014) 
extrarregionais de matérias-primas a partir de 2003, com a alta dos preços no setor e a forte demanda chinesa. Se por um lado, este processo permitiu crescimento econômico e a implementação de políticas sociais e de redução da pobreza, por outro, aumentou a especialização nos setores primários que, acompanhada da valorização cambial, reduziu a competitividade dos setores industriais (CEPAL, 2014). Algumas iniciativas têm se desenvolvido no âmbito de pequenas e médias empresas, inclusive com apoio do FOCEM (como o projeto de adensamento e complementação automotiva no âmbito do Mercosul, executado pela $\mathrm{ABDI}$, voltado para pequenas e médias empresas produtoras de autopeças), mas com relação às grandes empresas líderes de cadeias produtivas os resultados tem sido modestos. Segundo Medeiros (2011), apesar do mérito das iniciativas recentes do Mercosul, razões históricas e estruturais dificultam o processo de integração produtiva na região, como as assimetrias e os distintos graus de diversificação e competitividade das estruturas produtivas nacionais. Apesar do alto grau de institucionalização da agenda produtiva, a CEPAL destaca a falta de clareza sobre os objetivos específicos, ações, prazos, orçamentos e responsáveis pelas iniciativas em curso, que dificultam uma avaliação do impacto das políticas de integração produtiva regional (CEPAL, 2014)

Por outro lado, o tratamento das assimetrias tem experimentado um grau de sucesso relativamente maior. Inspirado nos fundos de coesão da União Europeia, o Fundo para a Convergência Estrutural do Mercosul é um instrumento redistributivo para financiar programas e promover la convergencia estructural, desarrollar la competitividad y promover la cohesión social, en particular de las economías menores y regiones menos desarrolladas; apoyar el funcionamiento de la estructura institucional y el fortalecimiento del proceso de integración (Mercosul, CMC/DEC/45/04). Criado em 2004, o FOCEM iniciou seus projetos com um orçamento de US $\$ 100$ milhões, que no último ano chegou a US $\$ 1,133$ 
bilhões. Os principais contribuintes são o Brasil e a Argentina, responsáveis respectivamente por $70 \%$ e $27 \%$ dos recursos destinados ao Fundo. Do orçamento aprovado, 64,65\% são executados em 19 projetos no Paraguai e $24,17 \%$ em 12 projetos no Uruguai. O Fundo pode ser destinado a quatro tipos de projetos: convergência estrutural (contribuição para o desenvolvimento de economias menores, incluindo projetos de integração transfronteiriça, como a linha de transmissão de energia de Itaipu a Villa Heyes no Paraguai); desenvolvimento de competitividade (processos de reconversão produtiva, projetos de integração de cadeias produtivas e fortalecimento institucional de aspectos ligados à qualidade da produção, como padrões técnicos e certificações, como o projeto de complementação automotiva de pequenas e médias empresas mencionado anteriormente ${ }^{50}$ ); coesão social (projetos na área de saúde, redução da pobreza em áreas de fronteira); e fortalecimento da estrutura institucional do Mercosul. Cabe pontuar que a criação do FOCEM responde a uma pauta presente tanto no movimento sindical quanto no Partido dos Trabalhadores desde os anos noventa, como um instrumento capaz de fortalecer a integração e a dimensão de uma cidadania regional (Stuart, 2012).

A dimensão social começa a se fazer presente na agenda dos Presidentes com a Carta de Buenos Aires sobre compromisso social, de 2000 - que reconhecia não só a importância do crescimento econômico, mas também a responsabilidades dos Estados na formulação de políticas públicas para

\footnotetext{
50 En el ámbito del Grupo de Integración Productiva del MERCOSUR se aprobaron en 2010 dos Proyectos FOCEM sectoriales:

"Calificación de Proveedores de la Cadena Productiva de Petróleo y Gas", dirigido a fortalecer la cadena de aprovisionamiento de la industria regional de estos dos insumos energéticos, a partir de la integración de Pymes proveedoras de empresas "ancla", como Petrobras. Hay 100 beneficiarios y se están conformando los Comités Consultivos nacionales. Es decir, aún no arrancó.

Por otro lado, "Intensificación y Complementación Automotriz en el ámbito del MERCOSUR", dirigido a mejorar la competitividad de pymes proveedoras de autopartes. En esta primera etapa de capacitación, que involucra una inversión de 4M de dólares, participan 100 autopartistas: 30 empresas argentinas, 45 brasileñas, 10 paraguayas y 15 uruguayas. Organismo ejecutors: ABDI de Brasil. http://ciecex.com.ar/noticia2/integracion-productiva:la-cooperacion-empresarial-como-bien-publico-regional/
} 
redução da pobreza e das desigualdades sociais - e com a criação da Reunião de Ministros e Autoridades de Desenvolvimento Social (RMADS) no mesmo ano. A partir de 2003, a pauta da inclusão social e da redução da pobreza passa a ser enfatizada nos discursos oficiais. Institucionalmente as iniciativas de destaque são a criação do Instituto Social do Mercosul (ISM, órgão técnico de pesquisa), em funcionamento na cidade de Assunção e, em 2010, a aprovação do Plano Estratégico de Ação Social (PEAS - CMC/DEC/67/10), cujas diretrizes devem ser observadas pelos ministérios de desenvolvimento social na formulação de políticas públicas nacionais.

Destaca-se também na última década a entrada em vigor do Acordo de Livre Trânsito e Residência para Nacionais dos Estados Partes do MERCOSUL, aprovado em 2002 e vigente a partir de 2009 (CMC/28/02). O Acordo assegura a todos os imigrantes provenientes dos países signatários ${ }^{51}$ a igualdade de direitos (excetuado no Brasil o direito de voto) e serviu como marco para a elaboração de leis migratórias na Argentina e no Uruguai. Apesar de alguns entraves ${ }^{52}$, o Acordo é considerado um avanço importante por especialistas e ativistas ${ }^{53}$.

$\mathrm{Na}$ dimensão política, a suspensão do Paraguai e a inclusão da Venezuela como membro pleno do bloco figuram entre as questões de maior destaque no período. Entre a assinatura do Protocolo de Adesão

\footnotetext{
51 Argentina, Brasil, Paraguai, Uruguai e os Estados associados Bolívia, Chile, Peru, Colômbia e Equador.

52 Embora a documentação requerida seja relativamente simples (certificado de antecedentes criminais, comprovação de meios de subsistência e o pagamento de taxas), ainda existem algumas dificuldades para a obtenção de documentos relativas ao alto grau de trabalho informal e ao pagamento de taxas (CDHIC) e ainda as limitações para o reconhecimento de diplomas (Baraldi)

53 Neste caso, o avanço no Mercosul é limitado pela legislação migratória no Brasil, que ainda é regido pelo estatuto do estrangeiro aprovado no regime militar, considerado por especialistas e militantes do tema uma lei discriminatória, xenófoba, que trata o imigrante como um perigo à segurança nacional. Estas considerações estão feitas por exemplo na tese de Baraldi (2014), em artigo de Reis e Ventura

(http://www.cartacapital.com.br/sociedade/divida-historica-uma-lei-de-migracoes-para-obrasil-9419.html); de Paulo Illes (http://www.cdhic.org.br/?p=119) e foram mencionadas na entrevista com Tania Rocio, coordenadora executiva do Centro de Direitos Humanos e Cidadania do Imigrante.
} 
em 2006 e a oficialização da entrada da Venezuela em 2012, tivemos um longo período marcado pelo lento processo de aprovação no Congresso brasileiro e, sobretudo, pela oposição do Congresso paraguaio. Esta controvérsia atingiu outro patamar quando a adesão foi finalmente formalizada durante a suspensão do Paraguai devido à ruptura da ordem democrática em $2012^{54}$, portanto sem a ratificação do acordo de adesão naquele país, o que só ocorreria no final de 2013. Alguns apontam que a adesão da Venezuela é problemática porque o país não estaria alinhado com a maioria dos regulamentos regionais (Malamud e Rodriguez, 2013), mas a entrada foi comemorada e bem vista pela maioria das organizações da sociedade civil que atuam no bloco, na medida em que contribuiria para romper a divisão entre Mercosul e ALBA, como veremos adiante.

Ainda na dimensão política, mas desta vez como maior exemplo de impasse, tivemos um longo conflito diplomático sobre a implementação de duas plantas de indústria de celulose às margens do rio Uruguai, em território uruguaio, que provocou conflito sobre a política de atração de investimentos, forte reação de movimentos ambientalistas na província de Entre Ríos/Argentina e se arrastou até a Corte Internacional de Justiça em Haia, colocando em evidência a fragilidade da institucionalidade do Mercosul, que não foi capaz resolver o impasse (Ventura e Miola, 2009).

\section{A criação de novos mecanismos participativos no Mercosul}

Com a chegada ao governos do Brasil, Argentina e Uruguai (e brevemente no Paraguai entre 2009 e 2012) de quadros oriundos do sindicalismo e dos movimentos sociais, muitos dos quais haviam atuado diretamente na articulação da CCSCS, participado das discussões no âmbito do SGT11 e do FCES e contribuído na construção da ASC e da Campanha contra a ALCA, começaram a surgir discussões no âmbito do governo sobre

\footnotetext{
54 Um bom exemplo desta controvérsia pode ser lido nos artigos de Celso Lafer e Marco Aurelio Garcia sobre o tema, publicados na revista Política Externa Vol. $21 n^{\circ} 3$ Jan/Fev/Mar 2013
} 
possíveis ações para revitalizar a integração regional e incluir novos setores da sociedade civil. Estas iniciativas partiram em grande medida da Secretaria Geral (SG) da Presidência da República, na época chefiada pelo Ministro Luiz Soares Dulci, sobretudo da assessoria internacional. Estas ações se desenvolveram tanto no plano regional, com a organização de Cúpulas Sociais do Mercosul, quanto nacional, com a criação de canais de diálogo com a organizações da sociedade civil no Brasil, na Argentina e no Uruguai, sobre temas relacionados ao bloco. No Brasil, a atividades começaram com reuniões em diversas capitais dos estados e, em 2008, atingiram maior institucionalização com o Programa Mercosul Social e Participativo, pensado originalmente como um conselho, semelhante aos existentes em áreas diversas de políticas públicas.

Durante a presidência pro tempore brasileira no segundo semestre de 2004, o governo brasileiro, por iniciativa da assessoria especial do Ministro da Secretaria Geral da Presidência, deu início a uma iniciativa para "popularizar" o Mercosul, por meio da promoção de atividades sobre a integração regional em diversas capitais brasileiras ${ }^{55}$. Estes eventos, chamados "Encontros com o Mercosul", foram convocados pela SG, pelo Ministério das Relações Exteriores e pelo Fórum Consultivo Econômico e Social do Mercosul, em parceria com governos estaduais e entidades representativas de empresários e de sindicatos em vários Estados da federação, e com a presença de organizações da sociedade civil diversas, como ONGs e movimentos sociais. Estes "Encontros" foram realizados em várias capitais, como Recife/PE, Salvador/BA, São Luiz/MA, com ênfase particular nas regiões norte e nordeste, de forma a sensibilizar um maior número de lideranças para o tema da integração. As entidades mais atuantes nestas convocações foram a CUT e a CGT, por parte das

55 Entrevista com Giorgio Romano Schutte, assessor especial do Ministro da SG-PR de 2004 a 2006 
centrais, a CNC, a CNT e, em menor medida, a CNI, por parte dos empresários, além de autoridades locais ${ }^{56}$.

No segundo semestre de 2005, durante a PPT uruguaia e no primeiro ano de mandato do Presidente Tabaré Vázquez, também a partir da presença de quadros oriundos do sindicalismo (especialmente da CCSCS) e da Frente Ampla no governo, o Uruguai revitalizou o Centro de Formação para a Integração Regional (CEFIR) e, neste âmbito, lançou um programa semelhante ao brasileiro, chamado de Somos Mercosur. com o objetivo de incluir outros setores da sociedade civil no bloco. No âmbito do Somos Mercosur foi se consolidando a ideia de reunir diversas organizações da sociedade civil do campo progressista para pensar politicamente a revitalização do Mercosul em novas bases ${ }^{57}$. No primeiro semestre de 2006, durante a PPT argentina, foi organizado em parceria com o Somos Mercosur e com a CCSCS o Encontro por um Mercosul Social e Produtivo, em Córdoba, paralelamente à Cúpula dos Presidentes. Estas ações foram precursoras do que viriam a ser as Cúpulas Sociais do Mercosul, organizada pela primeira vez com este título, durante a PPT brasileira no segundo semestre de 2006. Em todo este processo, as relações prévias na CCSCS, entre os sindicatos do Cone Sul e mesmo as fortes relações entre os partidos de esquerda e centro-esquerda anteriores às vitórias eleitorais (tanto institucionais, quanto pessoais com um trânsito significativo de militantes exilados durante os regimes militares) mostram um cenário de articulações políticas fora da esfera diplomática que se transfere para os governos a partir de 2003, retroalimentando as iniciativas em cada país.

Em 2006, o novo assessor especial da SG propôs uma nova fórmula para o diálogo com as organizações da sociedade civil no âmbito regional, de modo a contemplar não apenas os setores ligados ao mundo produtivo -

\footnotetext{
56 ibidem

57 Entrevistas com Giorgio Romano Schutte, assessor especial da SG-PT de 2004 a 2006, e com José Renato Vieira Martins, que ocupou o mesmo cargo entre 2006 a 2010.
} 
que já ocorria no FCES - mas também ONGs e os movimentos sociais diversos que haviam despertado para os temas internacionais e de política externa a partir dos Fóruns Sociais Mundiais e da experiência da Aliança Social Continenta ${ }^{58}$. Desde o início, o formato das Cúpulas Sociais contou com uma série de resistências dentro do governo e também na sociedade civil, segundo informa o então responsável pelo modelo das Cúpulas, Renato Martins. Uma das questões controversas dizia respeito à necessidade de garantir a autonomia das organizações da sociedade civil e, neste sentido, havia dúvidas sobre a adequação de que o governo tomasse a iniciativa de convocar e organizar estas reuniões paralelas ${ }^{59}$. Como veremos adiante, este tema será ainda mais presente nas considerações da sociedade civil. Também havia insatisfações por parte do movimento sindical, que durante os anos noventa havia investido na construção do FCES. Um segundo problema era decidir quem era a sociedade civil e a controversa presença de partidos políticos, excluídos do processo ${ }^{60}$. Por fim, um terceiro grupo de resistências se manifestava em áreas do Estado, particularmente no Itamaraty. Neste último caso, os dois assessores especiais da SG que ocuparam o cargo entre 2004 e 2010 relatam que apesar das resistências iniciais, progressivamente criouse uma relação de confiança com Itamaraty, especialmente com os embaixadores e diplomatas da divisão Mercosul que acompanharam o processo.

Vencidas as resistências, em dezembro de 2006 foi organizada a I Cúpula Social do Mercosul. Inicialmente, estas cúpulas sociais eram organizadas pela Presidência Pro Tempore sem um caráter oficial, mas

\footnotetext{
58 Entrevista com José Renato Vieira Martins, assessor especial do Ministro da Secretaria Geral da Presidência de 2006 a 2010.

59 Preocupação presente não apenas nas organizações da sociedade civil, mas também expressada pelo Ministro Luiz Dulci, segundo Martins.

60 Esta controvérsia se deu principalmente com a SRI-PT, que desde o início dos anos noventa vinha elaborando reflexões e se pronunciando sobre o tema da integração regional (ver por exemplo Carta de Curitiba, fruto de um seminário na cidade em 1993). Por outro lado, a dificuldade da SG-Presidência da República era evitar que estes novos espaços se tornassem um fórum de partidos, já que não seria possível excluir todos os outros.
} 
progressivamente, foram se consolidando: na $\mathrm{XL}$ reunião do $\mathrm{CMC}$ em 2010, durante a Presidência Pro Tempore brasileira, foi instituída a Unidade de Apoio à Participação Social (UPS), para atuar como canal institucional de diálogo com a sociedade civil, apoiar a organização das cúpulas sociais, financiar a participação social em eventos e atividades do bloco e manter um registro das organizações e movimentos sociais nos Estados Partes (CMC/65/2010). Em 2012, novamente durante a PPT brasileira, as Cúpulas Sociais foram institucionalizadas ${ }^{61}$ (CMC/56/12), com a previsão de um fundo de apoio à participação, que ainda não foi implementado.

As Cúpulas estão associadas domesticamente a pontos focais, que devem realizar sessões de trabalho com as respectivas sociedades civis no intervalo as Cúpulas semestrais do bloco. No Brasil o ponto focal é o Programa Mercosul Social e Participativo ${ }^{62}$ (PMSP), criado oficialmente em 2008 e também coordenado pela Secretaria Geral da Presidência da República e pelo Ministério das Relações Exteriores, com o objetivo de reunir representantes dos vários Ministérios envolvidos e organizações da sociedade civil para debater temas relativos à integração e encaminhar propostas ao CMC e ao GMC.

Inicialmente o PMSP seria o Conselho Brasileiro do Mercosul Social e Participativo, baseado na experiência dos vários conselhos gestores existentes no âmbito do Estado brasileiro ${ }^{63}$. Mas como já mencionado no caso da cúpula social, a criação de um Conselho composto por organizações da sociedade civil na área de política externa encontrou

\footnotetext{
${ }^{61}$ Art. 1o. a Cúpula Social do Mercosul deverá ser realizada semestralmente e sua organização será responsabilidade da Presidência Pro Tempore, em coordenação com os demais Estados Partes e o Coordenador da Unidade de Apoio à Participação Social. Para tanto, cada Estado Parte deverá designar um ponto focal titular e um alterno. Art. 20. Os resultados da Cúpula Social serão apresentados na primeira reunião ordinária do Grupo Mercado Comum que se realize depois da Cúpula (CMC/56/12).

62 A Argentina e o Uruguai contam com pontos focais semelhantes no âmbito das chancelarias (o já mencionado Somos Mercosur no caso uruguaio e o Conselho Consultivo da Sociedade Civil na chancelaria argentina).

63 Entrevista com José Renato Vieira Martins
} 
ainda mais resistências no MRE e na própria Presidência da República. Um fato curioso ilustra o caso: o decreto presidencial que cria o PMSP foi assinado em 06 de outubro de 2008. Quatro dias antes, notícia veiculada na página da Secretaria Geral da Presidência da República afirmava:

O presidente Luiz Inácio Lula da Silva assina nesta segunda-feira (6), às 11h30, decreto que institui o Conselho Brasileiro do Mercosul Social e Participativo em solenidade a ser realizada no Palácio do Planalto. Na cerimônia também será divulgada a relação de atividades do Programa Mercosul Social e Participativo. Ambas as iniciativas são coordenadas pela Secretaria-Geral da Presidência da República e pelo Ministério das Relações Exteriores e têm o objetivo de complementar a integração regional do Mercosul com ações que vão além da esfera econômica e comercial.

O Conselho Brasileiro do Mercosul Social e Participativo se reunirá quatro vezes ao ano - sempre antecedendo as reuniões do Grupo Mercado Comum - para divulgar as políticas e iniciativas do governo relacionadas ao Mercosul, fomentar discussões sobre temas diversos da integração e encaminhar sugestões emanadas da sociedade civil. (...) 0 Programa Mercosul Social e Participativo consiste na realização de um conjunto de atividades durante a Presidência Pro Tempore brasileira com o propósito de aproximar o Mercosul do cidadão comum ${ }^{64}$

O Decreto assinado quatro dias depois não faz qualquer menção à palavra Conselho e situa suas atribuições no Programa Mercosul Social e Participativo. Apesar do revés, O PMSP conseguiu assegurar um orçamento para sua implementação e, ao contrário da seção nacional do FCES, que nunca teve orçamento próprio, as organizações que participam do PMSP são financiadas. As reuniões são realizadas em Brasília, no Palácio do Planalto, ou no escritório da Presidência da República em São Paulo (atualmente fechado). Embora o objetivo inicial fosse criar uma instância semelhante aos conselhos gestores, o formato concretizado é menos ambicioso. Ainda não há uma portaria que regulamente critérios claros de participação e funcionamento, de modo que ainda também não há procedimentos claros para determinar quem participa pela sociedade civil no PMSP e também não há regras específicas para dar seguimento ao que é debatido nas reuniões. Ainda que o Conselho não tenha sido criado nos moldes desejados pela assessoria internacional da SG, a

${ }^{64}$ http://www.secretariageral.gov.br/noticias/2008/10/not_02102008 
percepção era de que ainda assim valeria a pena institucionalizar o formato possível, na expectativa de que com o tempo fosse possível delinear atribuições e critérios mais claros ${ }^{65}$.

No caso da Cúpula Social, a Presidência Pro Tempore que a organiza financia a participação de algumas entidades de cada país. No Brasil, a escolha das entidades que receberão financiamento ocorre por deliberação das próprias organizações da sociedade civil que participam do PMSP. Este dado foi confirmado por meio da observação participante em algumas reuniões do PMSP e também foi mencionado durante as entrevistas.

Tanto as Cúpulas Sociais quanto as reuniões do PMSP contam com a presença de diversas organizações da sociedade civil, como centrais sindicais, ONGs e movimentos sociais. Ainda não há um registro sistemático das organizações que têm participado das diversas edições das Cúpulas Sociais e das reuniões do PMSP, inclusive está em andamento um edital da Unidade de Apoio à Participação Social para o desenvolvimento de projetos com o intuito de justamente sistematizar este processo. Uma lista das organizações brasileiras que têm acompanhado as reuniões foi construída a partir de listas divulgadas na internet pela própria SG e por algumas organizações participantes (Anexo 2).

Além destes espaços consultivos multi-setoriais, houve também uma ampliação das reuniões especializadas - subordinadas ao GMC - e de reuniões de ministros, ligadas ao CMC. Constam no organograma do Mercosul 19 reuniões de Ministros e/ou Altas Autoridades e 17 reuniões especializadas, conforme especificado no anexo 3. Muitas destas reuniões abrem espaço para a participação de organizações da sociedade civil, em geral com o caráter de observadores. A grande maioria não prevê critérios

\footnotetext{
65 Entrevista com José Renato Vieira Martins, assessor especial do Ministro da Secretaria Geral da Presidência de 2006 a 2010.
} 
claros para esta participação em seus regimentos e a abertura para o acompanhamento de entidades da sociedade civil fica a cargo de cada ministério. A principal exceção é a Reunião Especializada de Agricultura Familiar que, criada em 2004, prevê em regimento a composição paritária entre representantes dos governos e das sociedades civis ligadas ao campo. Uma rápida descrição da participação de organizações da sociedade civil em três reuniões selecionadas mostra a falta de critérios unificados: A Reunião Especializada de Agricultura Familiar (REAF), a Reunião Especializada da Mulher (REM) e a Reunião e Altas Autoridades em Direitos Humanos (RAADH).

A concretização da REAF ocorreu de forma simultânea à própria estruturação de um ministério voltado para a agricultura familiar e reforma agrária no Executivo brasileiro. A demanda pela inclusão da agricultura familiar na pauta do Mercosul já existia, como descrito anteriormente com a criação da Coprofam em 1994. Mas a efetivação de uma instância específica resultou não apenas das reivindicações dos movimentos, mas também do objetivo do próprio Ministério do Desenvolvimento Agrário de criar espaço de atuação dentro governo federal ${ }^{66}$. Ao longo de mais de dez anos de funcionamento, a REAF tem sido considerada uma experiência exitosa (Carvalho, 2011) na medida em que conseguiu incidir sobre as políticas dos governos nacionais ao regionalizar o conceito de agricultura familiar, entendido como como um setor com necessidades de políticas públicas específicas para além do agronegócio.

\footnotetext{
66 Segundo Carvalho, em 2003, com a posse de novos governos na Argentina e, em especial, no Brasil, teria havido uma convergência de interesses que permitiu a construção da REAF. No Brasil, o Ministério do Desenvolvimento Agrário via a articulação regional dos interesses da agricultura familiar como uma ação necessária para garantir maior representação destas demandas nas negociações comerciais das quais o Brasil então participava, como a ALCA e a OMC, inclusive como forma de equilibrar internamente os interesses do agronegócio e a atuação do Ministério da Agricultura. De acordo com a própria autora: A criação de um espaço para discutir agricultura familiar no Mercosul se concretiza quando às demandas de um grupo de organizações do campo que buscava incidência sobre o bloco, somam-se as vontades, interesses e necessidade dos ministérios brasileiros, sobretudo dos Ministérios das Relações Exteriores e do Desenvolvimento Agrário (2011:71,72).
} 
No mesmo ano de criação da REAF, foi instituída também a RAADH, como um espaço de coordenação intergovernamental para políticas públicas na área de Direitos Humanos. Em 2009, por recomendação da RAADH foi criado o Instituto de Políticas Públicas em Direitos Humanos, que tem por funções a cooperação técnica, pesquisa, capacitação e apoio na coordenação de políticas regionais na área $(C M C / 14 / 09)$. Segundo relatório da ONG Instituto de Defesa dos Direitos Humanos - organização que acompanha o tema no bloco - a RAADH ainda não possui um Regulamento Interno aprovado para guiar seu funcionamento e, como consequência, a participação social também não é institucionalizada nesse espaço. Segundo o mesmo relatório, essa participação tem ficado a critério de cada Estado que detém a Presidência Pro Tempore, mas há uma proposta de Regulamento Interno da RAADH que, dentre outros pontos, visa regulamentar a participação social (IDDH, 2012).

A Reunião Especializada da Mulher também foi ampliada neste período. Criada em 1998, inicialmente previa em regimento uma função específica de assessoria ao Fórum de Mulheres do Mercosul, uma ONG fundada por empresárias e representantes de partidos, criada a partir de um grupo ligado ao Ex-Presidente Menem na Argentina. Com a ampliação da participação de outras organizações ligadas aos sindicatos e ao movimento feminista, foi possível retirar o caráter privilegiado do Fórum de Mulheres do Mercosul e ampliar o fluxo de informações para outros setores na sociedade $\mathrm{civil}^{67}$.

A falta de critérios claros se repete em praticamente todas as reuniões, com honrosa exceção da REAF. Como a abertura para a participação de organizações da sociedade civil depende dos coordenadores de cada reunião, e às vezes até mesmo dos coordenadores de cada comitê ou grupo de trabalho dentro de cada reunião, (que mudam também em cada Presidência Pro Tempore), o mapa completo envolveria todos os comitês

${ }^{67}$ Entrevista com Graciela Rodríguez, Instituto Equit/Rebrip. 
e grupos de 19 reuniões de ministros, 17 especializadas, além dos Subgrupos e Grupos ad hoc. O trabalho é dificultado pela falta de registro em ata da participação destas organizações, bem como a dificuldade de acesso às atas específicas de cada comitê.

Com o intuito de sistematizar o que foi exposto até o momento, o Mercosul dispõe atualmente de uma série de canais participativos, formais e informais:

- O FCES e suas seções nacionais - centrado nas discussões do universo produtivo, com regimento e critérios claros de participação, sem financiamento das entidades.

- Uma série de mecanismos informais no âmbito das Reuniões de Ministros, Reuniões Especializadas e Subgrupos de Trabalho temáticos, sem critérios claros, com decisões a cargo dos coordenadores rotativos de cada instância ou a cargo dos ministérios de cada país.

- Instâncias de participação no âmbito dos governos nacionais (PMSP no Brasil) - ainda sem uma portaria que regulamente critérios claros de participação, com presença bastante diversificada de sindicatos, ONGs e movimentos sociais, com financiamento para participação.

- Cúpulas Sociais do Mercosul - sem critérios claros de participação, tem caráter ambíguo na medida em que tem origem no modelo de cúpulas dos povos, mas passam a ser facilitadas pelos governos. Reúnem um leque diverso de organizações (em geral o mesmo perfil do PMSP acima descrito). Foram progressivamente institucionalizadas. Atualmente há financiamento de um número limitado de organizações (no Brasil, as próprias organizações da sociedade civil decidem quem será financiado) 


\section{Percepções e estratégias das organizações da sociedade civil}

As reorientações que se processavam no interior do Mercosul, nas negociações da ALCA e na política externa brasileira de forma geral exigiam das organizações da sociedade civil uma nova estratégia. Ainda no período compreendido entre 2003 e 2005, o governo já sinalizava uma abertura distinta à sociedade civil, com a inclusão de representantes de sindicatos, ONGs e movimentos sociais que se mobilizavam contra a ALCA na delegação oficial brasileira nas negociações ${ }^{68}$. Como as negociações eram secretas, esta abertura foi significativa não apenas para as organizações brasileiras, mas para a articulação continental, na medida em que os ativistas brasileiros divulgavam os detalhes das negociações em suas redes e, assim ativavam, segundo Von Büllow a operação de um mecanismo bumerangue inverso, provendo informações às organizações da sociedade civil que dispunham de canais restritos com seus governos nacionais, como os EUA durante o governo Bush (2010:184).

Como descrito anteriormente, no Mercosul, a abertura de novos canais de diálogo com a sociedade civil ocorreu em dois planos: as Cúpulas Sociais em âmbito regional e novos espaços de interlocução nacionais, por iniciativas particulares de cada país. As respostas por parte das organizações da sociedade civil não foram unânimes, mas houve um aumento no número e na diversidade das organizações que passaram a participar de canais de consulta no Mercosul.

As reações assumiram duas formas: por um lado, uma tentativa de seguir com a articulação independente do período prévio, organizada sobretudo em torno das Cúpulas dos Povos do Sul, com a possibilidade de seguir uma agenda própria, mas com o desafio de manter de "apoio crítico" às

68 Segundo Midley e Silva (2008) neste período a delegação oficial brasileira nas negociações chegou a ter mais de 30 representantes, o que incomodou os negociadores de outros países. A autora comenta que os EUA tentaram limitar o número de delegados a quatro por país, o que foi rechaçado pelo governo brasileiro. 
propostas de integração dos novos governos; e, por outro lado, a participação nos novos canais de diálogo propostos pelos governos, com o desafio de manter a autonomia dos movimentos nesta interlocução.

\section{A organização autônoma na Cúpula dos Povos do Sul}

A organização de cúpulas paralelas, com a presença de movimentos sociais, sindicais e variada gama de ONGs, simultâneas às cúpulas oficiais de Presidentes ou altas autoridades de Estado, se firmou como um dos principais repertórios de ação coletiva transnacional nos anos noventa (Pianta, 2001). Esta forma de mobilização ocorreu nas Conferências mundiais da ONU (Clark et al., 1998:22), nos encontros de instituições econômicas internacionais como o G8 e o FMI, nas negociações da ALCA (Berrón, 2007) e na própria concepção do Fórum Social Mundial que, embora tenha adquirido vida própria, também teve em sua origem o contraponto ao Fórum Econômico de Davos. Segundo Pianta, este repertório tornou-se uma forma de questionar a legitimidade das cúpulas oficiais, confrontar as autoridades, dar visibilidade às organizações da sociedade civil, resistir às políticas neoliberais e propor alternativas (2001: 171). Ainda de acordo com o autor, as cúpulas paralelas, que podem ou não ter contatos formais com as cúpulas oficiais, são eventos definidos pela organização de grupos da sociedade civil, de forma independente de Estados e empresas; pela simultaneidade com as cúpulas oficiais; pela discussão dos mesmos temas dos eventos oficiais, mas a partir de uma perspectiva crítica; e pelo uso de meios de informação pública, mobilização política e protestos (ibidem).

Como já foi mencionado anteriormente, as Cúpulas dos Povos das Américas tornaram-se o principal ponto de encontro das redes e coalizões transnacionais contra a ALCA. De acordo com outros trabalhos sobre o tema (Von Bullow, 2010; Berron, 2007) e também com as entrevistas realizadas para esta pesquisa, a III Cúpula dos Povos das Américas, 
paralela à oficial $\vee$ Cúpula das Américas, realizada em Mar del Plata em 2005, palco do final do projeto da ALCA, já apresentava o dilema da autonomia frente a "governos amigos", na medida em que pela primeira vez houve a participação direta de partidos políticos e líderes de governo, causando forte disputa no interior dos movimentos ${ }^{69}$ com relação à organização autônoma da atividade, que por fim foi possível:

Quando a gente começa a ter que lidar mais com uma agenda "positiva" a coisa começa a se complicar, eu me lembro que em 2005 em Mar del Plata, a gente comentava: "gente, agora ao mesmo tempo a gente comemora uma vitória, mas a gente sabe que vai entrar num período dificílimo pros movimento sociais na região ${ }^{70}$

Frente aos novos dilemas do cenário regional a partir de 2005, há inicialmente uma tentativa dos movimentos integrantes da Aliança Social Continental de manter a articulação autônoma das Cúpulas dos Povos, dessa vez centradas no Mercosul. Apesar de longo, o trecho citado a seguir, a partir da entrevista com a representante do Instituto Equit, integrante da Rebrip, é bastante esclarecedor ao mostrar os dilemas da organização autônoma e da relação com os governos:

(...) em julho de 2006, em Córdoba na Argentina se faz a primeira Cúpula dos Povos do Mercosul, que tinha também esse caráter autônomo. O movimento sindical já dialogava [com as instâncias oficiais do Mercosul] via o FCES, mas nesse momento os governos nos ofereceram algum tipo de diálogo, então houve um dialogo da cúpula dos povos com a cúpula oficial. (...) Daí em diante, de seis em seis meses nós organizamos até 2010 a Cúpula dos Povos do Mercosul. Foi um esforço enorme porque aí sim era uma tentativa a partir dos movimentos sociais de manter viva esta forma autônoma de organização. (...) Acontece que também surge no Uruguai a proposta de criação de um espaço facilitado pelos governos para organizar uma cúpula da sociedade civil. Então também no final de 2006 há pela primeira vez uma coisa que foi chamada no Uruguai de Somos Mercosur e depois foi chamada de Cúpula Social do Mercosul. (...) Os anos seguintes foram um pouco dificeis porque tivemos este duplo formato: a cúpula social e, ao mesmo tempo, nós já tínhamos começado a construção da cúpula dos povos, queríamos manter esta forma

${ }^{69}$ Entrevista com Graciela Rodríguez, Instituto Equit/Rebrip

70 Entrevista com Fátima Mello, FASE/Rebrip 
autônoma da organização. As cúpulas dos povos sempre dialogaram com as cúpulas sociais, nunca foram cúpulas anti-Mercosul, (...) nunca foram cúpulas dos povos da mesma forma que eram pra ALCA, neste caso eram cúpulas que queriam dialogar com o processo Mercosul, queriam ajudar a construir propostas. Então se criou esse duplo caminho das cúpulas sociais, que foram tomando um caráter um pouco mais ligado aos governos, porque eram os governos que convidavam para a cúpula social. (...) Nós continuamos tendo esta dificuldade de ser chamados pelos governos, isso tem dado bastante conflito no interior da própria cúpula social, porque enquanto tínhamos a cúpula dos povos e as cúpulas sociais, as entidades que queriam só participavam da cúpula social e também tínhamos a oportunidade de fazer nosso próprio debate com total autonomia e dialogar com essa cúpula social, seja com o governo, seja com os participantes da sociedade civil.

As Cúpulas dos Povos do Mercosul foram organizadas de 2006 a 2010, a partir dos capítulos nacionais da Aliança Social Continental. Antes do processo de declínio e perda de vitalidade, praticamente todas as organizações que participaram do movimento contra a ALCA estiveram envolvidas neste processo. Na Argentina: CTA, Jubileu Sul, Attac e Mocase (esta última filiada à Vía Campesina). No Brasil o processo foi muito ligado à Rebrip e incluía inicialmente: Contag, Fetraf, MST, Articulação de Mulheres Brasileiras, Marcha Mundial das Mulheres, CUT e organizações ambientalistas. Como veremos a seguir, a resposta às cúpulas sociais facilitadas pelos governos não foi homogênea.

\section{Participação nos canais institucionais do Mercosul}

As centrais sindicais foram os únicos atores com participação sustentada nos anos noventa e com canais de diálogo que reconheciam oficialmente esta participação, sobretudo com o FCES. A organização de Cúpulas Sociais e a criação do PMSP capitaneadas pela Secretaria Geral da Presidência buscaram garantir espaços mais amplos, nos quais fosse possível abrigar uma série de organizações muitos diversas que se engajaram com temas internacionais a partir do Fórum Social Mundial e das mobilizações contra a ALCA. Contudo, segundo Berrón (2013), a mudança rumo à participação institucional não ocorreu sem contradições, 
pois o fato das organizações virem de um período de intensa mobilização contra governos neoliberais e encontrarem receptividade distinta, e até a busca de diálogo, gerava algumas dúvidas e desconfianças. No caso do Mercosul, não houve uma convergência de estratégias. Grupos que já apoiavam criticamente o bloco desde o início dos anos noventa e já atuavam nas instâncias de diálogo previamente existentes, como o movimento sindical, seguiram participando nesta nova fase, embora de forma mais esvaziada. Um segundo grupo, com posições mais críticas sobre o Mercosul, como as organizações filiadas à Vía Campesina ${ }^{71}$, continuou afastado e se aproximou politicamente da ALBA, iniciativa capitaneada pela Venezuela. Por fim, um terceiro grupo, mais heterogêneo, com ONGs ligadas à educação (Ação Educativa, Instituto Paulo Freire), aos direitos humanos (IDDH, Conectas, ABLGT), aos direitos dos imigrantes (Pastoral-CAMI, CDHIC), à juventude (Conjuve), ao movimento de mulheres, bem como algumas ONGs multi-temáticas como o Ibase, o Inesc, a FASE e o Instituto Polis passaram a participar das cúpulas sociais e do Programa Mercosul Social e Participativo, não sem críticas como veremos adiante. Em casos mais específicos como a REAF, organizações sindicais rurais como a Contag e a Fetraf também passaram a atuar nos novos canais de diálogo.

Conforme visto anteriormente, o movimento sindical, puxado sobretudo pela CUT no Brasil e pela CCSCS no âmbito mercosulino, foi o principal ator da sociedade civil nos anos noventa. Representantes das várias centrais sindicais seguiram atuando nas novas instancias participativas regionais, mas sem o mesmo ímpeto anterior. Além disso, a CUT por exemplo sempre expressou uma posição crítica frente às inovações da Cúpula Social (embora este posicionamento crítico não apareça oficialmente em documentos, foi mencionado nas entrevistas tanto com

\footnotetext{
${ }^{71}$ Recentemente, após a adesão oficial da Venezuela ao Mercosul, o MST anunciou também sua participação.
} 
integrantes da central $^{72}$, quanto com o então assessor internacional da $\mathrm{SG}^{73}$ ), vista como espaço assembleísta, com muitos discursos, mas sem debates mais aprofundados e possibilidade real de incidência. Contudo, chama a atenção que este enfraquecimento da participação no Mercosul tenha tido início antes mesmo do declínio percebido no bloco nos últimos cinco anos. No caso do FCES, em parte este estancamento se deve à própria natureza do espaço, que reúne entidades sindicais e empresariais e exige consenso para emitir recomendações. Mas além disso, a Coordenadora de Centrais Sindicais do Cone Sul, que durante os anos noventa foi um dos atores mais relevantes nas demandas por participação, também apresentou declínio em sua atuação no Mercosul.

Neste ponto, mais uma vez a dinâmica continental ajuda a entender alguns posicionamentos no âmbito do Mercosul. A CCSCS se consolidou nos anos 90 a partir da percepção das diversas centrais sindicais de que 0 Mercosul poderia se constituir como um espaço adicional às lutas nacionais, por exemplo, para defender interesses sindicais contra a possível concorrência com países com menor nível de proteção trabalhista (esta era a percepção da CGT argentina com relação ao Brasil, por exemplo), ou para disputa política contra governos neoliberais (presente nas concepções da CUT). O posicionamento contra a ALCA, contudo, nunca foi consensual na CCSCS. A CGT argentina, mais próxima ao governo, nunca se opôs ao projeto hemisférico, ao contrário de centrais como a CUT e o PIT/CNT. Dessa forma, desde a criação da Aliança Social Continental e, sobretudo, no processo de "radicalização" da posição contrária à ALCA no contexto da coalizão com movimentos sociais como a Vía Campesina e os movimentos antiglobalização, houve uma progressiva divisão no interior da CCSCS, com o descolamento entre as iniciativas da cCSCS no Mercosul e de parte de suas centrais que aderiram ao movimento anti-ALCA (como a CUT, o PIT-CNT e a então recente Central

\footnotetext{
72 Entrevista com Maria Silvia Portella de Castro e com Rafael Freire Neto

${ }^{73}$ Entrevista com José Renato Vieira Martins
} 
de los Trabajadores Argentinos/CTA). Na medida em que as negociações da ALCA se intensificaram, o Mercosul entrou em crise e o movimento continental contra o livre comércio nas Américas ganhou protagonismo, a CCSCS perdeu relevância como espaço de coordenação transnacional dos sindicatos ${ }^{74}$. Como veremos adiante, as dinâmicas do Mercosul, principalmente o declínio percebido nos últimos anos, são responsáveis por boa parte da descrença por parte de organizações da sociedade civil nas possibilidades de participação. Mas no caso sindical, o desengajamento começou antes. Embora este processo não esteja diretamente ligado ao Mercosul, constitui o contexto no qual centrais sindicais extremamente ativas no bloco, como a CUT, passam a dirigir esforços e recursos para outros processos e disputas em curso. Desse modo, mesmo antes do declínio percebido no Mercosul, há um esvaziamento da agenda sindical no bloco.

As organizações integrantes da CLOC-Vía Campesina apresentaram um postura mais crítica ao Mercosul, mesmo no cenário de mudança de governos na região. A Coordenadora Latino-Americana de Organizações do Campo foi fundada em 1994, tendo como antecedente a organização da campanha continental "500 anos de resistência" contra o neoliberalismo e por ocasião dos quinhentos anos da chegada de Cristóvão Colombo às Américas em 1992. Em 1993, a partir de um encontro realizado na Bélgica, com organizações camponesas que se articulavam em outras regiões do mundo, foi fundada a Vía Campesina, em torno de uma plataforma de defesa combativa dos direitos camponeses, que nos anos seguintes consolidaria sua luta por soberania alimentar e contra o livre comércio. Por estas características, as

\footnotetext{
${ }^{74}$ Além disso, paralelamente a este processo ligado à ALCA (e em parte devido a ele) há também uma disputa dentro das estruturas do movimento sindical continental na ORIT, até então hegemonizadas pelos EUA e a AFL-CIO. Diversas crises nas organizações mais conservadoras dentro da ORIT, junto com o protagonismo do movimento contra a ALCA, abriram espaço para disputas da direção do movimento sindical continental. Mesmo depois do adiamento sine die das negociações da ALCA, esta disputa seguiu intensa por outros motivos, dentre os quais o movimento de fusão entre entidades ligadas à social democracia e à democracia cristã, que no continente resultam na fusão da ORIT e da CLAT e da criação da Confederação Sindical das Américas.
} 
organizações brasileiras filiadas à Vía Campesina (MST, MAB, MPA e MMC) têm se oposto ao Mercosul - por sua origem neoliberal, pela persistência de um modelo orientado para o livre comércio e pela falta de enfrentamento às multinacionais - e se aproximado politicamente da ALBA, que em 2009 criou seu Conselho de Movimentos Sociais. Vale registrar que este Conselho conta com movimentos de países não membros da ALBA, sendo o MST o exemplo mais expressivo no Brasil, com parcerias com o governo venezuelano para o desenvolvimento de projetos de agroecologia no país vizinho.

Como integrante da Rebrip e da ASC, o MST participou inicialmente das Cúpulas dos Povos do Sul, mas foi progressivamente se afastando em direção à ALBA. A organização também esteve presente pontualmente em algumas Cúpulas Sociais, mas em linhas gerais a CLOC e a Vía Campesina mantêm postura distante das iniciativas de participação social, com uso preponderante dos repertórios de confronto (Martinez-Torres e Rosset, 2010; Borras, 2008). Esta posição não aparece de forma explícita em documentos, ao contrário, é justamente o silêncio sobre o Mercosul e a presença central da ALBA que permitem entrever o distanciamento ${ }^{75}$. Recentemente, depois da plena adesão da Venezuela ao Mercosul, o MST anunciou sua participação no bloco, mas na prática esta aproximação não se traduziu numa mudança expressiva ou na aproximação das organizações da CLOC com os canais de diálogo do bloco.

Por outro lado, as outras duas grandes organizações brasileiras do campo, Contag e Fetraf, filiadas à CUT, participam desde o início da $\mathrm{REAF}^{76}$, do PMSP e das Cúpulas Sociais. Em dissertação sobre o tema,

\footnotetext{
75 O silêncio frente aos convites por parte da SG para o PMSP e as Cúpulas Sociais também foi relatado em entrevista com José Renato Vieira Martins.

76 Além da Contag e da Fetraf, participam da REAF: o Movimento Interestadual das Quebradeiras de Coco Babaçu (MIQCB), o Conselho Nacional de Populações Extrativistas (CNS), o Movimento das Mulheres Trabalhadoras Rurais do Nordeste (MMTR-NE), o
} 
Carvalho relata que a decisão da Contag e da Fetraf de participarem do Mercosul se dá muito mais pela valorização da dimensão transnacional da disputa política em si, do que propriamente por motivos puramente domésticos, já que o processo de abertura do Mercosul para as organizações do campo ocorre num momento de abertura institucional também no Brasil, com a criação do $\mathrm{MDA}^{77}$.

O grupo de ONGs que passa a participar dos novos espaços no Mercosul é bastante diverso, compreendendo ONGs multitemáticas com maior estrutura, que vinham tendo um papel bastante importante de assessoria aos movimentos sociais nos temas do livre comércio (como a FASE, o Ibase, o Inesc), além do Instituto Polis e de ONGs relativas a temas específicos como educação (Ação Educativa, Instituto Paulo Freire, Campanha Nacional pelo Direito à Educação), saúde (ABIA), diversidade sexual (ABGLT), migrantes (CAMI e CDHIC), gênero (Instituto Equit, UBM, FDIM), direitos humanos (Conectas, IDDH), racial (Unegro, Conen, APJN), juventude (UNE, Engajamundo, Geomercosul juvenil, Conjuve) e pequenos e médios empresários (Alampyme).

Nas organizações que se engajaram ativamente nas articulações contra o livre comércio (como FASE, Ibase e Instituto Eqüit) a decisão de participar dos novos canais no Mercosul está muito associada à Rebrip, cuja própria formação está ligada ao acompanhamento dos temas comerciais. Vale lembrar que nos anos imediatamente posteriores ao fim das negociações da ALCA, a Rodada Doha e a negociação do acordo Mercosul-UE -

Departamento Intersindical de Estudos Rurais (Deser) e a Rede Brasileira pela Integração dos Povos (Rebrip).

77 Dentre os motivos que levaram as organizações rurais a participar da REAF e manter seu engajamento, Carvalho identifica dois grupos principais. Por um lado, organizações paraguaias veem nesta instância institucional a possibilidade de alavancar suas demandas e pressionar seu governo para que efetive políticas de apoio à agricultura familiar, no mesmo padrão bumerangue descrito anteriormente, ou seja, a ação é transnacional, mas as questões são ainda domésticas (2011:98). Por outro lado, as declarações da Contag, da Fetraf e da Rebrip mostram a percepção do espaço da REAF menos como extensão do nacional, e mais como um local adicional de disputa de projetos, tanto de afirmação da agricultura familiar, como da integração regional. Há preocupação premente com a reunião de forças para uma disputa política que é travada fora dos países, no campo regional (2011:111) 
lançada oficialmente em 2004 - ainda estavam no horizonte, de modo que ainda havia interesse na transparência com relação ao conteúdo das negociações:

É um período de muita agitação, de muita mudança nos processos organizativos da sociedade civil e nesses processos nós começamos a exigir uma maior presença da sociedade civil, criar momentos de debate, seminários, em relação ao Mercosul, e que são simultâneos às negociações da ALCA e com a UE, que começam em 2004 e reforçam a necessidade da sociedade civil participar via Mercosul, sobretudo a partir do tema da transparência das negociações. ${ }^{78}$

A mudança no cenário político também é percebida por estas organizações como uma oportunidade para a atuação, tanto por meio de mobilizações, quanto pela participação. Um documento da Rebrip, de balanço e avaliação do período 2005-2007, afirmava:

Aqui no Brasil, com o início do governo Lula em 2003, a REBRIP seguiu seu compromisso com as mobilizações do lado de fora, mas passou a também jogar o jogo do lado de dentro, diante da possibilidade aberta pelo governo de participarmos de instâncias nacionais e de delegações oficiais nas negociações continentais e multilaterais (...)No ambiente da REBRIP e da ASC as percepções são de que as chances da conjuntura na América do Sul têm a ver com uma combinação entre quebra de hegemonia do neoliberalismo, ie, formação de um ambiente distinto dos anos 90, ascensão de movimentos de resistência que se traduziram na eleição de governos mais permeáveis e sensíveis às demandas populares, e o fato do imperialismo estar mais voltado para o Oriente Médio do que para a América Latina. Estes fatores abrem na região um momento sem precedentes, que nos desafia a pensar em um projeto contra-hegemônico no plano regional, e que, sobretudo, nos obriga a dialogar com as perspectivas e propostas concretas que estão sobre a mesa e não mais com debates em tese. (Rebrip, 2007)

As entrevistas revelam também que o ideal participativo, disseminado entre organizações da sociedade civil brasileira, e a expectativa gerada pela chegada do Partido dos Trabalhadores ao governo federal - dada a experiência prévia do orçamento participativo em administrações locais animaram a participação inicial no canário pós-ALCA. Alguns trechos ilustram este sentido:

\footnotetext{
${ }^{78}$ Entrevista com Graciela Rodríguez, Instituto Eqüit/Rebrip
} 
Eu acho que a historia da participação é associada às mudanças de governo a partir de 2002. Todo projeto que vem no bojo da eleição do $P T$, que depois vai ser verificar não é exatamente o mesmo, ele vem com uma ideia de transformar a sociedade, buscar equidade, justiça social, inclusão, acabar com a pobreza, e nesse âmbito, a expectativa de uma integração regional, da nossa parte trazia esses elementos de defesa de direitos também (...) a gente se envolveu pensando que o projeto de transformação de sociedade que estava sendo gestado no Brasil, deveria também buscar sensibilizar e envolver o plano regional. ${ }^{79}$

(...) o tema da participação é sempre um tema extremamente relevante, da constituição de instancias democráticas, de participação, bom e a gente aqui no Brasil com o inicio de uma experiência do PT muito positiva em termos de participação, Porto Alegre, orçamento participativo, toda uma esperança de uma institucionalidade democrática da base à cúpula, que vai dos tema locais aos temas globais, desde a discussão do orçamento participativo, à metrópole, à região à discussão latino-americana, dentro desse conjunto de uma certa ascensão e de um momento de passagem entre a ascensão dos movimento sociais, a consolidação do PT começo da década de 80 , de uma certa forma a criação de um instrumento politico que tem origem nos movimentos sociais $^{80}$

Além disso, para muitas ONGs dedicadas a temas específicos, as Cúpulas Sociais e o PMSP significaram o primeiro espaço de participação relativo à integração, já que estas organizações não eram (e não são) contempladas no FCES e possuem uma agenda específica para além da questão das negociações comerciais, como a agenda de educação, direitos humanos e migrações. Em casos nos quais houve algum avanço, os espaços participativos são bem avaliados, ainda que não sejam o âmbito exclusivo de articulação deste movimentos. Este posição foi relatada, por exemplo, na entrevista com Tania Rocio, coordenadora do CDHIC, que associa a conquista do Acordo de Residência às reivindicações dos movimentos sociais de imigrantes tanto dentro dos espaços institucionais, quanto na articulação extrainstitucional da Rede Espaço Sem Fronteiras. Uma perspectiva positiva também foi a tônica da entrevista com Salete Valesan, integrante da direção do Instituto Paulo Freire até 2010 e atual diretora da Flacso no Brasil, para quem a atuação

\footnotetext{
${ }^{79}$ Entrevista com Silvio Caccia Bava, Instituto Polis/Le Monde Diplomatique

80 Entrevista com Moema Miranda, diretora do Ibase
} 
das organizações da sociedade civil foi fundamental para o avanço do tema das escolas de fronteira ${ }^{81}$.

Apesar das leituras otimistas com relação aos canais de participação social no Mercosul e de algumas conquistas setoriais, há nos últimos anos um significativo desencantamento com relação a estes espaços. A fala de uma entrevistada que ainda participa do PMSP e das Cúpulas Sociais retrata: as últimas Cúpulas Sociais foram um sofrimento! Outro entrevistado que já não acompanha mais o processo diz: cada reunião era uma frustração, até um momento que falei assim, não vou mais, não adianta. É preciso ressaltar que grande parte das críticas se situam dentro do "campo progressista". Um documento da Rebrip, de avaliação da política externa brasileira, datado de 2010, mostra este sentido:

(...) houve avanços significativos nas consultas e processos de ampliação da participação de organizações e movimentos sociais nas agendas de negociações internacionais. "Nunca antes na história desse país" houve tanta participação deste campo de organizações em delegações oficiais, seja nas negociações da ALCA, OMC ou mais recentemente na COP15. Foram abertos espaços para a divulgação de informações sobre as posições do Brasil nestes fóruns internacionais, foram realizadas inúmeras consultas setoriais, mas os esforços de consolidação e fortalecimento institucional desta participação ficaram muito aquém do necessário. Processos como o Mercosul Social e Participativo ficaram longe de se posicionar no núcleo central do processo decisório. O resultado deste frágil arcabouço institucional é que os setores empresariais que historicamente consideram o processo de tomada de decisão sobre política externa algo do domínio privado deles continuaram exercendo pressão real por dentro dos gabinetes, ministérios e salas fechadas. (Rebrip, 2010)

\footnotetext{
81 Entrevista com Salete Valesan, ex-diretora do Instituto Paulo Freire e atual representante da Flacso no Brasil: Quando foram criados os institutos federais, a gente [organizações da sociedade civil] começou a forçar a ideia de que as fronteiras não podem ser delimitadas por uma estrada ou por um fio, em várias fronteiras foram criadas escolas, que são tidas como escolas irmãs, escolas de fronteira, que impacta também na questão da migração. $E$ a questão da migração vem impactando cada vez mais no reconhecimento dos sujeitos que vivem nos países do Mercosul.

O Programa Escolas Interculturais de Fronteira (PEIF) é desenvolvido no âmbito do Mercosul em cidades brasileiras da faixa de fronteira, com a atuação conjunta de docentes em "escolas-gêmeas" e a construção comum dos planos pedagógicos, dentro do marco referencial de desenvolvimento curricular do Mercosul. Está em discussão um marco referencial também para a implementação de Institutos de Fronteira. http://educacaointegral.mec.gov.br/images/pdf/documento_referencial_mercosul.pdf
} 


\section{Desencontros com o Mercosul}

Em grande parte das entrevistas o desencantamento com os mecanismos participativos está associado à baixa incidência permitida por estes espaços, à sobreposição de iniciativas regionais, sem um projeto político claro para o Mercosul e, no limite, às próprias dificuldades de aprofundamento da integração no bloco. O próprio cenário se modificou, com o impacto da crise econômica internacional iniciada em 2008 e ainda presente, com o aprofundamento de dificuldades econômicas nos países da região e a total ausência de respostas coordenadas frente à crise. Falar sobre continuidades e mudanças da política externa dos governos Lula e Dilma é um tema sensível entre algumas organizações da sociedade civil, mas as entrevistas refletem uma percepção difusa de que há uma diminuição da prioridade dada à integração regional. A votação do Banco do Sul, iniciativa considerada importante pelas organizações, está paralisada no Congresso. Acordos bastante celebrados, como o Sistema de Pagamento em Moeda Local entre Brasil e Argentina, funcionam de forma tímida, devido às restrições do Banco Central brasileiro em acumular divisas do país vizinho.

No tema da participação das organizações da sociedade civil, grande parte dos entrevistados relata um período de relativo otimismo entre 2005 e 2010, seguido por certo desencantamento, em graus variados, a partir de 2011.

\section{Fragilidades das instâncias participativas}

Como foi mencionado anteriormente, a criação de novos canais de diálogo foi inicialmente bem recebida por organizações da sociedade civil, dado que a ampliação de mecanismos participativos era uma demanda recorrente de várias destas organizações. Dito isto, a avaliação de que os 
atuais canais são extremamente limitados esteve presente em todas as entrevistas realizadas.

O PMSP é a instância considerada inicialmente mais promissora, na medida em que seu modelo se assemelha em alguns pontos aos conselhos gestores, que foram fortalecidos e ampliados no âmbito do Estado brasileiro a partir de $2003^{82}$. Mas ainda assim, a falta de uma agenda clara, a falta de seguimento das deliberações junto a outros órgãos do governo e do Mercosul e a limitação a "temas sociais" são as limitações mais frequentes citadas pelos entrevistados.

Em primeiro lugar, destaca-se o pouco tempo entre a convocação e a realização das reuniões, bem como a ausência de agendas específicas que, segundo um dos entrevistados, dificulta a preparação de intervenções qualificadas no debate. Um dos entrevistados agrupa estas questões em torno da ideia de "pré-requisitos" para a participação:

(...) para ser propositivo, para ser afirmativo, você precisa ter um preparo, uma formação, tempo para elaborar as coisas, informações, então a gente vai procurar as informações no Itamaraty e eles nos oferecem aquele livro que tem uma cronologia do Mercosul (...) você não vai numa reunião sem agenda e eu fui daqueles que pedia nas reuniões do Mercosul com a diplomacia que se fizesse uma ata, porque senão virava uma conversa de amigos. E estava desse jeito, era uma conversa em que eles formalmente cumpriam um papel, se reuniam conosco, e nós formalmente íamos buscar o espaço da participação, e tudo ficava nesse $p e^{83}$.

Além da ausência de preparação prévia, a falta de consequências e de seguimento do que é debatido também está presente em algumas avaliações. A comparação de uma entrevistada com a dinâmica do Conselho de Segurança Alimentar é ilustrativa:

\footnotetext{
82 Ainda que não tenhamos avaliações sobre o impacto, de 2003 a 2014 foram criados 23 Conselhos no âmbito federal e organizadas 102 Conferências Nacionais em 46 temas de políticas públicas, No período anterior, de 1992 a 2002 foram 27 conferências em 12 áreas.

83 Entrevista com Silvio Caccia Bava, Instituto Polis/Le Monde Diplomatique
} 
Quando a gente olha por exemplo o que acontece no Consea, que é uma experiência de conselho mais sólido do ponto de vista institucional, o Consea também não é deliberativo, mas as discussões viram recomendações à Presidência, então cria-se pelo menos um custo politico, aquilo vira um documento oficial e você cria um custo politico se não forem pelo menos debatidos aqueles assuntos. No Mercosul Social e Participativo você chega lá, fala, fala, fala e não tem nada depois disso. E ao mesmo tempo o setor empresarial por fora fazendo o que faz sempre, que são seus canais privados de pressão, emplaca seus interesses no Mercosul na Camex, etc. ${ }^{84}$

Um terceiro ponto, citado em todas as entrevistas, é a limitação dos espaços consultivos aos "temas sociais", tanto no PMSP, quanto nas Cúpulas Sociais:

O que a galera não aguenta mais é isso, a dinâmica econômico produtiva fica com as empresas e a gente vai discutir o social. Isso que precisa ser mexido ${ }^{85}$.

Quando, por exemplo, a gente começou a discutir a questão do Focem, o que nos foi dito foi: "ah o dinheiro já está comprometido para os próximos 8 anos", então não tem conversa ${ }^{86}$.

(...) os governos pensam que nós devemos nos ocupar dos temas sociais, o instituto social do Mercosul, o plano de estratégico de ação social, dos direitos humanos, não, eu quero saber os acordos com a UE, quero a denúncia do acordo com Israel, quero o tema de quais são as implicações do Tratado com Israel sobre a questão do armamento para as Olimpíadas, não quero só saber dos temas sociais, quero saber se a linha de energia de Itaipu para Assunção significou um interesse dos empresários paulistas pra se instalar, enfim esta temática também nos interessa para além dos temas da migração, além dos laborais, além dos temas de gênero, temos que ter acima de tudo transparência e no Mercosul não há transparência sobre as negociações ${ }^{87}$.

No caso das Cúpulas Sociais, as possibilidades de incidência são ainda menores, na medida que reúnem uma série de organizações da sociedade civil em eventos paralelos às Cúpulas oficiais do Mercosul, mas sem interação concreta com os órgãos decisórios (interação é restrita à

\footnotetext{
${ }^{84}$ Entrevista com Fátima Mello, FASE/Rebrip

85 Entrevista com Fátima Mello, FASE/Rebrip

86 Entrevista com Silvio Caccia Bava, Instituto Polis/Le Monde Diplomatique

${ }^{87}$ Entrevista com Graciela Rodríguez, Instituto Equit/Rebrip
} 
entrega do documento final) e sem mecanismos que garantam 0 seguimento do que foi decidido nas cúpulas.

\section{Dilemas da autonomia}

As preocupações com a autonomia por parte dos movimentos têm sido um tema constante. Em primeiro lugar, a apropriação do repertório de cúpulas paralelas pelos governos gerou dúvidas e desconfianças, tanto entre as organizações da sociedade civil, quanto no interior do próprio governo. De acordo com o ex-assessor internacional da SG na época da primeira Cúpula Social ${ }^{88}$, o Ministro Luiz Dulci teria ponderado esta questão e expressado a necessidade de que fosse decidido "qual o gene dominante e qual o gene recessivo" nessa relação Estado/organizações da sociedade civil. Estas diferentes concepções foram precariamente equacionadas enquanto foram realizadas as cúpulas autônomas dos movimentos sociais (Cúpula dos Povos do Sul). A partir de 2010, estas tensões se concentraram nas Cúpulas Sociais e no PMSP. Embora as organizações da sociedade civil entrevistadas reconheçam que haja esforço do governo brasileiro em garantir um momento próprio para a sociedade civil e que a escolha das organizações que serão financiadas para participar da cada Cúpula Social seja feita de forma autônoma e respeitada pelo governo, as diferentes dinâmicas entre Estado e sociedade civil em cada país membro do bloco dificulta a construção de um formato unificado. Em segundo lugar, não há critérios unificados para a realização das Cúpulas Sociais e cada país tem concepções e práticas diferenciadas sobre a relação Estado/sociedade civil. Além disso, a Cúpula social só é organizada pelo governo brasileiro quando o país exerce a Presidência Pro Tempore, que muda a cada seis meses. Isso significa que dinâmica de cada reunião é bastante dependente da PPT em turno.

${ }^{88}$ Entrevista com José Renato Vieira Martins, ex-assessor especial da SG-PR 
Justamente as diferentes formas de se tratar a questão da autonomia têm gerado muita discussão entre organizações da sociedade civil brasileira. Este é um tema sensível para várias organizações participantes, na medida em que mesmo que tenham críticas a determinadas práticas em países vizinhos, se reconhecem num mesmo campo político. Estas tensões foram evidentes durante a observação participante da Cúpula Social realizada em dezembro de 2012 em Brasília e, em algumas reuniões do PMSP nos anos de 2013 e 2014. A reunião do PMSP realizada em setembro de 2014 no Palácio do Planalto, pouco tempo depois da primeira Cúpula Social realizada na Venezuela e de uma reunião para a implementação do Fórum de Participação Cidadã da Unasul em Cochabamba expôs estas tensões de forma dramática. Esta percepção também surgiu em algumas entrevistas, uma das quais expõe o tema de forma bastante clara:

\begin{abstract}
Essa participação social por mais que ainda seja promovida e seja apoiada pelos movimentos sociais, ela tem um lado que é complexo pra nós, que é esta divisão tênue entre o que é autonomia e o que são os governos que determinam, sendo que há muita diferença no caso do Mercosul de como os governos assumiram a questão da participação, criando às vezes enfrentamentos fortes na própria sociedade civil sobre a relação dos movimentos com os governos e o formato que isso traz para o próprio mecanismo de participação da sociedade civil. Me lembro que nas duas ultimas duas ou três reuniões, sobretudo aqui no Brasil, o tema da autonomia dos movimentos com relação aos governos tem sido motivo de briga muito forte $(. . .)^{89}$
\end{abstract}

Percebe-se portanto que a falta de critérios claros para a realização das Cúpulas, sobre quem participa e é financiado não tem contribuído para a geração de dinâmicas transnacionais, ao contrário. Há uma tensão persistente com relação ao tema da autonomia e do aparelhamento das Cúpulas por parte de alguns Estados, com uma avaliação mais positiva do Brasil e do Uruguai. A mesma entrevistada menciona ainda:

Cúpulas Sociais estão se tornando um lugar pouco produtivo em termos do que é a aproximação da sociedade civil dos diferentes países. Um

${ }^{89}$ Entrevista com Graciela Rodríguez, Instituto Equit/Rebrip 
dos grandes objetivos da Cúpula Social é essa interação, esse intercâmbio entre as sociedades civis dos países do grupo que está se integrando, no caso o Mercosul, então isso seria importantíssimo e acaba não sendo, porque no caso da Venezuela foi muito difícil com o governo venezuelano, no caso da Argentina também, e no Paraguai nem se fala porque não tem interesse, enfim então o papel dessa participação acaba ofuscado por uma disputa que não é a mais importante, ou seja você acaba disputando com a sociedade civil entre os países em lugar de estar vendo o conteúdo das negociações, o debate sobre os temas do Mercosul ${ }^{90}$

\section{Um projeto político para o Mercosul}

Um segundo tema, que dialoga diretamente com o enfraquecimento das estratégias de mobilização e com o desencantamento com a participação institucionalizada, é a falta de um projeto político claro para o Mercosul, em coordenação com outras iniciativas regionais, como a Unasul. Em linhas gerais, apesar das diferenças que serão explicitadas, a percepção é que o Mercosul deixou de ser um espaço de decisões importantes, os temas de maior relevo migraram para outras instâncias (agenda de infraestrutura na Unasul e impacto ambiental) ou não têm sido equacionados em nenhum fórum (cooperação econômica, respostas coordenadas frente à crise, integração produtiva)

Por parte da CUT e da CSA, a avaliação é que justamente a falta de integração da agenda econômica fragiliza a própria coordenação política, compreendida como um avanço:

Não avançamos na complementariedade econômica. O que avançamos politicamente (entrada da Venezuela no Mercosul, construção da Unasul) não é refletido na economia, e aí somos mais vulneráveis frente aos ataques externos. (...) Politicamente temos região que está sintonizada, mas que não reflete isso nas respostas aos problemas nacionais da economia. Do ponto de vista da América do Sul não temos nenhuma articulação que responda à crises [econômicas]. ${ }^{91}$

\footnotetext{
90 Ibidem

91 Entrevista com Rafael Freire Neto, CSA/CUT
} 
Lembrando que a ênfase na integração produtiva está na agenda sindical desde 1992, na época ofuscada por uma pauta que centrou esforços na liberalização comercial. Contudo, a perspectiva pós-liberal não trouxe avanços significativos para o "núcleo duro" da integração, que segue vulnerável, agora também frente às potências emergentes:

Desde a criação dos BRICS, a Rebrip vem defendendo a importância de ser cabeça de suas regiões. A China construiu uma importância regional enorme, o Brasil se perdeu um pouco nessa história.(...) Integração política não se expressa em projetos comuns, o Banco do Sul naufragou, não sai do papel há anos, Brasil nunca teve interesse. ${ }^{92}$

As avaliações não minimizam a importância do avanço em outras dimensões da integração, a questão é a dificuldade de impulsionar e avançar nestas outras dimensões frente às dificuldades de aprofundamento do Mercosul

(...) questão é que falta uma pauta concreta, falta principalmente a alavancagem de um projeto politico paro o Mercosul, que nos convoque a atuar sobre ele, seja para apoiar ou para tensionar. Por exemplo, vamos criar uma agenda de direitos humanos, tá, mas no que isso encaixa num projeto de integração do Cone Sul? ${ }^{93}$

Se a Unasul desse certo em todos os seus aspectos automaticamente aos poucos o próprio Mercosul estaria contemplado ali, mas pra isso acontecer o processo da unasul precisa se constituir e se efetivar. ${ }^{94}$

E o fato da Venezuela ter ingressado, tentativa de ampliação é o ponto de partida mais consolidado que a gente tem, o que falta é aproveitar este ciclo de governos enquanto eles estão aí pra processar Mercosul Unasul, as iniciativas mais no âmbito ALBA, tentar juntar tudo isso e fazer um balanço e uma perspectiva de futuro. Eu sempre fico achando que tudo que tá se discutindo, Celac, Unasul, é como se fossem novas camadas que não processam o que já se acumulou na trajetória do Mercosul. O que na trajetória do Mercosul está sendo absorvido na Celac mesmo? Ou é um novo troço? Os encaixes entre as dinâmicas, não vejo muito acontecer. ${ }^{95}$

\footnotetext{
92 Entrevista com Graciela Rodríguez, Instituto Equit/Rebrip

93 Entrevista com Fátima Mello, FASE/Rebrip

94 Entrevista com Salete Valesan, Instituto Paulo Freire/Flacso

95 Entrevista com Fátima Mello, FASE/Rebrip
} 
No âmbito da Unasul, entre as ONGs multi-temáticas, como a FASE e o Ibase, que trabalham também com o tema da justiça ambiental, cresce a percepção da integração regional como uma "agenda negativa". Isso porque as áreas de maior avanço foram impulsionadas justamente pela expansão dos interesses de empresas brasileiras na região, com financiamentos do BNDES, seja na área de petróleo e gás, seja em serviços de engenharia para construção da infraestrutura, que fortalecem um modelo de exportação de commodities para o mercado internacional de reprimarização da economia brasileira e sul-americana, que é prejudicial do ponto de vista da integração produtiva, insustentável do ponto de vista ambiental e violador dos direitos de populações indígenas e ribeirinhas impactadas pelos mega-projetos ${ }^{96}$.

De um lado tem povos indígenas, populações tradicionais, camponeses, que são deslocados de seus territórios por projetos financiados pelo BNDES na região ou pela exploração de petróleo pela Petrobras. É um contingente grande que olha a integração como uma agenda negativa, integração é sinônimo da expansão das empresas brasileiras pra cima dos territórios dessas populações, mas é claro que ao mesmo tempo essas forças tem uma agenda própria de integração (vamos nos unir contra o avanço dos empreendimentos, vamos realizar nossa agenda de bem viver). Acho que a gente tem que trazer essas forças, o impactados pra dentro da discussão de integração, não dá mais pra gente ficar discutindo integração com forças que são do campo de esquerda ficando do lado de fora. ${ }^{97}$

Desse modo, na medida em que a integração liderada pela expansão das empresas brasileiras é percebida como uma agenda negativa, novas articulações reativas de caráter transnacional começam a ser desenhadas, com a criação de novas redes como a Rede Latino-

\footnotetext{
96 Segundo estudo do Ibase, de 2000 a 2010 a participação da indústria extrativa mineral no PIB brasileiro cresceu 156\%. Em 2011 o Brasil produziu cerca de US $\$ 50$ bi em minérios, dos quais mais de $90 \%$ é exportado, o que responde por quase $20 \%$ das exportações nacionais, tendo a China como principal comprador. Através de uma subsidiária, BNDESPAR, o BNDES investe pesado nas empresas do setor de mineração, petróleo e gás. A crítica das organizações ambientalistas é que o Estado está investimento num modelo de desenvolvimento insustentável (reprimarização e problema ambiental)

${ }^{97}$ Entrevista com Fátima Mello, FASE/Rebrip
} 
Americana sobre Indústrias Extrativistas (RLIE) e o Observatório LatinoAmericano de Conflitos Mineiros.

É sintomático que os esforços de algumas destas organizações estejam atualmente voltados para outros espaços. Para retomar o eixo em torno da percepção sobre estruturas de oportunidades políticas, não foi a abertura simultânea nacional e regional que enfraqueceu a atuação das organizações da sociedade civil no bloco, mas a própria dificuldade de aprofundamento, ou ainda sua enfraquecimento como uma estrutura de oportunidade ou ameaça. Um dos trechos finais de uma entrevista resume este ponto:

Essa historia do Mercosul se esvaziar como espaço de integração econômica, comercial, financeira, também deu uma falta de interesse generalizado porque aí os movimentos sociais não viam ali nenhum âmbito real de disputa de interesse, de forças. 


\section{Capítulo IV}

\section{O reencontro com as hipóteses de trabalho}

Como considerado no primeiro capítulo, a partir da influência da abordagem do processo político no estudo de movimentos sociais, a literatura sobre o transnacionalismo traz para o centro de sua análise a ideia de estruturas de oportunidades políticas, particularmente por meio da interação entre os planos institucionais domésticos e internacionais. Tarrow e Della Porta (2005) identificam quatro conjuntos de mecanismos que ligam os dois planos: difusão, internalização, externalização e ação coletiva transnacional. A partir de seus trabalhos anteriores, Sikkink (2005) propõe uma sistematização dos padrões de ativismo transnacional esperado de acordo com variações no nível de acesso às estruturas de oportunidades políticas. Os diferentes cenários de mobilização que conectam os planos doméstico e internacional dão origem a novos formatos de organização e de ação coletiva em âmbito transnacional. Quando o canal de acesso às instituições domésticas está bloqueado ou o governo nacional é pouco permeável às demandas dos movimentos, teríamos o ativismo típico do padrão bumerangue, no qual o ambiente internacional, por meio de regimes e normas pode embasar a as reivindicações de movimentos sociais e seus parceiros em redes transnacionais e, com a pressão de Ols e outros Estados, pode aumentar a visibilidade destas demandas (Sikkink e Keck, 1998; Sikkink e Risse, 1999). Por outro lado, quando o ambiente internacional é visto como fonte de ameaça, de potencial restrição à margem de atuação de Estados, como em casos relacionados ao acordos do FMI, da OMC ou ainda acordos de livre comércio, teríamos um cenário propício para a formação de coalizões transnacionais de tipo defensiva, buscando evitar perdas potenciais (Von Büllow, 2010; Berron, 2007; Kay, 2011). Finalmente, quando os planos doméstico e internacional são percebidos como 
favoráveis às demandas das organizações da sociedade civil, o ativismo tenderia a concentra-se no nível doméstico, usando as estruturas de oportunidades políticas internacionais como estratégia complementar (Sikkink, 2005). Por sua vez, a partir do ativismo sindical no Nafta, Kay (2011) argumenta que a criação de canais oficiais de diálogo com organizações da sociedade civil em estruturas internacionais de governança poderia fomentar a construção de relações transnacionais.

Em diálogo com esta literatura e a partir do caso do Mercosul, as hipóteses de trabalho desta pesquisa eram que: 1) embora a abertura simultânea das estruturas de oportunidades políticas doméstica e regional preconizasse a diminuição do ativismo transnacional, a existência de mecanismos participativos geraria incentivos que poderiam manter a atuação das organizações da sociedade civil, inclusive com um caráter mais sustentado ao longo do tempo (e não apenas em torno de campanhas transnacionais), constituindo novos temas e atores; e 2) o declínio da atuação das organizações da sociedade civil em torno da integração regional no Mercosul não seria portanto reflexo da abertura das estruturas de oportunidades políticas doméstica e regional, mas sim reflexo da própria dificuldade de aprofundamento do Mercosul como uma instituição regional de governança, ou seja, seu enfraquecimento como uma estrutura de oportunidade política.

A atuação de organizações da sociedade civil no Mercosul ao longo dos anos mostrou que reinvindicações de instâncias de consulta estiveram presentes desde o início entre o movimento sindical e que também desde os anos noventa as pressões e mobilizações extrainstitucionais se combinavam com a participação nos canais institucionais do bloco primeiro com o movimento sindical e posteriormente com a ampliação do número de organizações da sociedade civil, incluindo uma série de ONGs e movimentos sociais. 
O primeiro acontecimento neste sentido ocorreu com o reconhecimento da participação das centrais sindicais no subgrupo relativo à questões trabalhistas, seguridade social e emprego, seguido pela constituição do FCES no Protocolo de Ouro Preto. Estas inovações foram em grande medida fruto da pressão das centrais sindicais que, durante o processo, construíram uma coalização transnacional em torno da Coordenadora de Centrais Sindicais do Cone Sul. Na fase de transição, entre o Tratado de Assunção e o Protocolo de Ouro Preto, estas ações transnacionais procuraram incidir sobre os rumos da integração e minimizar as perdas potenciais para os trabalhadores dos países do bloco que, na percepção dos sindicatos, viriam com a assinatura de um tratado de orientação liberal, sem mecanismos de compensação e redução de assimetrias. Diante do fracasso inicial das reivindicações, depois do Protocolo de Ouro Preto e tendo ainda algum grau de supranacionalidade no horizonte, a CCSCS passou a pressionar pela inclusão de mecanismos regionais de proteção social e trabalhista, que pudessem servir como uma arena adicional de pressão nas lutas nacionais. Em 1998, além da Declaração Sócio-Laboral, o Mercosul criou uma Comissão encarregada de monitorar os direitos previstos na Declaração que, embora não tivesse/tenha poder vinculante, teria como função pressionar e promover a melhoria do respeito aos direitos sociais e trabalhistas nos quatro países do bloco. Esta disputa política não se deu apenas pelos tradicionais repertórios de confronto político, mas foi também canalizada para os canais de participação no âmbito regional, além dos contatos informais entre líderes e assessores sindicais e integrantes do MTE e do MRE, no caso brasileiro. Nesta fase, além de referências gerais a canais de consulta às sociedades, a participação sindical tinha como foco incidir sobre normas concretas (como ritmo da liberalização, necessidade de políticas compensatórias, carta de direitos fundamentais) que, se criadas no âmbito da integração regional, poderiam impactar a agenda sindical. A resolução do $6^{\circ}$. Congresso da CUT, realizado em 1997 ilustra este aspecto: 
A defesa e ampliação dos direitos sociais e da legislação trabalhista no interior dos blocos comerciais regionais (NAFTA, ALCA, Mercosul etc.) tem sido uma das principais estratégias para promover o combate ao déficit social e democrático que caracterizam essas iniciativas. Exigir o cumprimento desses direitos pelos governos e empresas transnacionais, que se favorecem das facilidades tarifárias no interior desses blocos, deve ser uma prioridade da CIOSL e das organizações afiliadas. Compete à CUT ampliar as pressões sobre o governo brasileiro em favor da dimensão social e adoção da Carta Social do Mercosul. (CUT, 1997)

A partir de 1998, o lançamento oficial das negociações da ALCA transforma significativamente o panorama regional, porque reúne uma série de organizações diversas numa coalizão multi-setorial e porque, ao longo do processo, radicaliza a posição das organizações da sociedade civil contra o livre comércio. Se no início das articulações continentais, empreendidas por iniciativa dos sindicatos em 1997, as reivindicações eram por transparência e participação no processo (à semelhança dos espaços garantidos para o setor empresarial), a partir de 1999, com a explosão do movimento antiglobalização e o fortalecimento da coalizão continental com a inclusão de novas organizações, o posicionamento passa a ser de rejeição à ALCA e, neste momento, a participação nos frágeis canais oferecidos pelos Estados deixa de ser uma estratégia (Berron, 2007). Além disso, a construção de uma coalizão continental ampla entre sindicatos, movimentos sociais e ONGs não se dá apenas de forma instrumental, mas também pela construção comum de significados e sentidos para esta luta. Acomodar esta pluralidade de posições nas declarações políticas tornou-se um desafio crescente. Segundo Von Büllow (2010:157), inicialmente o documento Alternativa para as Américas, da Aliança Social Continental, refletia as posições dos "veteranos do Nafta", mas ao longo de sucessivas edições, deixa de ser referenciado apenas na luta contra a ALCA e passa a incluir uma perspectiva mais ampla, com a criação de uma "nova sociedade". Segundo a autora, dentre os pontos recorrentes nos documentos, há uma demanda pelo fortalecimento da capacidade regulatória dos Estados frente à iniciativas privada e à globalização, respaldado pela ênfase na 
soberania popular por meio da democracia participativa. Na última versão do documento há referências recorrentes a este último aspecto:

Los debates, las decisiones y la construcción de marcos de negociación en asuntos de integración económica han sido tradicionalmente dominados por las élites del sector financiero, corporativo $y$ gubernamental. Hay que introducir una mayor democratización en la toma de decisiones en torno a la política comercial y a las inversiones. Los acuerdos internacionales deben ser ratificados en una consulta directa a los ciudadanos, en los cuales pueden tomar formas de plebiscitos o referéndum nacionales. (...) La democracia, además, no debe reducirse a lo electoral. Es necesario introducir la democracia en la toma de las decisiones económicas y sociales fundamentales. Los ciudadanos no sólo deben aprobar la orientación económica y social, sino participar en su diseño, implementación y evaluación. También deben poder cambiarla o ajustarla en cualquier momento.(ASC, 2005:9)

Pode-se afirmar portanto que, com a ampliação dos setores mobilizados na luta contra a ALCA e com o crescimento de visões críticas aos processos de globalização no final da década de noventa, cresce também a percepção de que a formulação de política externa no âmbito das negociações comerciais é bastante permeável aos interesses das grandes corporações, em detrimento de vários setores sociais, cujos interesses não se viam refletidos na política externa dos Estados. $O$ documento da ASC liga este fato à limitação da democracia ao momento eleitoral e afirma a necessidade de se ampliar a democratização das decisões via participação dos cidadãos. Parece correto afirmar que a amplitude das mobilizações contra a ALCA e do movimento altermundialista na virada do milênio sensibilizaram para o tema internacional vários setores sociais até então focados no terreno doméstico e lançaram luz sobre a opacidade do processo de formulação de política comercial em particular, e da política externa em geral.

No Brasil, a chegada do Partido dos Trabalhadores ao governo federal muda expressivamente o contexto político para estas organizações da sociedade civil. Desde o início da integração regional no Mercosul, o partido se posicionava contra um modelo de integração baseado 
exclusivamente na liberalização comercial $^{98} \mathrm{e}$, embora a ASC não permitisse a participação oficial de partidos políticos, o PT estava presente indiretamente na Aliança por meio de militantes que também eram líderes nos movimentos sindicais, sociais e mesmo nas ONGs e, diretamente por meio de parlamentares na Campanha contra a ALCA, no plebiscito popular e na iniciativa de propor um plebiscito oficial ao final das negociações ${ }^{99}$. Assim, apesar das preocupações com a questão da autonomia, quando o governo federal lança em 2006 a iniciativa de uma Cúpula Social do Mercosul, seguida pela criação do PMSP (negociado como Conselho Mercosul Social e Participativo) a maior parte das organizações da sociedade civil que vinham das mobilizações contra a ALCA decide participar, com exceção dos movimentos da CLOC-Vía Campesina.

Embora a participação nos canais oficiais do Mercosul já figurasse entre as estratégias do movimentos sindical nos anos noventa, junto com a ação coletiva transnacional de caráter mais contestatório, a partir de 2003 e, principalmente após o fim das negociações hemisféricas, a participação passa a ser uma estratégia central para a maioria das organizações da sociedade civil mobilizadas no período prévio. Mas além disso, como mostrado anteriormente, a participação nestes canais oficiais coexistiu de 2006 a 2010 com a organização de atividades paralelas e autônomas por

\footnotetext{
98 Texto datado de 1992, do então Secretário de Relações Internacionais do PT e Assessor Especial da Presidência da República desde o início do governo Lula, Marco Aurelio Garcia, aponta neste sentido: $O$ papel das forças de esquerda do continente não é o de rejeitarem princípio a tese da integração, mas situá-la dentro de novos parâmetros, distintos daqueles propostos pelo neoliberalismo. Para tanto é fundamental resgatar algumas idéias que devem estar na base de qualquer política de integração: respeito à autodeterminação e à soberania nacional; garantia de um papel para o Estado (democrático e socialmente controlado) nas políticas de desenvolvimento industrial e econômico; prioridade para políticas de crescimento econômico com redistribuição de renda; definição e implementação de programas de complementariedade econômica articulando distintos países do continente; preservação e, sobretudo, ampliação das conquistas democráticas das classes trabalhadoras, permitindo que estas tenham um papel decisivo nas políticas econômicas e sociais nas esferas nacional e multinacional. Esta preocupação deve se refletir particularmente no que se refere às leis e dispositivos de proteção ao trabalho conquistados em décadas de luta e que hoje se encontram ameaçados em todo o continente; e políticas de preservação ambiental comuns. (Garcia, 1992)

99 Iniciativa do então deputado federal Aloizio Mercadante. Ver, por exemplo, O plebiscito sobre a Alca, Aloizio Mercadante. Folha de São Paulo, 18 de marco de 2001.
} 
organizações integrantes da regional sul da ASC, sugerindo que as estratégias de mobilização outsider e participação insider podem ser complementares.

Cabe ressaltar que, mesmo que houvesse a percepção de "abertura das estruturas de oportunidades políticas" nacionais e regionais por parte das organizações da sociedade civil, ainda não estava claro qual seria o caminho trilhado pelo Mercosul: as negociações de um acordo com a UE ainda estavam em andamento, bem como as negociações multilaterais da Rodada Doha da OMC, de modo que a abertura destes espaços no Mercosul poderiam ser passos importantes para se avançar nas demandas de transparência e participação em outras negociações. É também por volta de 2003 que surgem referências entre organizações da sociedade civil à ideia de pensar a política externa como uma política pública, cuja formulação, portanto, poderia/deveria estar sujeita à "democratização", inclusive por meio de uma instância nos moldes dos conselhos gestores existentes em outras áreas de política pública ${ }^{100}$. Neste caso, mais do que mobilizar normas internacionais via a externalização de reivindicações, a abertura de espaços participativos no Mercosul colocava para as organizações da sociedade civil a oportunidade de pressionar por novas normas no âmbito de acordos regionais, particularmente com relação à transparência e à consulta em negociações comerciais e, no limite, à formulação da política externa de forma mais ampla.

Ao longo do caso do Mercosul, fica claro que participar dos canais institucionais é em última instância um elemento de legitimação das iniciativas governamentais. O que não significa plena concordância com as políticas do governo, mas compartilhamento de um projeto político identificado como progressista ou democrático-popular, que ganha sentido

100 Entrevista com Graciela Rodríguez, Instituto Equit/Rebrip, relata estas discussões no âmbito da Rebrip. Renuiões internas sobre este tema também foram realizadas na secretaria de relações internacionais do PT. 
em contraposição ao projeto liberal que orientou a integração regional nos anos noventa e tem como um de seus elementos simbólicos a ideia de "participação social".

Assim, parece correto afirmar que mesmo diante de estruturas de oportunidades políticas permeáveis às demandas de organizações da sociedade civil, a atuação transnacional poderia sustentar-se via instâncias participativas que poderiam constituir novas práticas e atores. A mudança dos cenários doméstico e regional não levou imediatamente à desmobilização porque a abertura de canais de diálogo relativos à integração regional foram percebidos como uma oportunidade para o avanço de mecanismos de consulta e transparência em negociações internacionais. Desse modo, durante os cinco primeiros anos depois do fim da ALCA, é possível dizer que apesar de divisões e diferentes estratégias entre os movimentos, a atuação no âmbito do Mercosul tornou-se mais ampla e diversa do que tivera sido até então. Contudo, este processo mostrou limites no Mercosul, tanto pela fragilidade dos canais participativos - nacional e regional -, quanto pela dificuldade de aprofundamento da integração no bloco.

\section{Participação regional e estrutura institucional do Mercosul}

Embora a criação de um novo espaço de diálogo no âmbito do Mercosul pudesse potencialmente sustentar as articulações das organizações da sociedade civil no plano regional, este potencial se verificou por um período limitado. Ainda que não seja possível estabelecer critérios claros de corte, já que no limite as organizações continuam assistindo às Cúpulas, todas as entrevistas realizadas apontam os limites deste modelo nos últimos anos, já que, apesar da progressiva institucionalização, praticamente não há interlocução formal com as instâncias de tomada de decisão, não há mecanismos para o seguimento do que foi decidido e, 
devido à estrutura intergovernamental do bloco, sua realização é inteiramente dependente da PPT em turno, o que implica em concepções diferenciadas sobre a relação entre Estado e sociedade civil em cada país. Este é um limite claro às articulações entre organizações da sociedade civil, na medida em graus diferenciados de autonomia têm gerado atrito entre as próprias organizações.

Além disso, vale mencionar que, apesar da criação de novas instâncias no interior do Mercosul, o processo de tomada de decisão no bloco continua concentrado em poucos órgãos, conforme o desenho institucionalizado no Protocolo de Ouro Preto. O Mercosul caracteriza-se por uma estrutura institucional inteiramente intergovernamental, centrada nos poderes Executivos dos Estados parte, sobretudo nos ministérios de relações exteriores e economia. Isso significa dizer que 1) todas as normativas precisam ser aprovadas por consenso; 2) os órgãos com poder decisório são formados pelos Ministros do Exterior e da Economia (CMC) ou por representantes destes ministérios e dos Bancos Centrais (GMC e, particularmente no caso da CCM por representantes da área de comércio exterior); e 3) dependendo do tipo de norma, devem ser internalizadas no ordenamento jurídico de cada membro, de acordo com os procedimentos constitucionais de cada Estado ${ }^{101}$. Apesar da existência de uma normativa que tenta coordenar a entrada em vigor das normas simultaneamente em todos os Estados parte, na prática isso não ocorre. O grau de vigência das normas do MERCOSUL nos Estados Partes é heterogêneo e, além disso, é praticamente impossível ter acesso a informações sobre o estado da incorporação de normas nos países, dado que a informação é de caráter

\footnotetext{
101 Um estudo de um grupo de pesquisadores do Instituto de Relações Internacionais da USP e da Universidade Federal de Pernambuco (Ventura, Onuki, Fernandes et al., 2012) sobre a internalização de normas no Mercosul aponta que, considerando um conjunto de 1382 resoluções do GMC de 1991 a 2011, 55\% exigia a incorporação no ordenamento jurídico brasileiro. Esta internalização ocorre por três procedimentos: modo padrão (aprovação pelo Parlamento, ratificação e promulgação pelo Executivo); decreto presidencial ou publicação direta por Ministérios ou outros órgãos do poder Executivo. O estudo aponta ainda que cerca de $90 \%$ das normas que exigem incorporação ao ordenamento nacional dispensam o procedimento padrão e dependem exclusivamente do poder executivo (Ventura, Onuki, Fernandes et al., 2012:18).
} 
reservado. Uma vez incorporada, a publicação no Diário Oficial da União se dá de forma pulverizada, com outra nomenclatura e numeração. Isso significa que é praticamente impossível saber ser as normativas que constam como aprovadas no site do Mercosul estão de fato em vigor. (Ventura, Onuki, Fernandes et al., 2012). Segundo um dos entrevistados, esta falta generalizada de informações sobre a internalização e a multiplicação de espaços de negociação, muitas vezes sobre o mesmo tema, faz com que muitas questões já discutidas no passado voltem à tona. Um entrevistado resume esta situação numa frase: as coisas que estão aprovadas no Mercosul são avançadíssimas, agora qual delas funciona?

\section{Participação institucionalizada e política externa}

Em um trabalho de sistematização de uma série de casos de participação de organizações da sociedade civil em instâncias institucionais, Dagnino trabalha com a hipótese de que os conflitos entre representantes da sociedade civil e do Estado nestes espaços participativos têm como elemento central a partilha efetiva do poder, e tendem a ser maior ou menor dependendo do compartilhamento de um projeto político participativo e democratizante (2002:282). No caso do PMSP, mesmo se consideradas as restrições constitucionais, as resistência para o "compartilhamento efetivo do poder" na área de política externa colocam limites para o processo.

Aqui chegamos a um ponto não explorado até o momento, mas que problematiza justamente os limites de se pensar em mecanismos participativos na área de política externa e a dificuldade de transposição do instrumental analítico da ciência política para um tema da área internacional. 
A separação epistemológica entre o âmbito doméstico e o internacional é uma característica da construção das Relações Internacionais como campo específico de conhecimento. Não cabe aqui reproduzir a narrativa oficial de construção da disciplina, mas vale situar que um dos produtos históricos da modernidade, o sistema de Estados nacionais territoriais soberanos é assumido como um dado por todas as abordagens teóricas mainstream. Esta naturalização não ocorre apenas nas RI, mas também está presente no restante das ciências sociais. Ao traçar um paralelo entre os processos de construção do Estado-nação e do arcabouço teórico e metodológico das ciências sociais, Wimmer e Glick-Schiller (2002) apontam justamente a redução do foco analítico às fronteiras do Estadonação e a naturalização da dimensão nacional nas ciências sociais empiricamente orientadas.

Uma das implicações analíticas desta premissa é a impossibilidade de se pensar a atuação de organizações da sociedade civil como atores plenos no sistema internacional. Não à toa, as perspectivas teóricas apresentadas até aqui não desafiam esta premissa e buscam entender a ação transnacional de organizações da sociedade civil em relação às formas de interação e influência sobre Estados (e Ols formadas por Estados). A princípio, a existência de mecanismos participativos no âmbito da formulação de política externa não seria incompatível com esta visão. Contudo, o referencial analítico desenvolvido na ciência política sobre instituições participativas não é facilmente transposto para o âmbito da diplomacia. A concepção tradicional do ambiente internacional como anárquico e marcado em última instância pelas preocupações em torno da segurança sustenta a ideia da diplomacia como uma política peculiar, que justificaria sua separação de outras áreas de elaboração política, como educação, saúde, assistência social, entre várias outras, consideradas públicas, que passam por experiências de participação e controle social. 
Contudo, se não aceitarmos esta premissa, a questão passa a ser justamente entender como novas práticas se constituem nos espaços políticos entre as fronteiras dos planos doméstico e internacional As amplas mobilizações sociais em torno de temas e instituições internacionais no final da década de noventa refletem críticas ao processo de globalização e seus efeitos assimétricos. Segundo Lima, a simultaneidade da redemocratização e da abertura econômica no Brasil teria modificado a natureza da política externa, que passariam a ter que negociar interesses setoriais, inserindo-se diretamente no conflito distributivo interno (2000:295). Milani e Pinheiro adotam um argumento semelhante, ao afirmar que nas últimas décadas, a combinação de redemocratização e programas estruturais de abertura econômica teriam gerado um crescimento no número de atores envolvidos com temas de política externa com interesses diversificados (2013:17). Por outro lado, num movimento complementar, outras áreas de formulação política estariam passando por um processo de internacionalização (por exemplo, via a abertura de escritórios internacionais da Embrapa em Gana e da Fiocruz em Moçambique), dando espaço para a atuação internacional de outros ministérios e agências de governo, bem como para a influência de atores não-estatais (2013:25). Contestando a premissa realista da política externa como um campo distante do cotidiano dos cidadãos e apontando a natureza transversal de questões na área, os autores afirmam que, apesar das desigualdades e diferenças que as conformam, as estruturas das ordens doméstica e internacional deixam em aberto - e de modo nem sempre previsível - vários espaços para a ação política, inclusive de atores não-estatais. (2013:18)

Assim, afirmam:

(...) ao assumirmos a política externa como uma política pública, estamos trazendo a política externa para o terreno da politics, ou seja, reconhecendo que sua formulação e implementação se inserem na dinâmica das escolhas de governo que, por sua vez, resultam de coalizões, barganhas, disputas, acordos entre representantes de 
interesses diversos, que expressam, enfim, a própria dinâmica da política. (Milani e Pinheiro, 2013: 24)

Embora esta agenda de pesquisa esteja ainda em estágios iniciais, este trabalho compartilha desta interpretação, ao mostrar que a participação de organizações da sociedade civil no Mercosul, principalmente via o Programa Mercosul Social e Participativo no âmbito da SG/PR e do MRE, apesar de todas as suas limitações, constitui um caso inovador de institucionalização de participação social na área de formulação de política externa.

\section{Mercosul e o regionalismo sul-americano}

Se vistos em conjunto, os limites institucionais, nacionais e regionais, para uma participação efetiva e a desarticulação de iniciativas autônomas a partir de 2010 apontam certo desânimo das organizações da sociedade civil com relação ao bloco. Ao mesmo tempo, novas iniciativas de mobilização extrainstitucional e demanda de espaços de consulta (com a formação de novas redes transnacionais em torno do tema ambiental e dos direitos dos povos indígenas no contexto dos megaprojetos de infraestrutura na Unasul, por exemplo) apontam a persistência dos repertórios de confronto e participação. Desse modo, este retrocesso de expectativas no Mercosul reflete a própria dificuldade de se avançar e aprofundar o processo de integração regional.

A coexistência de diferentes iniciativas regionais na América do Sul (e Latina) tem suscitado debates entre especialistas sobre a fragmentação ou a complementariedade destes processos na região. Malamud e Gardini (2012) argumentam que a presença de projetos regionalistas segmentados e sobrepostos sinaliza a exaustação do potencial de integração no sub-continente, dada a falta de aprofundamento das iniciativas existentes e o retrocesso rumo a acordos de cooperação. 
Embora reconheçam que um paralelo com a experiência europeia seja problemático, ainda sim argumentam que a Europa pode ser uma referência para comparação, já que tem sido tomada como tal por analistas e tomadores de decisão (2012:120). Por outro lado, Lima (2013:178) critica a adoção do que considera um modelo idealizado e teleológico de integração regional, à semelhança do processo europeu, defendendo que a tarefa analítica e prática seria justamente estabelecer novas bases conceituais do regionalismo sul-americano. Ao propor que distingamos entre os processos de integração (formação de um espaço econômico integrado e, em alguns casos, delegação de soberania) e os de regionalismo (cooperação em diversas áreas, dinâmica intergovernamental, objetivos menos ambiciosos), a autora sugere que ajustemos nossas lentes conceituais na América do Sul ao segundo tipo. Nesta linha seria necessário entender a sobreposição entre iniciativas regionais a partir da própria experiência histórica e realidade sulamericanas. No caso específico, teríamos na última década o desenvolvimento de um modelo capaz de acomodar a diversidade de modelos econômicos de integração regional (Mercosul, Alba, Aliança do Pacífico) dentro de iniciativas regionais políticas, como a Unasul.

Embora concordemos com o argumento de Lima (2013) sobre a necessidade de novas bases analíticas para os processos regionais na América do Sul, as entrevistas apontam a percepção de que a ausência de avanços significativos na dimensão econômica da integração enfraquecem as próprias conquistas (reconhecidas) no plano político, já que a recorrência de respostas nacionais aos problemas econômicos tende a gerar conflitos entre os membros do Mercosul (como aliás acontece desde o início) e minar o projeto regional. Ainda que grande parte das organizações entrevistadas se identifique como parte de um "campo progressista" e valorize uma proposta pós-liberal ou contrahegemônica de integração, o estancamento do Mercosul, o avanço de outras agendas no âmbito da Unasul (com o interesse de grandes 
empresas brasileiras na expansão de negócios na região), aliado aos frágeis mecanismos de participação dificultam o engajamento sustentado em torno do regionalismo.

Assim, ainda que inicialmente após o adiamento das negociações da ALCA tenha havido certo otimismo com relação ao Mercosul e uma ampliação significativa no número de organizações da sociedade civil engajadas nas questões regionais, com novos canais de participação, este processo tem perdido fôlego frente às dificuldades de se aprofundar a integração regional. 


\section{Considerações finais}

Conforme considerado no início, nas últimas décadas, o campo das relações internacionais testemunhou um enorme crescimento de estudos e pesquisas sobre a atuação transnacional de atores não-estatais. Uma parte significativa destes trabalhos abordou o tema a partir da ideia de uma sociedade civil de caráter internacional ou global. Diante da perspectiva homogeneizante e normativa contida em muitas destas contribuições, um campo profícuo de análise destes processos tem se desenvolvido em torno dos estudos do novo transnacionalismo.

Argumentamos que as contribuições da sociologia, particularmente dos estudos de movimentos sociais, para esta agenda nas RI traz ganhos analíticos significativos, na medida em que lança luz sobre os variados processos em curso, sobre as dinâmicas de conflito entre os atores sociais e sobre a conexão entre os planos doméstico e internacional para a compreensão da emergência do ativismo transnacional. Este movimento acontece sobretudo com a transposição do conceito de estruturas de oportunidades políticas para o plano internacional (regimes, Ols e normas internacionais). Contudo, consideramos também que, dada a influência da abordagem do processo político, que ilumina os repertórios contenciosos de movimentos sociais com relação aos Estados, as contribuições teóricas tendem a privilegiar justamente os tradicionais repertórios de confronto político, ainda que uma série de estudos de caso apontem a coexistência de mobilizações extra-institucionais com estratégias de participação em canais oficiais de diálogo.

Para contribuir com esta discussão, escolhemos estudar a atuação de organizações da sociedade civil brasileira no Mercosul, particularmente no cenário posterior ao adiamento das negociações hemisféricas da ALCA, mas com atenção ao histórico desta atuação, de modo a entender como 
diferentes estruturas de oportunidades políticas geraram mudanças na atuação destas organizações, que eventualmente poderiam levar à constituição de novos temas. Revisando a literatura da área, trabalhamos com a hipótese de que, embora a abertura simultânea dos cenários políticos institucionais nacional e internacional tenda a gerar diminuição do ativismo transnacional, a existência de canais de participação podem gerar uma dinâmica sustentada de atuação, como se verifica no Mercosul, para além das ações episódicas em torno de campanhas transnacionais. A recente diminuição no ritmo de atuação de organizações da sociedade civil não seria reflexo da "abertura" de estruturas de oportunidades políticas, mas reflexo das dinâmicas intergovernamentais do bloco, das dificuldades de aprofundamento da integração e da coexistência com outras iniciativas regionais.

Por meio da caracterização do contexto político e da percepção das organizações da sociedade civil sobre este cenário, vimos que, embora o fim do projeto da ALCA tenha retirado a ameaça que mobilizou a formação de uma ampla coalizão transnacional e tenha desarticulado parcialmente este movimento prévio, a criação de novos espaços de participação contou com certo otimismo por parte das organizações da sociedade civil, na medida em que foi articulada por quadros prévios dos movimentos, que passavam naquele momento a ocupar posições no governo federal. Desse modo, estes novos canais de diálogo, ainda que incipientes, eram vistos como forma de dar início a novas práticas nas negociações internacionais, rumo a maior transparência e consulta aos diversos setores da sociedade. Somado a isto, a preocupação com a autonomia das organizações da sociedade civil frente aos governos motivou a continuidade de atividades independentes sobre o tema da integração, em torno das chamadas cúpulas dos povos. A manutenção destas duas ações - participação e mobilização extrainstitucional - manteve-se por cerca de cinco anos (entre 2005 e 2010). 
Para além da própria abertura do processo de integração para um maior número de organizações da sociedade civil, o Programa Mercosul Social e Participativo, apesar das dificuldades, constitui-se como uma experiência única de participação social na área de formulação de política externa. Com a implementação recente do Fórum de Participação Cidadã da Unasul, o PMSP passou a incluir também temas relativos à Unasul em sua pauta. Além disso, esta experiência participativa tem alimentado demandas pelo aprofundamento de controles democráticos na área de formulação de política externa, estimulando o debate em curso sobre a criação de uma instância de participação e consulta (nos moldes dos conselhos, ainda que não com atribuições deliberativas) não apenas na área de integração, mas da política externa como um todo, reforçando o entendimento de seu caráter como uma política pública. 


\section{Anexos}

1.Mobilização social e participação institucionalizada na atuação das organizações da sociedade civil no Mercosul

\begin{tabular}{|c|c|c|c|}
\hline Ano & $\begin{array}{l}\text { Negociações } \\
\text { diplomáticas }\end{array}$ & $\begin{array}{l}\text { Estratégias } \\
\text { extrainstitucionais de } \\
\text { mobilização/repertórios } \\
\text { de confronto }\end{array}$ & $\begin{array}{l}\text { Participação em canais } \\
\text { institucionais/repertórios } \\
\text { de interação }\end{array}$ \\
\hline 1990 & $\begin{array}{l}\text { Lançamento da } \\
\text { Iniciativa para as } \\
\text { Américas }\end{array}$ & & \\
\hline 1991 & Tratado de Assunção & $\begin{array}{l}\text { Pronunciamento da } \\
\text { CCSCS sobre integração }\end{array}$ & $\begin{array}{l}\text { Criação do SGT-11: } \\
\text { movimento sindical } \\
\text { participa como observador }\end{array}$ \\
\hline 1994 & $\begin{array}{l}\text { Protocolo de Ouro } \\
\text { Preto }\end{array}$ & & $\begin{array}{l}\text { Institucionalização da } \\
\text { participação sindical no } \\
\text { SGT-11 }\end{array}$ \\
\hline 1995 & & $\begin{array}{l}\text { Ato do } 1^{\circ} \text {. de maio na } \\
\text { fronteira }\end{array}$ & \\
\hline 1996 & & $\begin{array}{l}\text { Comissões sindicais } \\
\text { setoriais no âmbito da } \\
\text { CCSCS } \\
\text { Manifestação sindical } \\
\text { durante a Cúpula de } \\
\text { Presidentes do Mercosul } \\
\text { em Fortaleza }\end{array}$ & $\begin{array}{l}\text { Implementação do FCES, } \\
\text { com intensa participação } \\
\text { sindical }\end{array}$ \\
\hline 1997 & $\begin{array}{l}\text { Conferência Ministerial } \\
\text { da ALCA em BH }\end{array}$ & $\begin{array}{l}\text { Lançamento da iniciativa de } \\
\text { uma aliança hemisférica } \\
\text { em BH }\end{array}$ & \\
\hline 1998 & $\begin{array}{l}\text { III Cúpula das } \\
\text { Américas em } \\
\text { Santiago. Lançamento } \\
\text { das negociaçôes } \\
\text { oficiais da ALCA }\end{array}$ & $\begin{array}{l}\text { Nasce ideia da Rebrip em } \\
\text { atividade paralela durante a } \\
\text { Cúpula de Presidentes do } \\
\text { Mercosul no Rio. }\end{array}$ & $\begin{array}{l}\text { Declaração Sócio-Laboral } \\
\text { e Comissão Sócio-Laboral } \\
\text { do Mercosul }\end{array}$ \\
\hline
\end{tabular}




\section{Ano Negociações Estratégias diplomáticas \\ extrainstitucionais de mobilização /repertórios de confronto}

1999 Crise no Mercosul Pré-negociaçães para acordo UE-Mercosul

2000 I Reunião de Presidentes da América do Sul. Lançamento da IIRSA

2001 Cúpula das América em Quebec.

2002 II Reunião de Presidentes da América do Sul.
Ato $1^{\circ}$. maio na fronteira

Protestos contra a OMC em Seatlle

Manifestação sindical Presidentes do Mercosul em Florianópolis

II Cúpula dos Povos das Américas em Quebec. ASC e movimentos antiglobalização

\section{FSM Porto Alegre}

Lançamento da Campanha Continental contra a ALCA no FSM Porto Alegre durante a Cúpula de

2003 Conferência Ministerial em Miami. Mudança na posição brasileira. ALCA light

Consenso de Buenos Aires, assinado pelos Presidentes Lula e Kirchner pelo fortalecimento da relação bilateral e relançamento do Mercosul

2004 Comunidade SulAmericana de Nações

Mercosul: objetivos 2004-2006

Criação do Focem

2005 Cúpula das Américas em Mar del Plata adiamento sine die

III Cúpula dos Povos das Américas, em Mar del Plata
Participação em canais institucionais/repertórios de interação
Inclusão de representantes de organizações da sociedade civil na delegação oficial do Brasil nas negociações da ALCA

Encontros com o Mercosul, por iniciativa da Secretaria Geral, em capitais, para diálogo com empresários, sindicatos, movimentos sociais
Encontro por um Mercosul Social e Produtivo, durante Cúpula de 


\begin{tabular}{|clll|}
\hline Ano & $\begin{array}{l}\text { das negociações } \\
\text { Negociações } \\
\text { diplomáticas }\end{array}$ & $\begin{array}{l}\text { Estratégias } \\
\text { extrainstitucionais de } \\
\text { mobilização /repertórios } \\
\text { de confronto }\end{array}$ & $\begin{array}{l}\text { Presidentes em Córdoba } \\
\text { Participação em canais } \\
\text { institucionais/repertórios } \\
\text { de interação }\end{array}$ \\
2006 & $\begin{array}{l}\text { Início das Cúpulas dos } \\
\text { Povos do Sul, paralelas às } \\
\text { cúpulas de presidentes do } \\
\text { Mercosul }\end{array}$ & $\begin{array}{l}\text { Início das Cúpulas Sociais } \\
\text { do Mercosul }\end{array}$ \\
& $\begin{array}{l}\text { Cúpula pela Integração do } \\
\text { Povos - Cochabamba }\end{array}$ & \\
& & $\begin{array}{l}\text { Criação do Programa } \\
\text { Mercosul Social e } \\
\text { Participativo, por iniciativa } \\
\text { da Secretaria Geral e co- } \\
\text { cordenado pelo MRE. }\end{array}$ \\
\hline & &
\end{tabular}


2. Lista de organizações atuantes no Programa Mercosul Social e Participativo

1. ABIA - Associação Brasileira Interdisciplinar de AIDS

2. Ação Educativa

3. ABGLT- Associação Brasileira de Gays, Lésbicas e Transgêneros

4. Alampyme - Associação Latino-Americana de Pequenas e Médias Empresas

5. Campanha Nacional pelo Direito à Educação

6. CDHIC - Centro de Direitos Humanos e Cidadania do Imigrante

7. Cebrapaz

8. CGTB - Central Geral dos Trabalhadores do Brasil

9. Cives - Associação Brasileira de Empresários pela Cidadania

10. CMB - Confederação das Mulheres do Brasil

11. Conectas Direitos Humanos

12. Conen - Coordenação Nacional de Entidades Negras

13. Contag - Confederação Nacional dos Trabalhadores na Agricultura

14. CSA - Confederação Sindical das Américas

15. CTB - Central dos Trabalhadores do Brasil

16. CUFA - Central Única das Favelas

17. CUT - Central Única dos Trabalhadores

18. DIEESE/Aliança Social Continental

19. FASE/Rebrip

20. FBES - Fórum Brasileiro de Economia Solidária

21. FBOMS - Fórum Brasileiro de ONGs e Movimentos Sociais para o Meio Ambiente e o Desenvolvimento

22. FDIM - Federação Democrática Internacional de Mulheres

23. Fetraf -

24. FoMerco - Fórum Universitário do Mercosul

25. Força Sindical

26. Geledes - Instituto da Mulher Negra

27. Geomercosul Juvenil

28. Ibase - Instituto Brasileiro de Análises Sociais e Econômicas

29. IDDH - Instituto de Desenvolvimento e de Direitos Humanos

30. IDECRI - Instituto de Desenvolvimento da Cooperação e Relações Internacionais

31. INESC - Instituto de Estudos Socioeconômicos

32. Instituto Equit/ Aliança Social Continental

33. Instituto Observatório Social

34. Instituto Paulo Freire

35. Instituto Pólis

36. Intervozes

37. MMM - Marcha Mundial de Mulheres

38. Movimento Nacional dos Direitos Humanos

39. Programa Mercosul Social e Solidário

40. REBRIP - Rede Brasileira pela Integração dos Povos

41. Serviço Pastoral do Migrante-CAMI

42. UGT - União Geral dos Trabalhadores 


\section{Lista de entrevistas}

Fátima Mello, membro do núcleo de justiça ambiental e direitos da FASE integrante da Rebrip

Filomena Siqueira, assessora de Relações Internacionais da Ação Educativa

Giorgio Romano Schutte, ex-assessor especial da Secretária Geral da Presidência da República entre 2004 e 2006

José Renato Vieira Martins, ex-assessor especial da Secretária Geral da Presidência da República entre 2006 e 2010

Maria Silvia Portela de Castro, consultora e ex-assessora da Secretaria de Relações Internacionais da Central Única dos Trabalhadores

Moema Miranda, diretora do Ibase

Paola Estrada, assessora da ALBA movimentos

Rafael Freire Neto, integrante do Secretariado da Confederação Sindical das Américas e ex-Secretário de Relações Internacionais da Central Única dos Trabalhadores

Salete Valesa, ex-diretora do Instituto Paulo Freire e atual representante da Flacso no Brasil

Tania Rocio, Coordenadora Executiva do Centro de Direitos Humanos e Cidadania do Imigrante 


\section{Referências bibliográficas}

ABERS, Rebecca (1996). From Ideas to Practice: The Partido dos Trabalhadores and Participatory Governance in Brazil. Latin American Perspectives, 91, Vol. 23 No. 4, 1996.

ABERS, Rebecca (1998). From clientelism to cooperation: local government, participatory policy, and civic organizing in Porto Alegre, Brazil. Politcs and Society, vol. 26, n.4, december.

ABERS, Rebecca; VON BÜLLOW, Marisa (2011). Movimentos sociais na teoria e na prática: como estudar o ativismo através da fronteira entre estado e sociedade? Sociologias, vol.13 no.28 Porto Alegre.

ABERS, Rebecca; SERAFIM, Lizandra; TATAGIBA, Luciana (2014). Repertórios de interação estado-sociedade em um estado heterogêneo: a experiência na Era Lula. DADOS - Revista de Ciências Sociais, vol.57 no.2 Rio de Janeiro.

ALEMANY, Cecilia; LEANDRO, Beatriz (2006). Análisis y propuestas para la participación ciudadana en el MERCOSUR. Montevideo: Fundación Friedrich Ebert, 2006.

ALIANÇA SOCIAL CONTINENTAL. Alternativa para las Américas, 2002.

ALONSO, Angela (2009). As teorias dos movimentos sociais: um balanço do debate. Lua Nova. São Paulo, 76: pp. 49-86

ALVAREZ, Marcelo (2011). Los 20 años del Mercosur: una integración a dos velocidades. CEPAL - Serie comercio internacional, no. 108. 
AVRITZER, Leornado (2000). Teoria democrática e deliberação pública. Lua Nova, no. 49.

AVRITZER, Leonardo (2011). A qualidade da democracia e a questão da efetividade da participação: mapeando o debate. In: Pires, R. R. (org.) Efetividade das instituições participativas no Brasil: estratégias de avaliação. Brasília: Ipea.

AVRITZER, Leonardo (2012). Sociedade civil e Estado no Brasil: da autonomia à interdependência política. Opinião Pública, Campinas, vol. 18, no 2, novembro, p. 383-398

AVRITZER, Leonardo; COSTA, Sergio (2004). Teoria Crítica, Democracia e Esfera Pública: Concepções e Usos na América Latina. DADOS - Revista de Ciências Sociais, Rio de Janeiro, Vol. 47, no 4, pp. 703 a 728.

BARALDI, Camila (2014). Migrações internacionais, direitos humanos e cidadania sul-americana: o prisma do Brasil e da integração sul-americana. Tese de Doutorado. Instituto de Relações Internacionais, Universidade de São Paulo

BARROS, Pedro S.; RAMOS, Felippe S. (2013). O Novo mapara da integração latino-americana: balance e perspectiva da estratégia da política externa brasileira para a região. Revista IMEA UNILA, Vol. 1, n. 2, 2013

BARTELSON, Jens (2006). Making sense of Global Civil Society. European Journal of International Relations Vol. 12 (3), 371-395

BARTELSON, Jens (2009). Is There a Global Society? In: Forum on Global Society. International Political Sociology Vol.3 (1), 109-136

BATTAGLINO, Jorge (2009). O Brasil e a criação do Conselho de Defesa Sul-Americano. Revista Nueva Sociedad, dez/2009 
BEACH, Derek e PEDERSEN, Rasmus (2012). Process-tracing methods: foundations and guidelines. University of Michigan Press.

BERRÓN, Gonzalo (2007). Identidades e estratégias sociais na arena transnacional. O caso do movimento social contra o livre comércio nas Américas. Tese de doutorado, Departamento de Ciência Política, Universidade de São Paulo.

BERRÓN, Gonzalo (2013). Viejos y nuevos dilemas para la participación social en los procesos de integración sudamericanos. Cadernos Prolam/USP 12 (23), pp. 42-55.

BORBA, Sandra (2012). Desafios y Oportunidades de la Unión de Naciones Suramericanas (Unasur). Documentos CRIES, nO 18, 2012.

BORRAS Jr, Saturnino (2008). "La Via Campesina and its Global Campaign for Agrarian Reform". In: Borras, Edelman e Kay. Transnational agrarian movements: origins and politics, campaigns and impacts. Wiley-Blackell.

CAETANO, Gerardo; VÁZQUEZ, Mariana; VENTURA, Deisy (2008). Reforma institucional del Mercosur: analisis de un reto. Documento de trabalho CEFIR.

CAMARGO, Sonia de. (2006). Mercosul: crise de crescimento ou crise terminal? Lua Nova, São Paulo, n. 68, p. 57-90.

CARLOS, Euzeneia (2011). Movimentos sociais: revisitando a participação e a institucionalização. Lua Nova, São Paulo, 84: 353-364,

CARVALHO, Priscila (2011). Ação coletiva transnacional e Mercosul: organizações da sociedade civil do Brasil e do Paraguai na construção da Reunião Especializada sobre Agricultura Familiar (REAF). Dissertação de Mestrado, Instituto de Ciência Política, Universidade de Brasília. 
CEPAL (1994). Open regionalism in Latin America and the Caribbean economic integration as a contribution to changing production patterns with social equity. Santiago, Chile.

CEPAL (2014). Panorama de la inserción internacional de América Latina y Caribe. Relatório anual da Divisão de Comércio Internacional e Integração da CEPAL, Santiago do Chile.

CERVO, Amado; BUENO, Clodoaldo (2008). Historia da Política Exterior do Brasil. Brasilia: editora UnB

CHASE-DUNN, Christopher e GILLS, Bary (2005). Waves of globalization and resistance in the capitalist world-system: social movements and critical global studies. In: Appelbaum, Richard e Robinson, William. Critical Globalization Studies. Oxon/NY: Routledge.

CHECKEL, Jeffrey (2005). International Institutions and Socialization in Europe: Introduction and Framework. International Organization, Vol. 59, No. 4, International Institutions and Socialization in Europe, pp. 801-826

CLARK, Ann Marie; FRIEDMAN, Elisabeth J.; HOCHSTETLER, Kathryn (1998). The Sovereign Limits of Global Civil Society: A Comparison of NGO Participation in UN World Conferences on the Environment, Human Rights, and Women. World Politics, Vol. 51, No. 1 pp. 1-35

COLAS, Alejandro (2002). International Civil Society: Social Movements in World Politics. Oxford: Polity.

COX, Robert (1999). Civil society at the turn of the millennium: prospects for an alternative world order. Review of International Studies 25, pp. 3-28.

COX, Robert (2007). The international in evolution. Millennium: Journal of International Relations 35 
CUT (1996). Textos para debate internacional: estratégias sindicais para a promoção da dimensão social do Mercosul.

CUT (1997). Resoluções do $6^{\circ}$. Congresso Nacional da CUT.

CUT (2000). Integração regional, mercado de trabalho e ação sindical: o caso Mercosul. CSN, SRI-CUT e DESEP

DAGNINO, Evelina (2002). sociedade civil e espaços públicos no Brasil. São Paulo: Paz e Terra

DAGNINO, Evelina (2004). Sociedade civil, participação e cidadania: de que estamos falando. In Daniel Mato (coord.), Políticas de ciudadanía y sociedad civil en tiempos de globalización. Caracas: FACES, Universidad Central de Venezuela.

DELLA PORTA, Donatella e TARROW, Sidney (2005). "Transnational processes and social activism: an introduction. In: Della Porta e Tarrow, Transnational protest and global activism. Rowman \& Littlefield Publishers.

DELLA PORTA, Donatella; DIANI, Mario (2006). Social Movements: an introduction. Blackwell publishing.

DELLA PORTA, Donatella (2007). The Global Justice Movement: CrossNational and Transnational perspectivas. Paradigm Publishers.

ESCOBAR, Arturo (2008). Beyond the Third World: imperial globality, global coloniality and anti-globalisation social movements. Third World Quarterly, vol 25, No 1, pp 207-230.

FRIEDMAN, Elisabeth J.; HOCHSTETLER, Kathryn; CLARK, Ann Marie (2001). Sovereign Limits and Regional Opportunities for Global Civil Society in Latin América. Latin American Research Review, Vol. 36, No. 3, pp. 7-35. 
GARCIA, Marco Aurelio (1992). O PT e a nova ordem. Revista Teoria e Debate, no. 18, maio/junho/julho.

GILL, Stephen (2000). Toward a Postmodern Prince? The battle in Seattle as a moment in the new politics of globalisation. Millennium: Journal of International Relations v.29, n.1.

HERZ, Monica; HOFFMAN, Andrea (2004). Integração regional. In:

Organizações Internacionais: histórias e práticas. Rio de Janeiro: Elsevier.

HETTNE, Björn; SÖDERBAUM, Frederik (2008) "The future of regionalism: old divides, new frontiers." In: COOPER; HUGHES; LOMBAERDE (eds.), Regionalisation and Global Governance - The taming of globalisation?; New York, p. 61-79.

HILL, Christopher. What is to be done? Foreign policy as a site for political action. Conferência na London School of Economics and Political Science, novembro de 2002. Disponível em:

http://www.lse.ac.uk/internationalRelations/pdf/CJHwhatistobedone.pdf

HIRST, Mônica; PINHEIRO, Letícia (1995). A Política Externa do Brasil em dois tempos. Rev. Bras. Polít. Int. 38 (1): 5-23

HIRST, Mônica (2006). Los desafíos de la política sudamericana de Brasil. Nueva Sociedad, Buenos Aires, v. 205, p. 131-140, set/out.

HOCHSTETLER, Kathryn (2003). Mercosur, ciudadanía y ambientalismo. In: JELIN, Elizabeth (org). Mas allá de la nación: las escalas múltiples de los movimentos sociales. Buenos Aires: Libros del Zorzal.

HONORIO, Karen (2013). O significado da iniciativa para a integração da infraestrutura regional sul-americana (IIRSA) no regionalismo sul-americano (2000-2012): um estudo sobre a iniciativa e a participação do Brasil. 
Dissertação de mestrado. São Paulo. Programa de Pós-Graduação em Relações Internacionais San Tiago Dantas UNESP, UNICAMP, PUC/SP.

HOFFMANN, Andrea R., COUTINHO, Marcelo e KFOURI, Regina (2008). Indicadores e Análise Multidimensional do Processo de Integração do Cone Sul. Rev. Bras. Polít. Int. 51 (2): 98-116

HURRELL, Andrew (2007). On global order. Oxford university press.

JAEGER, Hans-Martin (2007). 'Global Civil Society' and the Political Depoliticization of Global Governance. International Political Sociology, Vol. 1 (3), p. 257-277.

KALDOR, Mary (2003). The idea of global civil society. International Affairs 79 (3), pp. 583-593.

KAY, Tamara (2005). "Labor transnationalism and global governance: the impact of NAFTA on transnational labor relationships in North America". American Journal of Sociology Vol. 111, n. 3, nov. 2005: 715-756

KAY, Tamara (2011). NAFTA and the politics of Labor Transnationalism. Cambridge University Press.

KEANE, John (2003). Global Civil Society? Cambridge University Press.

KECK, Margaret e SIKKINK, Kathryn (1998). Activists beyond borders. New York: Cornell University Press, 1998.

KEOHANE, Robert e NYE, Joseph (1971). Transnational relations and world politics. Harvard University Press.

KHAGRAM, Sanjeev, RIKER, James V. e SIKKINK, Kathryn (2002). "From Santiago to Seattle: transnational advocacy groups restructuring world 
politics". In: Restructuring world politics - transnational social movements, networks, and norms. University of Minnesota Press.

LAVALLE, Adrian G (2011a). Participação: valor, utilidade, efeitos e causa. In: Pires, R. R. (org.) Efetividade das instituições participativas no Brasil: estratégias de avaliação. Brasília: Ipea.

LAVALLE, Adrian; CASTELLO, Graziela; BICHIR, Renata (2004). Quando novos atores saem de cena. Continuidades e mudanças na centralidade dos movimentos sociais. Política e sociedade, no. 5, pp. 37-55.

LAVALLE, Adrian G. (2011) Após a participação: nota introdutória. Lua Nova, São Paulo, 84: 13-23.

LIMA, Maria Regina Soares (2000). Instituições democráticas e política exterior. Contexto Internacional, Rio de Janeiro, v. 22, n. 2, p. 265-303.

LIMA, Maria Regina Soares (2005). A política externa brasileira e os desafios da cooperação Sul-Sul. Revista Brasileira de Política Internacional, Brasília, v. 48, n. 1 , p. $24-59$.

LIMA, Maria Regina Soares (2007). "Decisões e indecisões: um balanço da política externa no primeiro governo do presidente Lula". Observatório Político Sul-Americano, Rio de Janeiro, janeiro.

LIMA, Maria Regina Soares (2013). Relações interamericanas: a nova agenda sul-americana e o Brasil. Lua Nova, São Paulo, 90: 167-201.

LIMA, Maria Regina Soares; HIRST, Monica (2006). Brazil as an Intermediate State and Regional Power: Action, Choice and Responsibilities. Journal of International Affairs, New York, v. 82, n. 1, p. 21-40.

LIMA, Maria Regina Soares; HIRST, Monica; PINHEIRO, Letícia (2010). Luzes e Sombras do Brasil Atual. Nueva Sociedad, número especial em 
português, pp. 22-41, 2010.

LIMA, Maria Regina Soares; SANTOS, Fabiano (2001). O Congresso e a política de comércio exterior. Lua Nova, São Paulo, n. 52, p. 121-149, 2001.

LIMA, Maria Regina, e COUTINHO, Marcelo V. (2007) "Uma versão estrutural do regionalismo". In: Eli Diniz (org.), "Globalização, Estado e Desenvolvimento", Rio de Janeiro, Editora FGV.

LIPSCHUTZ, Ronnie (1992). Reconstructing world polity: the emergence of global civil society. Millennium - Journal of International Studies 21, 389-420.

LIPSCHUTZ, Ronnie (2005). Global Civil Society and Global Governmentality: or, the search for politics and the state amidst the capillaries of social power. In: Barnett, M. and Duvall, R. (orgs.) Power in Global Governance. Cambridge: Cambridge University Press.

MALAMUD, Andres; GARDINI, Gian Luca (2012). Has Regionalism Peaked? The Latin American Quagmire and its Lessons. The International Spectator, Vol. 47, No. 1, March 2012, 116-133

MALAMUD, Andres; RODRIGUEZ, Juilio C (2013). Com um pé na região e outro no mundo: o dualismo crescente da política externa brasileira. Estudos Internacionais v. 1 n. 2 jul-dez 2013 p. 167-183

MALAMUD, Andres (2003). Presidentialism and Mercosur: a hidden cause for a succesfull experience. In: Laursen, F (ed.) Comparative regional integration: theoretical perspectives. Aldershot: Ashgate, 2003.

MARIANO, Karina P (2011). A participação das centrais sindicais no Mercosul (1991-2001). São Paulo: Cultura Acadêmica Editora. 
MARIANO, Marcelo; RAMANZINI, Haroldo (2012). Uma análise das limitações estruturais do Mercosul a partir das posições da política externa brasileira. Rev. Sociol. Polít., Curitiba, v. 20, n. 43, p. 23-41.

MARTÍNEZ-TORREZ, Maria Elena e ROSSET, Peter. La Vía Campesina: the birth and evolution of a transnational social movement. The Journal of Peasant Studies Vol. 37, No. 1, January 2010, 149-175

Mayntz, Renate (2004). Mechanisms in the Analysis of Social MacroPhenomena. Philosophy of the Social Sciences 34.

MCADAM, Doug, TARROW, Sidney, TILLY, Charles (2001). Dynamics of contention. Cambridge University Press

MCADAM, Doug, TARROW, Sidney, TILLY, Charles (2009). Para mapear o confronto político. Lua Nova. São Paulo, 76: pp. 11-48.

MEDEIROS, Carlos A. (2011) A dinamica da integracao produtiva asiática e os desafios à integracao produtiva no Mercosul. Analise Economica, Porto Alegre, ano 29, n.55.

MELLO, Flavia de Campos (1996). A nova agenda do comércio multilateral. Contexto Internacional, vol. 18, n.2.

MELLO, Flavia de Campos (2000). Regionalismo e inserção internacional: continuidade e transformação da política externa brasileira nos anos 90 . São Paulo, 2000. Tese de doutorado, Programa de Pós-Gradução em Ciência Política, Universidade de São Paulo.

MELLO, Flavia de Campos (2002). Política Externa Brasileira e os blocos internacionais. São Paulo em Perspectiva 16(1): 37-43. 
MILANI, Carlos; PINHEIRO, Leticia (2013). Política Externa Brasileira: os desafios de sua caracterização como política pública. Contexto internacional, Rio de Janeiro, vol. 35, no 1, p. 11-41.

MIDLEJ E SILVA, Suylan (2008). "Ganhamos a batalha, mas não a guerra”: A visão da Campanha Nacional contra a Alca sobre a não-assinatura do acordo. Tese de doutorado, Departamento de Sociologia, Universidade de Brasilia.

MORAVCSIK, Andrew e SCHIMMELFENNIG, Frank. Liberal intergovernamentalism. In: WIENER, Antje e DIEZ, Thomas. European Integration Theory. Oxford University Press, 2009.

O'BRIEN, Robert; GOETZ, Anne Marie; SCHOLTE, Jan Aart; WILLIAMS, Marc (2003). Contesting Global Governance: multilateral economic institutions and global social movements. Cambridge University Press.

PETERSON, John. Policy Networks. In: WIENER, Antje e DIEZ, Thomas. European Integration Theory. Oxford University Press, 2009.

PIANTA, Mario (2001). Parallel summits of global civil society. In: Anheier, Helmut, Marlies Glasius and Mary Kaldor (eds.) Global Civil Society 2001.Oxford University Press.

PIERSON, Paul. The path to European Integration: a historical institutionalist analysis. Comparative Political Studies, abril 1996, vol. 29 no. 2, pp. 123-163

PINHEIRO, Leticia. Os véus da transparência: política externa e democracia no Brasil. In: Câmara dos Deputados, Seminário Política Externa do Brasil para o século XXI, Brasília, 2003.

POLLACK, Mark. The new institutionalism and european integration. In: WIENER, Antje e DIEZ, Thomas. European Integration Theory. Oxford University Press, 2009. 
PRICE, Richard. Reversing the gun sights: transnational civil society targets land mines. International Organization vol. 52 (3), pp. 613-644, 1998.

REBRIP (2007). Texto de avaliação e debate. Disponível em http://www.inesc.org.br/biblioteca/textos/materias/rebrip-texto-de-avaliacao-edebate

REBRIP (2010). Propostas para a política externa do Brasil. Disponível em https://blogbrasilnomundo.files.wordpress.com/2012/07/avaliac3a7c3a3o-dapolc3adtica-externa-do-brasil-rebrip.pdf

RIELLA, A. (2002) Las Organizaciones rurales y el proceso de integración regional. Revista de Ciencias Sociales. Departamento de Sociología. Ano XV, n. 20.

RISSE, Thomas (1995). Bringing transnational relations back in. Cambridge University Press.

RISSE, Thomas; SIKKINK, Kathryn (1999) "The socialization of international human rights norms into domestic pratices: an introduction". In: Risse, Ropp e Sikkink (eds). The Power of Human Rights - International norms and domestic change. Cambridge University Press.

ROSENAU, James e CZEMPIEL, Ernst-Otto (orgs.) (2000). Governança sem Governo: ordem e transformação na política mundial. Brasília: Editora Universidade de Brasília, São Paulo: Imprensa Oficial do Estado.

SANCHEZ, Michelle R., SILVA, Elaini, CARDOSO, Evorah, SPÉCIE, Priscila (2006). Política externa como política pública: uma análise pela regulamentação constitucional brasileira (1967-1988). Revista Sociologia Política, Curitiba, 27, p. 125-143. 
SANCHEZ, Michele R. É possível pensar em sociedade civil no MERCOSUL? Cena Internacional, vol.9, no.1, 2007.

SARAIVA, Miriam G (2010). Brazilian Foreign Policy towards South America during the Lula Administration: Caught between South America and Mercosur. Revista Brasileira de Política Internacional, vol. 53, número especial, pp. 151168.

SARAIVA, Miriam G. e BRICEÑO, José R. Argentina, Brasil e Venezuela: as diferentes percepções sobre a construção do Mercosul. Rev. Bras. Polít. int. 52 (1): 149-166 [2009]

SCHMITTER, Phillipe e MALAMUD, Andres. La experiencia de integración europea y el potencial de integración del Mercosur. Desarrollo Económico, Vol. 46, No. 181 , pp. 3-31

SCHMITTER, Phillipe e NIEMANN, Arne. Neofunctionalism. In: WIENER, Antje e DIEZ, Thomas. European Integration Theory. Oxford University Press, 2009.

SCHOLTE, Jan Aart (2002). "Civil Society and Democracy in Global Governance”. Global Governance 8, pp. 281-304, 2002.

SENDING, Ole Jacob e NEUMANN, Iver. Governance to Governmentality: Analyzing NGOs, States, and Power. International Studies Quarterly 50, 651$672,2006$.

SERBIN, Andrés. Atuando sozinho? Governos, sociedade civil e regionalismo na América do Sul. Lua Nova, São Paulo, 90: 297-327

SHAW, Martin (1994). "Civil Society and Global Politics: Beyond a Social Movements Approach". Millenium: Journal of International Studies vol.23 (3), p.647-667 
SIKKINK, Kathryn. La dimension transnacional de los movimientos sociais. In: JELIN, Elizabeth (org). Mas allá de la nación: las escalas múltiples de los movimentos sociales. Buenos Aires: Libros del Zorzal.

SIKKINK, Kathryn (2005). "Patterns of dynamics multilevel governance and the insider-outsider coalition". In: Della Porta e Tarrow, Transnational protest and global activism. Rowman \& Littlefield Publishers.

SIKKINK, Kathryn; KHAGRAM, Sanjeev; RIKER, James V. Restructuring world politics - transnational social movements, networks, and norms. University of Minnesota Press, 2002. Pag. 3-23

SMITH, William; KORZENIEWICZ, Roberto P. (2006). El movimiento doble: actores insiders y outsiders en la emergencia de una sociedad civil transnacional en las Américas. Colombia Internacional 63, pp. 40-69.

STUART, Ana Maria (1999). A sociedade civil na integração: moviementos sociais e organizações sindicais. In: CHALOULT, Yves; ALMEIDA, Paulo R (orgs). Mercosul, Nafta e ALCA: a dimensão social. São Paulo: LTr

STUART, Ana Maria. Regionalismo e democracia: uma construção possível. Tese de doutorado. Universidade de São Paulo, 2002.

TARROW, Sidney. Power in movement - social movements and contentious politics. Cambridge: Cambridge University Press, 1998.

TARROW, Sidney. The New Transnational Activism. Cambridge University Press, 2005.

TARROW, Sidney. Outsiders inside e insiders outside: entre a ação pública nacional e transnacional em prol dos direitos humanos. Caderno $\mathrm{CRH}$, Salvador, vol. 22, n.55, 2009 
TILLY, Charles. From mobilization to revolution. Newberry Award Records, 1978.

VADELL, Javier. (2011), "A China na América do Sul e as Implicações Geopolíticas do Consenso do Pacífico". Revista de Sociologia e Política, vol. 19, no suplementar, pp. 57-79.

VALDÉS, Teresa (2003). El Mercosur y el movimiento de mujeres: un espacio para ampliación de ciudadanía? In: JELIN, Elizabeth (org). Mas allá de la nación: las escalas múltiples de los movimentos sociales. Buenos Aires: Libros del Zorzal.

VAZ, Alcides C. (2002). Cooperação, integração e processo negociador: a construção do Mercosul. Brasília: Instituto Brasileiro de Relações Internacionais.

VAZQUEZ, Mariana (2007). Los escenarios de participación social en el Mercosur. Trabalho apresentado no Congresso comemorativo de cinquenta anos da FLACSO, em Quito, outubro de 2007.

VÁZQUEZ, Mariana. Mercosur social. Cambio político y nueva identidad para el proceso de integración regional en América del Sur. In: Caetano, G (org.) Mercosur 20 años. Montevideo: CEFIR, 2011

VENTURA, Deisy; CAETANO, Gerardo; VAZQUEZ, Mariana. Reforma institucional del Mercosur - analisis de un reto. In: La reforma institucional del Mercosur: del diagnostico a las propuestas. Montevideo: CEFIR, 2009.

VENTURA, Deisy; MIOLA, lagê Zendron (2009). Os efeitos da transnacionalização sobre a governança regional. Contexto internacional, Rio de Janeiro, vol.31, n.3, 
VENTURA, Deisy; ONUKI, Janina; MEDEIROS, Marcelo et alli (2012). Internalização das normas do MERCOSUL. Série Pensando o Direito, vol. 45. Brasília: Ministério da Justiça.

VIGEVANI, Tullo. Globalização e regionalização do Mercosul: a intervenção dos sindicatos no processo de integração. Caderno CEDEC (São Paulo), São Paulo: Cedec, n. 53, p. 1-57, 1996.

VIGEVANI, Tullo; MARIANO, Karina P. (1999). Estratégias e alianças entre os atores sociais. In: CHALOULT, Yves; ALMEIDA, Paulo R (orgs). Mercosul, Nafta e ALCA: a dimensão social. São Paulo: LTr

VIGEVANI, Tullo; OLIVEIRA, Marcelo; CINTRA, Marcos (2003). Política externa no período FHC: a busca de autonomia pela integração. Tempo social vol.15 no.2 São Paulo Nov.

VIGEVANI, Tullo; CEPALUNI, Gabriel (2007). A política externa de Lula da Silva: a estratégia de autonomia pela diversificação. Contexto Internacional, Rio de Janeiro, v. 29, n. 2, p. 273-335, jul.-dez.

VIGEVANI, Tullo et el (2008). O papel da integração regional para o Brasil: universalismo, soberania e percepção das elites. Revista Brasileira de Politica Internacional, Brasília, v. 51, n. 1, p. 5-27.

VIGEVANI, Tullo. \& RAMANZINI JÚNIOR, Haroldo (2009). Brasil en el centro de la integración. Los cambios internacionales y su influencia en la percepción brasileña de la integración. Nueva Sociedad, Buenos Aires, n. 219, p. 76-96, ene.

VIGEVANI, Tullo e RAMANZINI, Haroldo. Autonomia e integração regional no contexto do Mercosul. Uma análise considerando a posição do Brasil. OSAL (Buenos Aires: CLACSO) Año XI, no. 27. 
VIGEVANI, Tullo; RAMANZINI JR., Haroldo. (2014). Autonomia, Integração Regional e Política Externa Brasileira: Mercosul e Unasul. DADOS - Revista de Ciências Sociais, Rio de Janeiro, vol. 57, no 2, 2014, pp. 517 a 552.

VON BÜLLOW, Marisa (2010). Building transnational networks. Cambrigde University Press.

WALKER, R.B.J. Inside/outside: international relations as political theory. NY: Cambridge university press, 1993.

WALKER, R.B.J. Social Movements/World Politics. Millennium - Journal of International Studies vol.23 (3), pp.669-700, 1994.

WiMMER, Andreas; GLICK-SCHILLER, Nina (2002). Methodological nationalism and beyond: nation-state building, migration and the social sciences. Global Networks 2, 4 